\title{
Preliminary Design Manual for a Geothermal Demonstration Plant at Heber, California
}

\author{
ER-670 \\ Research Project 580 \\ Topical Report, February 1978

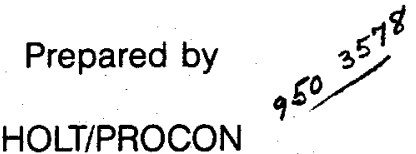 \\ (A Joint Venture of The Ben Holt Co. and Procon Incorporated) \\ 201 South Lake Avenue \\ Pasadena, California 91101 \\ Principal Investigators \\ Ben Holt \\ Edward L. Ghormley
}

\section{Prepared for}

Electric Power Research Institute

3412 Hillview Avenue

Palo Alto, California 94304

EPRI Project Manager

Vasel W. Roberts

Fossil Fuel and Advanced Systems Division 


\section{DISCLAIMER}

This report was prepared as an account of work sponsored by an agency of the United States Government. Neither the United States Government nor any agency Thereof, nor any of their employees, makes any warranty, express or implied, or assumes any legal liability or responsibility for the accuracy, completeness, or usefulness of any information, apparatus, product, or process disclosed, or represents that its use would not infringe privately owned rights. Reference herein to any specific commercial product, process, or service by trade name, trademark, manufacturer, or otherwise does not necessarily constitute or imply its endorsement, recommendation, or favoring by the United States Government or any agency thereof. The views and opinions of authors expressed herein do not necessarily state or reflect those of the United States Government or any agency thereof. 


\section{DISCLAIMER}

Portions of this document may be illegible in electronic image products. Images are produced from the best available original document. 
LEGAL NOTICE

This report was prepared by Ho1t/Procon (a Joint Venture of The Ben Holt Co. and Procon Incorporated), as an account of work sponsored by the Electric Power Research Institute, Inc. (EPRI). Neither EPRI, members of EPRI, Holt/Procon, nor any person acting on behalf of either: (a) makes any warranty or representation, express or implied, with respect to the accuracy, completeness, or usefulness of the information contained in this report, or that the use of any information, apparatus, method, or process disclosed in this report may not infringe privately owned rights; or (b) assumes any liabilities with respect to the use of, or for damages resulting from the use of, any information, apparatus, method, or process disclosed in this report. 
This report presents a preliminary design of a 50 MWe Geothermal Demonstration Plant for Heber, California. The report includes a site description, design basis, process design, trade-off studies to optimize plant operations, and an economic analysis of the plant.

The plant design provides flow diagrams and equipment specifications for the energy conversion system, the cooling water system, the plant and instrument air system, the flare system, the firewater system, the electrical system, the piping system, instruments and controls, and buildings and structures. 
U 
TABLE OF CONTENTS

Section

Page

1 SUMMARY

$1-1$

2 INTRODUCTION $2-1$

3 DEVELOPMENT OF DESIGN $3-1$

SITE DESCRIPTION $3-1$

DESIGN BASIS 3-3

PROCESS DESIGN $3-5$

TRADE-OFF STUDIES $3-10$

ECONOMIC ANALYSIS $3-17$

$\begin{array}{ll}\text { FIGURE 3-1 } & \text { PERFORMANCE OF VARIOUS GEOTHERMAL } \\ & \text { BINARY CYCLES }\end{array}$

FIGURE 3-2 ALTERNATIVE PUMP CONFIGURATIONS 3-21

FIGURE $3-3$ ESTIMATE SUMMARY SHEET $\quad 3-22$

TABLE 3-1 EFFECT OF BRINE/HYDROCARBON EXCHANGER PINCH POINT ON POWER COST $3-23$

TABLE 3-2 EFFECT OF CONDENSER LOG MEAN TEMPERATURE DIFFERENCE ON POWER COST 3-24

TABLE 3-3 EFFECT OF COOLING TOWER APPROACH TO WET BULB TEMPERATURE ON POWER COST 3-25

TABLE 3-4 EFFECT OF COOLING TOWER APPROACH TO WET BULB TEMPERATURE ON POWER COST $\quad 3-26$

TABLE 3-5 EFFECT OF COOLING WATER TEMPERATURE RISE ON POWER COST

TABLE 3-6 HYDROCARBON CIRCULATION PUMP STUDY 3-28

DRAWING NO. 7523-D-3260, REV. A - BINARY PROCESS FLOW DIAGRAM GEOTHERMAL DEMONSTRATION PLANT - START OF RUN

DRAWING NO, 7523-D-3275, REV. A - BINARY PROCESS FLOW DIAGRAM GEOTHERMAL DEMONSTRATION PLANT MIDDLE OF RUN 
TABLE OF CONTENTS

Section

Page

4 DESCRIPTION OF FACILITIES 4-1

PLANT LAYOUT $\quad 4-2$

ENERGY CONVERSION SYSTEM $4-3$

COOLING WATER SYSTEM 4-5

PLANT AND INSTRUMENT AIR SYSTEM 4-6

FLARE SYSTEM $\quad$ 4-7

FIRE WATER SYSTEM $\quad$ 4-8

ELECTRICAL SYSTEM $\quad 4-9$

PIPING 4-9

INSTRUMENTATION AND CONTROL 4-10

BUILDINGS AND STRUCTURES 4-12

DRAWING NO. 7523-E-3242, REV. C - BINARY PROCESS GEOTHERMAL DEMONSTRATION PLANT PLOT PLAN 4-15

DRAWING NO. 7523-E-3215, REV. C - BINARY PROCESS P\&ID GEOTHERMAL DEMONSTRATION PLANT, HEBER, CALIFORNIA

DRAWING NO. 7523-E-3246, REV. C - BINARY PROCESS COOLING WATER P\&ID GEOTHERMAL DEMONSTRATION PLANT, HEBER, CALIFORNIA

DRAWING NO. 7523-E-3221, REV. C - INSTRUMENT \& PLANT AIR PGID GEOTHERMAL DEMONSTRATION PLANT

DRAWING NO. 7523-D-3222, REV. B - FLARE SYSTEM P\&ID GEOTHERMAL DEMONSTRATION PLANT, HEBER, CALIFORNIA

DRAWING NO. 7523-D-3601, REV. B - BINARY PROCESS GEOTHERMAL DEMONSTRATION PLANT MAIN SINGLE LINE DIAGRAM, HEBER, CALIFORNIA

DRAWING NO. 7523-D-3602, REV. B - BINARY PROCESS GEOTHERMAL DEMONSTRATION PLANT, $4160 \mathrm{~V}$. SINGLE LINE DIAGRAM, HEBER, CALIFORNIA

DRAWING NO. 7523-D-3603, REV. B - BINARY PROCESS GEOTHERMAL DEMONSTRATION PLANT "MCC-A" SINGLE LINE DIAGRAM, HEBER, CALIFORNIA 
4 (Cont.) DRAWING No. 7523-D-3604, REV. B - BINARY PROCESS GEOTHERMAL DEMONSTRATION PLANT "MCC-B" SINGLE LINE DIAGRAM, HEBER, CALIFORNIA

DRAWING NO. 7523-E-3261, REV. B - BINARY PROCESS GEOTHERMAL DEMONSTRATION PLANT PIPING AREA LOCATION PLOT PLAN

DRAWING NO. 7523-E-3262, REV. B - BINARY PROCESS GEOTHERMAL DEMONSTRATION PLANT AREA "A" PIPING PLAN, PUMP PIT \& COOLING TOWER

DRAWING NO. 7523-E-3263, REV. B - BINARY PROCESS GEOTHERMAL DEMONSTRATION PLANT AREA "B" PIF ING PLAN, GRADE TO ELEVATION 18'-0"

DRAWING NO. 75:3-E-3264, REV. B - BINARY PROCESS GEOTHERMAL DEMONSTRATION PLANT AREA "B" PIPING PLAN, ELEVATION 18'-0" AND ABOVE

DRAWING NO. 7523-E-3265, REV. B - BINARY PROCESS GEOTHERMAL DEMONSTRATION PLANT AREA "D" PIPING PLAN

DRAWING NO. 7523-E-3268, REV. B - BINARY PROCESS GEOTHERMAL DEMONSTRATION PLANT AREA "B" PIPING SECTIONS, SEC. "A-A"

DRAWING NO. 7523-E-3269, REV. B - BINARY PROCESS GEOTHERMAL DEMONSTRATION PLANT AREA " $C$ " PLAN, PIPING SECTIONS

DRAWING NO. 7523-D-3258, REV. A - PIPING STANDARD SYMBOLS FOR PROCESS FLOW DIAGRAMS AND PIPING AND INSTRUMENT DIAGRAMS

5 EQUIPMENT SPECIFICATIONS

EQUIPMENT LIST

VESSELS

HEAT EXCHANGERS

PUMPS

COOLING TOWER

COMPRESSOR

TURBINE/GENERATOR 


\section{Section 1}

\section{SUMMARY}

In October 1975, the Electric Power Research Institute authorized Holt/Procon to make a feasibility study for a low-salinity hydrothermal demonstration plant. The objective of the first part of the study (Part A) was to make a technical, economic and environmental analysis of the proposed project and, if supported by the findings, to recommend a site for the construction of a $25 \mathrm{MWe}$ to $50 \mathrm{MWe}$ geothermal power plant and a process upon which to base the design. Part A was completed in April 1976, with the following conclusions and recommendations :

- The geothermal reservoir at Heber, California is technically economically, and environmentally feasible for location of the geothermal demonstration plant.

- The binary conversion process is technically, economically, and environmentally feasible for producing electric power using fluid from a hydrothermal reservoir. At the Heber site this process converts geothermal energy into electrical energy at a lower cost than either the flashed steam process or the hybrid process.

- A 50 MWe binary conversion plant at Heber produces electric power at a cost that is comparable with other new sources of power. A smaller plant would experience higher operating costs which would reduce the profitability of the plant operation.

Following completion of Part A, a preliminary design study of a 50 MWe binary conversion plant at Heber was initiated and is presented herein.

Chevron 0il Company (the field operator) predicts that the reservoir temperature will decline from an initial temperature of $182 \mathrm{C}(360 \mathrm{~F})$ to a fina1 temperature of $162 \mathrm{C}(325 \mathrm{~F})$ over a period of 25 years at a production rate of 200 MWe. Accordingly, the plant has been designed so that it may readily and economically be modified to accommodate the increased brine requirement and increased working fluid circulation at the lower reservoir temperature while still maintaining a net output of 50 MWe. 
A working fluid containing 20 percent isopentane and 80 percent isobutane was selected for the initial operating conditions. When the fluid temperature declines to $174 \mathrm{C}$ (345 F), the working fluid is changed to a hydrocarbon mixture containing 10 percent propane and 90 percent isobutane. This fluid will operate efficiently in the temperature range from $174 \mathrm{C}$ (345 F) to $162 \mathrm{C}$ (325 F).

Trade-off studies were performed to determine optimum design conditions for the plant. The following conclusions were reached:

- Operational economy is favored by a low pinch temperature between the reservoir fluid and the working fluid.

- Operational economy and the cost of energy produced is only slightly affected by the approach temperature between the cooling water and the ambient wet bulb temperature.

- The cost of energy is affected by cooling water temperature rise. An intermediate temperature rise of about $11.7 \mathrm{C}(21 \mathrm{~F})$ gives the lowest cost of energy.

- A study was made of the hydrocarbon circulating pumps to determine whether turbines or electric motors should be used for motive power. It was concluded that electric motors should be used to drive six vertical centrifugal pumps.

An updated cost estimate of the demonstration plant was prepared. The estimated cost of the plant is $\$ 29,634,000$ or $\$ 592$ per $\mathrm{kwh}$. This cost is slightly higher than the cost presented in the base case for Heber, California reported previously $(\$ 28,500,000)$, due in part to design changes resulting from the trade-off studies and in part to increased precision of the estimating procedure.

The cost of power delivered to a load center was calculated to be 35.84 $\mathrm{mills} / \mathrm{kwh}$ which is a slight increase over the $35.33 \mathrm{mil1s} / \mathrm{kwh}$ previously calculated for the base case.

We have defined the plant baseline configuration by the preparation of process flow diagrams for the initial plant operating condition and the 
mid-range plant operating condition. Piping and instrumentation diagrams have been revised and expanded to reflect the improved plant design. Preliminary piping layout drawings have been prepared and, as a result of these studies, the plot plan has been enlarged to provide space for future equipment additions and the large interconnecting pipelines.

Electrical single-line drawings have been revised to reflect the latest plant configuration. Equipment specifications have been modifed to meet the requirements of the new hydrocarbon mixture working fluid. Preliminary layouts and specifications have been prepared for the buildings and structures at the site.

Material and installation specifications have been prepared for piping, electrical equipment, buildings, and standard construction procedures.

An implementation plan for the design and construction of the plant has been prepared in a separate volume which includes:

- A schedule for applications and permits

- A schedule for engineering and construction

- A critical path schedule showing the time sequence of the critical function affecting plant completion

The preliminary environmental assessment was revised and updated to show the effect of construction of a single 50 MWe geothermal plant, and the effect of 4000 MWe of geothermal capacity would affect the Imperial Valley, and the Heber area in particular. The environmental assessment is presented in separate volumes. 
Section 2

INTRODUCTION

The subject feasibility study for a low salinity hydrothermal demonstration plant consists of a series of tasks divided in two parts. Part A, entitled Feasibility Analysis Tasks, was completed at the end of April, 1976 and submitted in a series of draft reports listed as follows:

- "Comparison of Hydrothermal Reservoirs in the Western United States"

- "Reservoir Engineering and Aspects of Geothermal Site Selection at Heber, California and Valles Caldera, New Mexico"

- "Energy Conversion and Economics for Geothermal Power Generation at Heber, California; Valles Caldera, New Mexico; and Raft River, Idaho - Case Studies"

- "Preliminary Environmental Assessments of Geothermal Power Generation at Heber, California"!

- "Geotechnical Environmental Aspects of Geothermal Power Generation at Heber, California"

- "Socioeconomic Environmental Aspects of Geothermal Power Generation at Heber, California"

The conclusions reached as a result of the Part A studies were that the Heber reservoir in the Imperial Valley is the preferred location for a demonstration plant, that the binary cycle is the preferred process, that a $50 \mathrm{MWe}$ plant is the preferred size, and finally that the proposed project is feasible from a geotechnical, technical and environmental standpoint.

Accordingly, EPRI authorized us to proceed with Part B of the project which includes the following 1isted tasks:

- TASK B-1 - Preliminary (Conceptual) Design of a 50 MWe binary cycle plant at Heber

- TASK B-2 - Specifications

- TASK B-3 - Cost Estimate

- TASK B-4 - Implementation Plan

- TASK B-5 - Environmental Assessment 
This manual presents the results of Tasks 1, 2 and 3 .

The response to Task B-4 is contained in a separate report entitled "Implementation Plan for a Geothermal Demonstration Plant at Heber, California."

The response to Task B-5 is a separate report in four volumes:

- Volume I - Preliminary Environmental Assessments of Geothermal Power Generation at Heber, California

- Volume II - Geotechnical Environmental Aspects of Geothermal Power Generation at Heber, California

- Volume III - Socioeconomic Environmental Aspects of Geothermal Power Generation at Heber, California

- Volume IV - Appendices

Draft reports for Task B-5 were submitted in April. These reports have been finalized as a part of our Part B tasks.

In preparing the Preliminary Design Manual we have focused our attention on the power generation plant and have left a similar design effort covering the field installation to a later date.

This manual contains the following technical reports required by EPRI under Task B-1:

- Trade-off studies

- Baseline configuration description

- Plant requirements document

- Equipment specifications

- Capital cost estimate

- Long lead items procurement specifications 
Section 3

DEVELOPMENT OF DESIGN

In Part A, previously reported, conceptual designs were prepared by three processes at three sites. These designs and the accompanying cost estimates were prepared in sufficient detail to permit a realistic comparison of sites and processes.

Following the selection of a site (Heber) and a process (binary) we focused our attention on optimization studies leading to the preliminary design presented herein.

\section{SITE DESCRIPTION}

\section{Location}

The Heber geothermal field is located at the southern end of Imperial County, California, approximately $6 \mathrm{~km}$ ( 4 miles) north of the United States/Mexico border, $8 \mathrm{~km}$ ( 5 miles) southeast of the City of E1 Centro, and $2 \mathrm{~km}$ ( $1 \mathrm{mile})$ south of the City of Heber. Maps showing the field location are presented in a separate report entitled "Preliminary Environmental Assessments of Geothermal Power Generation at Heber, California." An exact site location will be selected during the final design phase of the work.

The geothermal-electric energy conversion plant will occupy approximately $24,000 \mathrm{M}^{2}$ (6 acres). A plot plan for the plant site is contained in section 4 of this report.

The production and injection wells will be drilled on approximately $0.6 \mathrm{~km}$ $(0.4 \mathrm{mile})$ and $3.2 \mathrm{~km}$ ( $2 \mathrm{miles})$ radii from the center of the reservoir. The plant will be located adjacent to the production wells. The exhausted reservoir fluid will be returned to the injection wells in a buried pipeline. 


\section{Climate}

The climate of the Heber area, like the entire Imperial Valley, is hot and dry. Annual average precipitation is $7.1 \mathrm{~cm}(2.8$ inches), and average daily Summer dry bulb temperature exceeds $37 \mathrm{C}(100 \mathrm{~F})$. The average minimum Winter temperature is $-2 \mathrm{C}(28 \mathrm{~F})$.

Prevailing winds are generally below $7 \mathrm{~m} / \mathrm{sec}$. (15 $\mathrm{miles} / \mathrm{hour}$ ) and from the west. Average daily relative humidity ranges between 20 and 30 percent.

\section{Topography}

The plant site is on generally level agricultural land approximately 5 feet below sea level. The terrain slopes gently downward to the north toward the Salton Sea. Drainage is provided by the New and Alamo Rivers and an extensive network of manmade agricultural drains.

\section{Geology and Soils}

The upper $15 \mathrm{~cm}$ ( 6 inches) of soil in cultivated areas is highly organic, with underlying soil of fine textured clays which are expansive when wetted. The allowable soil bearing pressure is $7,200 \mathrm{~kg} / \mathrm{m}^{2}$ (1,500 psf).

Imperial County is located within Seismic Zone 3; for which a design acceleration of $0.25 \mathrm{~g}$ is recommended by the Uniform Building Code. However, because of the proximity of Heber to numerous active faults, a design acceleration of $0.375 \mathrm{~g}$ is recommended for plant design.

\section{Water Supply}

The Central Main Canal, and various subsidiary irrigation canals belonging to the Imperial Irrigation District, pass within about $2 \mathrm{~km}$ ( 1 mile) of the site. Water for plant cooling and potable uses will be drawn from these canals. Cooling tower blowdown water will be discharged to the agricultural drain system as is currently being done at the San Diego Gas \& Electric Company geothermal facility near Niland, Imperial County, California. 
Sanitary wastewater will be treated in a septic tank and dispersed through a tile drain field.

\section{Access}

A light-duty paved road runs north/south along the east boundary of the plant site. Also, a Southern Pacific railroad track running north-northwest/southsoutheast lies within $1 \mathrm{~km}$ east of the plant site. Rail sidings presently exist at Heber, $2 \mathrm{~km}$ to the north.

\section{Transmission Lines}

The Imperial Irrigation District plans to build a $33 \mathrm{kv}$ substation near Heber, about $2 \mathrm{~km}$ north of the plant site. A $33 \mathrm{kv}$ transmission line would be built by Imperial Irrigation District from the plant substation to the substation at Heber to carry electrical energy in and out of the geothermal demonstration plant.

\section{DESIGN BASIS}

The previously reported feasibility studies showed that it would be technically and economically feasible to build a demonstration plant at Heber, California, using the binary conversion process to generate electric power. It was decided that the plant should be built in the range of $50 \mathrm{MWe}$ electrical capacity in order that the cost of power produced from the plant would be economically competitive with alternative methods of generating electric power.

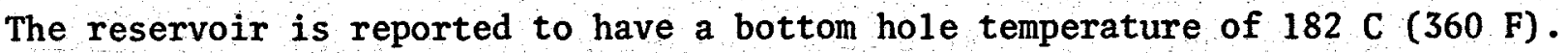
Chevron 0il Company has predicted that the temperature of the brine would degrade slowly from this initial temperature to a temperature of $163 \mathrm{C}$ (325 F) after 25 years' operation of the reservoir at a gross power production rate of $200 \mathrm{MWe}$. This temperature drop of the reservoir fluid requires that the plant be designed so that its circulating systems can be expanded to maintain a constant power production rate over the life of the reservoir. 
The reservoir fluid has a total dissolved solids content of about 15,000 ppm. No accurate analysis has been made to determine the quantity of noncondensable gases in the reservoir fluid, but a program is currently in progress to determine the quantity and analysis of such gases if they are present. The field tests conducted by Chevron indicate that the noncondensables (if any) will remain in solution in the hot water and will be reinjected with the hot water back to the reservoir.

Heat exchanger tests performed by the San Diego Gas \& Electric Company at Heber showed that the salts present in the fluid form scale at a negligible rate at temperatures above $132 \mathrm{C}(270 \mathrm{~F})$, but below that temperature fouling occurs at an increased rate. From their data we estimated the following tubeside fouling factors which were used in the design of brine/working fluid heat exchangers :

\begin{tabular}{rrrr} 
Temperature, $C$ & & Temperature, F & Fouling Factor \\
\cline { 3 - 4 } 176 to 132 & 350 to 270 & .0001 \\
132 to 80 & 270 to 176 & .0011 \\
80 to 65 & 176 to 148 & .0033
\end{tabular}

These factors are tentative in that the results of a 22-day test have been extrapolated to predict a fouling factor suitable for one year's operation.

A 2,000-hour test program is currently in progress to confirm these figures and to obtain additional corrosion data. This work is being funded by EPRI and the State Energy Commission.

The previous exchanger tests were conducted using titanium, $90 \%$ cupro nickel and mild steel exchanger tubes. No corrosion was observed on the titanium tubes after 560 hours' exposure; some corrosion occurred to the cupro nickel tubes after 200 hours' testing; and slight pitting and surface decarbonization were observed on the carbon steel tubes after 560 hours of testing. It is possible that the slight corrosion of the steel tubes had occurred prior to the test program. Chevron has indicated that corrosion during their test work was negligible. Accordingly, we have specified the use of steel in all 
equipment exposed to brine. A final decision on materials will be made on the basis of the test program currently in progress.

Summer time dry bulb ambient temperatures vary up to $49 \mathrm{C}(120 \mathrm{~F})$. One percent of the time during the summer months, the wet bulb temperature reaches or exceeds $27 \mathrm{C}(80 \mathrm{~F})$. This wet bulb temperature was used for design.

\section{PROCESS DESIGN}

The development of a process design for a geothermal project is an evolutionary one. Initially the problem is loosely specified and there are numerous alternatives. As the project proceeds, more data are made available and alternatives are eliminated so that the design can be refined. The final design is a product that is achieved by successive improvements in the original design premise.

Preliminary geological data and modeling indicate that if the reservoir is produced at a rate of $200 \mathrm{MWe}$, the temperature is expected to decline uniformly over a period of about 25 years to a value of about $163 \mathrm{C} \mathrm{(325} \mathrm{F).} \mathrm{A}$ single plant design would not operate efficiently at both $182 \mathrm{C}(360 \mathrm{~F})$ and $163 \mathrm{C}(325 \mathrm{~F})$. The task, therefore, was to find a sequence of processes which would allow generation of the required electrical power over the desired brine temperature range from minimum modification to the original plant configuration. A large number of configurations were studied to this end. A wide spectrum of aliphatic hydrocarbon fluids including pure hydrocarbons and mixtures of two and three hydrocarbons were analyzed at various temperatures and pressures. A number of otherwise promising cycles were dropped from consideration when it was discovered that expansion of the fluid passed into the two-phase region, making the successful operation of present-day turbines doubtful. Other good cycles were bypassed because they would have necessitated major changes in the plant equipment or would not have efficiently utilized equipment available from an earlier stage in the plant lifetime. 
Thermodynamic Cycle Studies

The initial phases of the process design are reported in detail in the "Thermodynamic Cycle Analysis" section of "Energy Conversion and Economics for Geothermal Power Generation at Heber, California; Valles Caldera, New Mexico; and Raft River, Idaho - Case Studies" (Energy Conversion Study). The selection of the final working fluids for Heber was done in the same general manner as the initial screening study, described in the Energy Conversion Study.

The next phase of the process engineering consisted of:

- Studying fluids not included in the initial study

- Establishing the economic sensitivity of the major design parameters

- Analyzing the behavior of the various processes at mid-run "off-design" conditions

- Reviewing the most promising cycles and screening out those that presented serious technical or equipment problems

A class of working fluids not studied in the initial phase is composed of three hydrocarbon species. Several combinations of propane, isobutane and isopentane were analyzed, but did not prove to be superior to the twocomponent fluids.

Figure 3-1 provides a summary of the procedures which led to the selection of the final process design. This figure shows graphically the relationship between reservoir temperature and net power output for a number of working fluid compositions. Each of these curves has been optimized with respect to turbine inlet pressure and temperature.

Curve A represents the thermodynamic performance of the best fluid for the start-of-run conditions as a result of the initial study for the Energy Conversion Study. This cycle is favored at $182 \mathrm{C} \mathrm{(360} \mathrm{F)} \mathrm{but} \mathrm{the} \mathrm{performance}$ drops off sharply at lower temperatures. Likewise, Curve B shows the performance of the preferred end-of-run case in the Energy Conversion Study. 
This cycle, which is optimum for $163 \mathrm{C}(325 \mathrm{~F})$, performs poorly at higher temperatures. Curve $\mathrm{C}$ shows the performance of the best three-component cycle that we studied. It shows significantly lower performance than most of the two-component cycles. Curve D illustrates the performance of the best case we found in our study. However, it was rejected because the expansion would have precipitated excessive liquid in the turbine. (Parenthetically, it appears that the development of a turbine capable of operating in the twophase region without loss of efficiency is a worthwhile objective.)

The process design of plants for mid-run and "off design" conditions involves a great deal of complexity. First, the design must be optimum at the given brine temperature of interest. Second, the process must perform well at brine temperatures on either side of the optimum. Third, the cycle must "mesh" with cycles on either side. This means that flow rates, operating pressures, heat exchanger surface areas, etc. must be consistent so that in operating a geothermal plant, a smooth transition can be made from one process to the next. It was found that the entire desired operating range from $182 \mathrm{C}(360 \mathrm{~F})$ to $163 \mathrm{C}(325 \mathrm{~F})$ could be accommodated by two cycles with a switchover occurring when the brine was at $174 \mathrm{C}$ (345 F).

Curves $E$ and $F$ show the performance of the two cycles for the start-of-run and end-of-run designs which were finally adopted. The discontinuity of these curves at $174 \mathrm{C}(345 \mathrm{~F})$ is an artifact of the assumptions used in the analysis. In actual practice, the heat exchange surface requirements for the start-of-run case actually decrease with dropping brine temperature due to a favorable trend in the $10 \mathrm{~g}$-mean temperature difference (LMTD). Since the heat exchangers will not be reduced in size from the initial installation, there exists, at the lower temperatures, an excess of heat transfer surface. This will allow a more effective utilization of the brine which will allow a smooth transition from Curve E to Curve F.

The economic sensitivity of such design parameters as heat exchanger temperature approach was also investigated. These studies are described in detail in the section of this report dealing with the trade-off studies. 


\section{Process Flow Diagrams}

Drawing 7523-D-3260 is a process flow diagram for this plant at the start-ofrun conditions. The process flow diagram shows principal items of equipment and presents heat and material balances for the hydrocarbon working fluid and reservoir fluid.

A summary of the pertinent design data is as follows:

$\begin{array}{ll}\begin{array}{l}\text { Reservoir Fluid } \\ \text { Temperature } \\ \text { Flow Rate }\end{array} & 182 \mathrm{C}(360 \mathrm{~F}) \\ & 3.05 \times 10^{6} \mathrm{~kg} / \mathrm{hr}\left(6.72 \times 10^{6} \mathrm{lbs} / \mathrm{hr}\right) \\ \begin{array}{l}\text { Hydrocarbon Working Fluid } \\ \quad \begin{array}{l}\text { Composition } \\ \text { (mole basis) }\end{array}\end{array} & 80 \% \text { isobutane, } 20 \% \text { isopentane } \\ \begin{array}{l}\text { Flow Rate } \\ \text { Gross Generator Output }\end{array} & 3.49 \times 10^{6} \mathrm{~kg} / \mathrm{hr}\left(7.69 \times 10^{6} \mathrm{lbs} / \mathrm{hr}\right) \\ \begin{array}{l}\text { In-plant Load } \\ \text { Net Power Output }\end{array} & 61 \mathrm{MWe} \\ & \underline{11} \mathrm{MWe} \\ & 50 \mathrm{MWe}\end{array}$

The hydrocarbon liquid is preheated and vaporized by heat exchange with the brine reservoir fluid at a pressure of $3447 \mathrm{kPa}$ (500 psia) and to a temperature of $146 \mathrm{C}$ (295 F). The super-critical vapor drives an expansion turbine connected to an electrical generator. Exhaust vapor from the turbine is condensed in a group of water-cooled exchangers and collected in accumulators. The liquid hydrocarbon is pumped at elevated pressure back through the heat exchangers, completing the cycle.

As the geothermal reservoir is produced continuously for a number of years, the brine temperature will decrease. Above $174 \mathrm{C}$ (345 F) brine flow to the plant will be increased as brine temperature drops, but the working fluid cycle will remain unchanged. At about $174 \mathrm{C}$ (345 F) economic considerations require a change in working fluid composition and other design parameters. 
We selected a hydrocarbon mixture consisting of $10 \%$ propane and $90 \%$ isobutane for the middle-of-run condition. Drawing 7523-D-3275 is a process flow diagram showing the operation of the plant using the middle-of-run fluid. Pertinent design data are as follows:

\begin{tabular}{ll}
$\begin{array}{l}\text { Reservoir Fluid } \\
\text { Temperature } \\
\text { Flow Rate }\end{array}$ & $174 \mathrm{C}(345 \mathrm{~F})$ \\
& $3.48 \times 10^{6} \mathrm{~kg} / \mathrm{hr}$ \\
Hydrocarbon Working Fluid & $\left(7.66 \times 10^{6} \mathrm{lbs} / \mathrm{hr}\right)$ \\
Composition & \\
(Mole basis) & $90 \%$ isobutane \\
Flow Rate & $10 \% \mathrm{propane}$ \\
Gross Generator Output & $4.09 \times 10^{6} \mathrm{~kg} / \mathrm{hr}$ \\
In-plant Load & $\left.9.03 \times 10^{6} \mathrm{lbs} / \mathrm{hr}\right)$ \\
Net Power Output & $65 \mathrm{MWe}$ \\
\hline
\end{tabular}

At the time the middle-of-run cycle is instituted, it will be necessary to add equipment. Because of the decreasing brine temperature, more brine will be required. The hydrocarbon/brine heat exchangers will require more surface. Another heat exchange unit will be added, increasing the surface by $50 \%$. The added exchanger will offset the higher pressure drop due to the increased brine circulation. Since the hydrocarbon circulation will also increase, an additional hydrocarbon pump will be added. The turbine may have to be modifield to handle the increased flow. In addition, one condenser will be added and the cooling tower enlarged by $43 \%$. These modifications will be sufficient for the remaining life of the project and no further equipment additions will be necessary.

The middle-of-run fluid can be used for the remainder of the project life, or until the reservoir temperature declines to $163 \mathrm{C}(325 \mathrm{~F})$. As the reservoir temperature declines the flow of brine through the plant heat exchangers will 
increase to $4.47 \times 10^{6} \mathrm{~kg} / \mathrm{hr}\left(9.86 \times 10^{6} \mathrm{lbs} / \mathrm{hr}\right)$. However, the rate of circulation of the working fluid remains constant.

TRADE-OFF STUDIES

Sufficient design work was performed in Part A of this project to show that the binary process was the optimum process for generation of power at the Heber reservoir. In Part B of this project detailed trade-off studies have been performed to define the effect of the following variables on the cost of power produced:

- Minimum temperature difference (pinch) in the brine/hydrocarbon exchangers

- Log mean temperature difference in the hydrocarbon condenser

- Cooling tower approach to the atmospheric wet bulb temperature

- Cooling water temperature rise

- Selection of motor or turbine drives for process pumps

\section{Method of Approach}

Each of the above variables was studied over the expected range of operating feasibility. The method of approach was to estimate capital and operating costs for the plant and for the field installation at each assumed condition.

These costs were then used as input data to the economic analysis program developed as part of the Energy Conversion Study. The selected variable which gave the lowest power cost was deemed to be the optimum.

To obtain estimates of plant costs, the following sections of the cost estimate presented in the Energy Conversion Study were selected for estimation: major equipment, concrete, piping and electrical. The other sections, site preparation, structural, instrumentation, insulation and painting are relatively insensitive to changes in process conditions and are assumed to be constant. 
Total plant costs were estimated by employing factors developed in the base cost estimate.

Field costs depend on brine requirements. Costs of production, injection and expected dry wells were estimated for each case. The costs of production and injection facilities (surface installation) were developed from the estimate summary sheet (Figure 8) shown in the Energy Conversion Study. Only pressure vessels, filters, and site preparation sections remained unchanged for all cases.

Operating and maintenance costs were derived from plant and field estimates as described in the Energy Conversion Study.

The results of these studies are presented in Tables 3-1 through 3-6. It is to be noted that the total estimated power costs in these tables are somewhat lower than the power costs calculated for the preliminary design presented in this report. The costs in the tables were developed employing thermodynamic cycles, in which the expansion of the working fluid passes through the two-phase region. While such cycles appear attractive it has not yet been established whether a turbine can be designed to operate efficiently in the two-phase region. Accordingly, we pursued a conservative approach for the preliminary design and selected cycles which 1ie outside the two-phase region. Because the cycles used in the trade-off studies are very similiar to the one selected for the preliminary design, we believe that the results of the trade-off studies are valid for the slightly different conditions used in the preliminary design.

\section{Effect of Brine/Hydrocarbon Exchanger Pinch Point on Power Cost}

The temperature pinch which occurs between the brine and the working fluid in the brine/hydrocarbon exchanger is a design variable which affects the size and cost of the exchanger. Pinch temperature differences of $5.5 \mathrm{C} \mathrm{(10} \mathrm{F),}$ $8.3 \mathrm{C}(15 \mathrm{~F})$, and $11.1 \mathrm{C}(20 \mathrm{~F})$ were investigated while holding constant the hydrocarbon circulation rate and turbine inlet and outlet conditions. As 
the pinch temperature difference is increased by raising the return temperature of the brine to the field, the cost of the brine-hydrocarbon exchangers decreases at the expense of higher brine rates. As shown in Table 3-1, with an increase from $5.5 \mathrm{C}$ pinch to $11.1 \mathrm{C}$ pinch, the cost of the exchangers drops from $\$ 1,570,000$ to $\$ 815,000$ reducing by 4.4 percent the capital cost of the plant. The brine requirements increase 10.5 percent, raising the total field cost from 6.5 percent, from $\$ 11,460,000$ to $\$ 12,210,000$. Power conversion costs reflect the lower plant costs, while energy (field related) costs go up. The additional energy costs offset the savings in plant related expenses, resulting in increased total power costs as the temperature pinch increases.

It appears that the smaller the pinch point the better. However, designing for too small a pinch point may unduly restrict brine flow and for this reason we selected a pinch point of $15 \mathrm{~F}$.

Effect of Condenser Log Mean Temperature Difference on Power Cost

In order to determine how the mean temperature difference in the condenser would affect the cost of power from the plant, the cooling water temperature profile was left constant, water coming in at $32.2 \mathrm{C}(90 \mathrm{~F})$ and leaving at about $43.3 \mathrm{C}(110 \mathrm{~F})$, and the turbine exhaust temperature changed to achieve the desired mean temperature difference. Table 3-2 shows that an increase in mean temperature difference from $6.1 \mathrm{C}(11 \mathrm{~F})$ to $17.2 \mathrm{C}(31 \mathrm{~F})$, requires an increase in turbine exhaust temperature from $76 \mathrm{C}(152 \mathrm{~F})$ to $73 \mathrm{C}(164 \mathrm{~F})$, resulting in a corresponding reduction in the power generated by each pound of working fluid circulated. Consequently, a 25 percent increase in cooling water circulation and about a 22 percent increase in hydrocarbon circulation and brine rate were required. These changes affected significantly the cost of some equipment but the net effect on plant cost was very sma11. The $\$ 1,087,000$ reduction in the cost of condensers compensated for the increase in the cost of the hydrocarbon and the cooling water circulation pumps, the cooling tower and the turbine-generator. The cost of energy conversion therefore changes slightly while the cost of energy increases. The net 
result is an 8.4 percent increase in power cost as the temperature difference increases from $6.1 \mathrm{C}$ to $17.2 \mathrm{C}$. Consequently, the condensers should be designed for a small $\log$ mean temperature difference to take advantage of favorable economics. For the power cycle recommended in this study, a $\log$ mean temperature difference of $7.1 \mathrm{C}(12.7 \mathrm{~F})$ was selected.

Effect of Cooling Tower Approach to Wet Bulb Temperature Cost

The cost of power was estimated for three cooling tower approaches, 5.5 C $(10 \mathrm{~F}), 4.4 \mathrm{C}(8 \mathrm{~F})$, and $2.8 \mathrm{C}(5 \mathrm{~F})$. A reduction in cooling tower approach causes an equal reduction in cooling water temperature. There are two possible ways of utilizing this advantage. One alternative is to increase the temperature difference in the hydrocarbon condensers; the other one, is to lower the hydrocarbon turbine outlet temperature. Both alternatives have been evaluated over the above range of approaches. The results are presented in Tables 3-3 and 3-4.

The increase of the temperature difference in the hydrocarbon condensers from $5.5 \mathrm{C}(10 \mathrm{~F})$ to $6.6 \mathrm{C}(1.2 \mathrm{~F})$ causes a reduction in the cost of the condensers, cooling water circulation pumps and cooling water piping. However, the closer approach to wet bulb causes a compensating increase in the cost of the cooling tower and its basin. The result, shown in Table 3-3 is a slight increase in plant cost, which coupled with an unchanged field cost, makes the reduction in approach economically unattractive.

The reduction in the turbine outlet temperature from $56.1 \mathrm{C}$ (133 F) to $54.4 \mathrm{C}$ (130 F) increases the power output from every pound of working fluid used, causing a 4 percent reduction in both hydrocarbon circulation and brine rate. The cooling water circulation drops by 5.4 percent. As shown in Table 4, these changes have relatively little effect on related equipment costs. At the same time, the closer approach to wet bulb causes the cooling tower cost to increase 65 percent, from $\$ 1,000,000$ to $\$ 1,650,000$. The net effect is a significant increase in plant cost and a slightly more than compensating decrease in field cost. We conclude that the small saving $(0.14 \mathrm{mills} / \mathrm{kwh})$ 
in power cost as the approach to wet bulb is reduced involves a measure of risk in that we are requiring superior performance of the cooling tower rather than normal performance. For this reason we selected a $5.5 \mathrm{C}$ (10 F) approach for preliminary design.

\section{Effect of Cooling Water Temperature Rise on Power Cost}

The effect on power cost of three cooling water temperature rises, $6.1 \mathrm{C}$ ( $11 \mathrm{~F}$ ), $11.7 \mathrm{C}(21 \mathrm{~F})$ and $18.3 \mathrm{C}(33 \mathrm{~F})$, was studied. To obtain power cycles under this constraint, the cooling water inlet temperature was kept constant at $32.2 \mathrm{C}(90 \mathrm{~F})$ and the turbine exhaust temperature increased from $66.7 \mathrm{C} \mathrm{(152} \mathrm{F)}$ to $70 \mathrm{C}(158 \mathrm{~F})$. Table 5 shows that as the temperature rise increases the capital cost of the plant declines from $\$ 28,310,000$ to $\$ 25,250,000$. This 10.8 percent drop is basically due to a 66 percent reduction in cooling water circulation, requiring smaller pumps and cooling tower. However, the brine rate, basically identical in the $6.1 \mathrm{C}$ and $11.7 \mathrm{C}$ temperature rise cases, increases 3 percent in the $18.3 \mathrm{C}$ temperature rise case. This increment is due to the higher turbine outlet conditions which make the power cycle less efficient. Consequently, even though the cost of energy conversion is the lowest, $16.77 \mathrm{mills} / \mathrm{kwh}$, the energy or field. related costs are the highest. The result is a minimum power cost occurring around the $11.7 \mathrm{C}$ temperature rise. After considering this and other process variables we selected a $10.1 \mathrm{C}(18.2 \mathrm{~F})$ cooling water temperature rise for the preliminary design case.

Hydrocarbon Circulation Pumps

A detailed study was made to optimize the design basis for the hydrocarbon circulation pumps. The primary purpose of the study was to determine the optimum combination of the following variables:

- Horizontal and/or vertical design

- Series and/or parallel flow

- Motor and/or turbine drive

- Number of pumps 
The factors involved in the determination of the optimum included cost, availability and operational flexibility. Five alternate pump systems combining the above variables were selected for the study. Piping schematics of the alternates are shown on Figure 3-2. A brief description of the alternates follows:

Alternate I, - Six vertical pumps in parallel; motor drive

Alternate II, - Three vertical pumps in parallel; motor drive

Alternate III, - Three vertical pumps in parallel; two turbine, one motor drive

Alternate IV, - The following two systems in parallel:

(a) one vertical motor driven pump in

series with one horizontal turbine

driven pump

(b) one vertical motor driven pump in series with two horizontal pumps in parallel, one turbine driven and the other motor driven

Alternate V, - Two systems in paralle1, each system consisting of a motor driven vertical pump in series with a motor driven horizontal pump.

The following factors had a bearing on the combination of variables in the above alternates:

- Horizontal pumps require vertical pumps in series to provide adequate NPSH

- If turbine drives are used, at least one motor driven unit or system is required for plant start up.

- The minimum number of systems in parallel required to handle the total hydrocarbon flow rate is established by equipment sizes presently available.

All pump systems were sized to handle a total hydrocarbon flow rate similar to that used in one of the trade-off studies conducted to optimize the process. The flow rate is approximately 3 percent higher than that for the case ultimately selected for the plant design. Total head requirements are identical. 
Turbine drivers were considered as operating in parallel with the plant turbine-generator set handling the hydrocarbon vapor at the same inlet and outlet conditions, thus reducing the required size of the turbine-generator set.

Cost comparisons considered not only the pumps and drivers but the changes in associated piping and insulation, instrumentation, civil and electrical requirements. For turbine drive units, the resultant decrease in required size of the plant turbine-generator set was taken into account.

Efficiencies assumed for the study were as follows: turbine-expander - 85 per cent, generator - 98 percent, pump turbine drivers - approximately 83 percent. A geared speed reducer would be required for the pump turbine driven units with a mechanical efficiency of 97 percent. Pump electric motor driver efficiencies for the required horsepowers ranged from 93 percent to 97 percent. The turbine requires a gear reduction unit which reduces efficiency of the turbine drive system. With high electric motor efficiencies the difference between turbine drive and motor drive would be minimal and was therefore not considered.

The cost summary of the five alternates is shown in Table I. Following is a tabulation of the results in the order of ascending cost.

\begin{tabular}{|c|c|}
\hline Alternate Case & Cost \\
\hline V & $4,665,000$ \\
\hline IV & $4,749,000$ \\
\hline I & $4,777,000$ \\
\hline III & $4,885,000$ \\
\hline II & $5,024,000$ \\
\hline
\end{tabular}

Cases II, III, IV and V utilize pumps at the upper end of capacity/head limits with a limited number of manufacturers available. Flexibility is also limited 
due to fewer number of systems in parallel. In cases where two pumps are connected in series, a failure of either pump would remove the other from operation.

Alternate I provides the best combination of cost, flexibility and manufacturer availability. Consequently, six motor driven vertical pumps in parallel were selected for start-of-run process conditions.

The use of turbine drives for the cooling water pumps was not considered because these pumps require only a fraction of the horsepower required for the hydrocarbon pumps. If turbine drives proved impractical for the hydrocarbon pumps they should not be considered for cooling water service.

\section{ECONOMIC ANALYSIS}

In the previously submitted Energy Conversion Study we prepared a capital cost estimate of the Heber binary plant, together with estimates of fuel cost and the cost of electrical power delivered to a load center. This section contains an updated capital cost of the power plant, together with an estimate of the cost of future additions to the plant to provide for the anticipated temperature decline. We have also developed new estimates of the cost of power from the plant at the start.

\section{Capital Cost}

The updated initial capital cost is presented in Figure 3-3. The estimated cost is $\$ 29,634,000$ as compared with the earlier estimate of $\$ 28,500,000$. This estimate is prepared on the same basis as the earlier one. It reflects changes in design and in some cases improved accuracy. The major differences between the two estimates are as follows:

Major equipment increased by about $\$ 300,000$. Heat exchangers went up, the cooling tower went down and freight was listed as a major equipment account rather than an indirect field cost. 
- Construction items increased by about $\$ 750,000$. This reflects a reduction in the cost of pipe, valves and fittings and an increase in the cost of concrete, both changes resulting from a more accurate material take-off than before.

- Fee, contingency and escalation were increased in proportion to total plant cost.

This estimate, like the earlier one, is for a battery limits plant. Excluded from the cost are the following:

- Cost of field collection and reinjection facilities

- Cost of electrical transmission facilities to a loadcenter

- Cost of land

- Costs incurred by the Owner for managing the project and for obtaining the necessary permits to construct.

- Cost of royalties, if any

- Interest and taxes during construction

As before, the estimate assumes that the project will be completed by late 1979 and escalation is estimated on this basis.

An additive expenditure of about $\$ 3,800,000$ will be required to modify the plant for low temperature operation. This expenditure assumes that the addition would be made at the same time the original plant is constructed. In reality, the expenditure would be made at a later date, i.e., about eight years after initial operation.

\section{Cost of Power}

The performance of the plant has been improved slightly over the base case that was reported in the Energy Conversion Study. As a result, the geothermal fluid requirement of the plant is reduced, and consequently, the fuel cost at the plant is reduced. Because of the increase in capita1, the 
conversion cost increases over the base case. A comparison of the base case and the preliminary design case is as follows:

$\begin{array}{lcc} & \frac{\text { This Case }}{\text { Mills } / \mathrm{kwh}} & \frac{\text { Base Case }}{\text { Mills } / \mathrm{kwh}} \\ \text { Cost of Energy } & \frac{16.53}{16.60} & \frac{18.25}{\text { Cost of Power Conversion }} \\ \text { Cost of Transmission } & 19.03 & 0.28 \\ \text { Total Cost } & \frac{0.28}{35.84} & 35.22\end{array}$

A rigorous analysis of the effect of temperature decline of the reservoir on the cost of power is beyond the scope of this study. Suffice it to say that the cost clearly will increase because of the continued effects of inflation, the additional capital investment in the plant and the additional costs associated with producing and reinjection of more brine. 
A - 50/50 ISOBUTANE-ISOPENTANE

B - 35/55 PROPANE-ISOBUTANE

C - 20/60/20 PROPANE-ISOBUTANE-ISOPENTANE

D - 80/20 ISOBUTANE-ISOPENTANE

E - 80/20 ISOBUTANE-ISOPENTANE

F - 10/90 PROPANE-ISOBUTANE

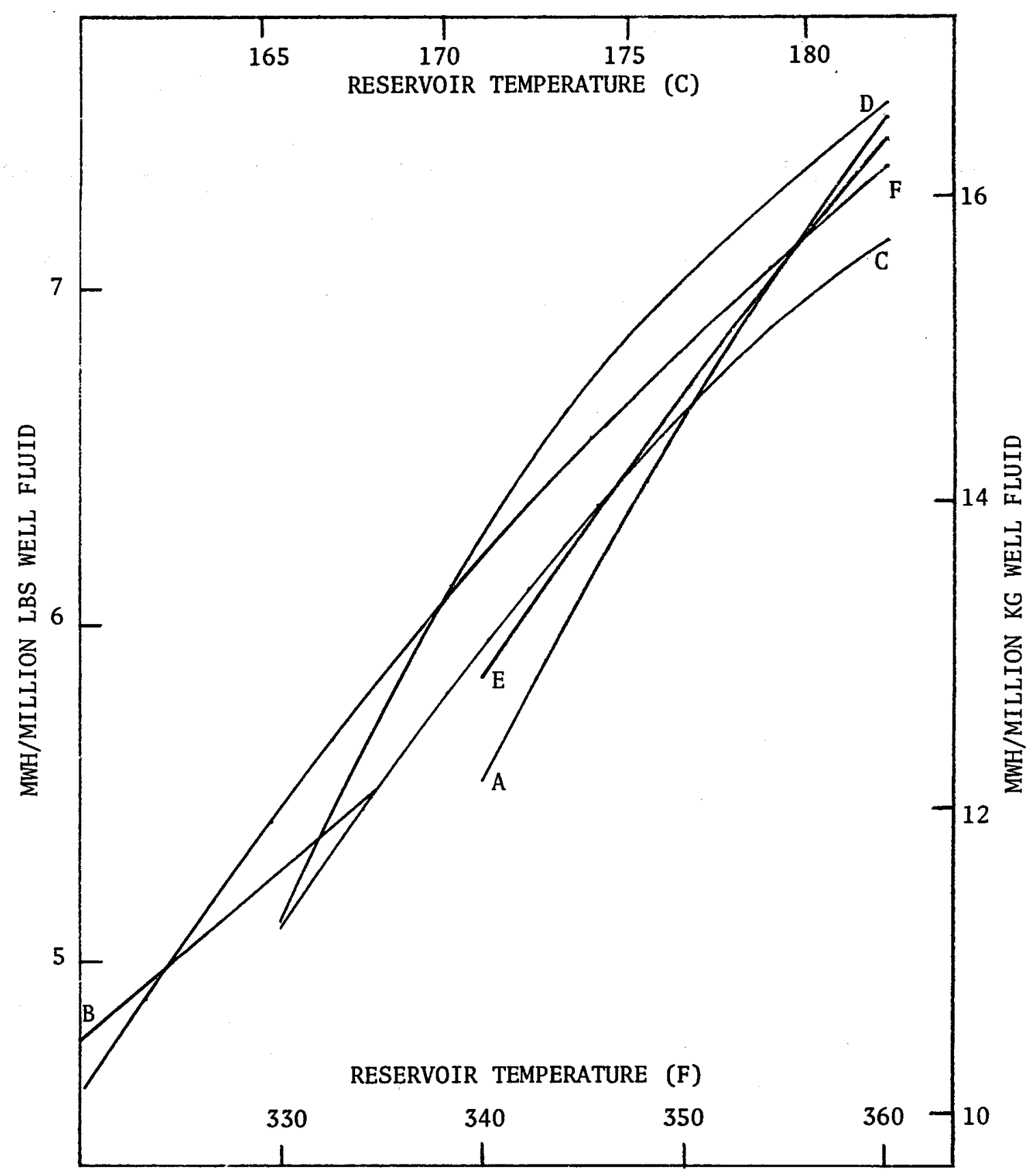

Figure 3-1. Performance of Various Geothermal Binary Cycles 


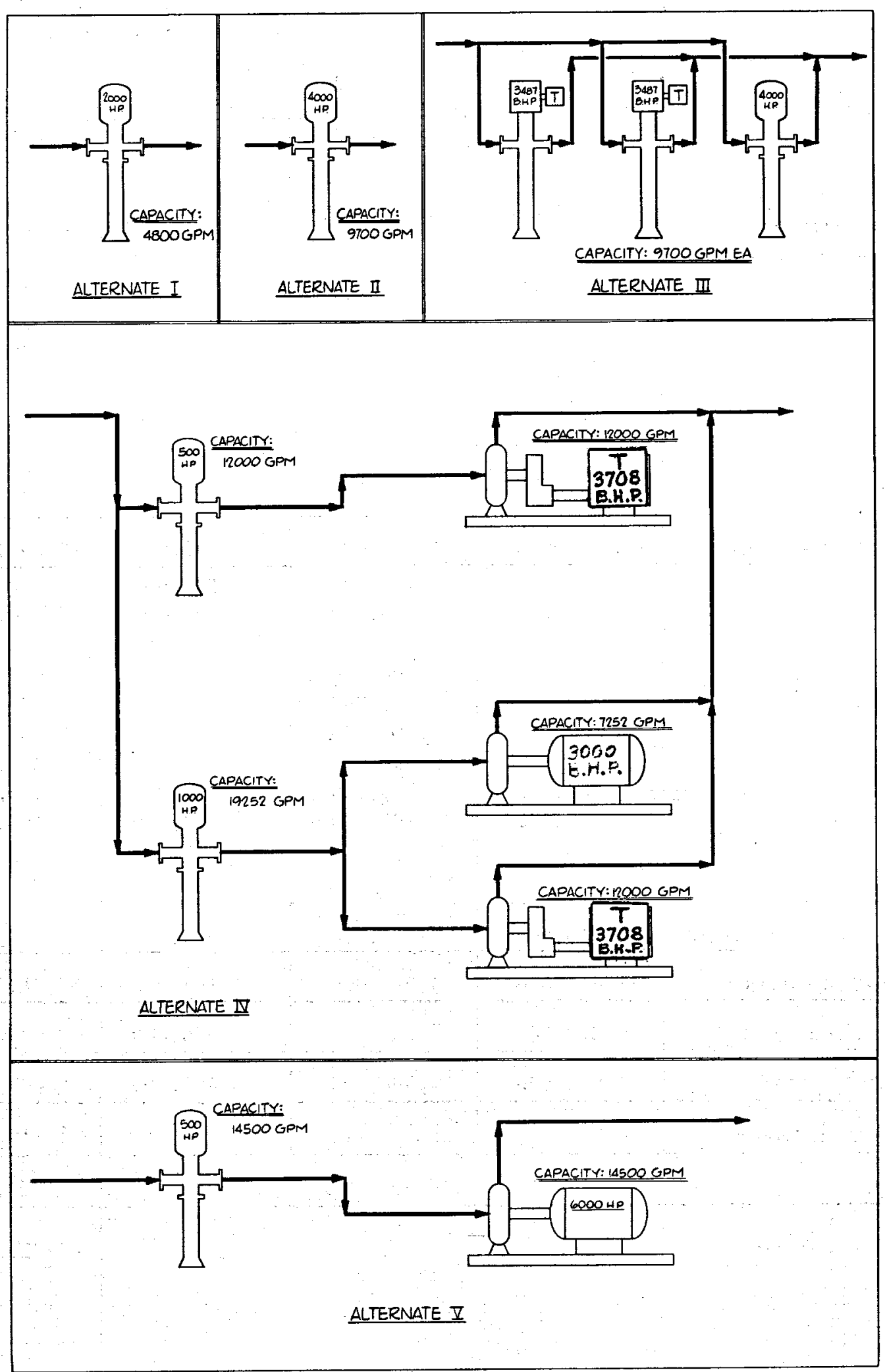

Figure 3-2. Alternative Pump Configurations 


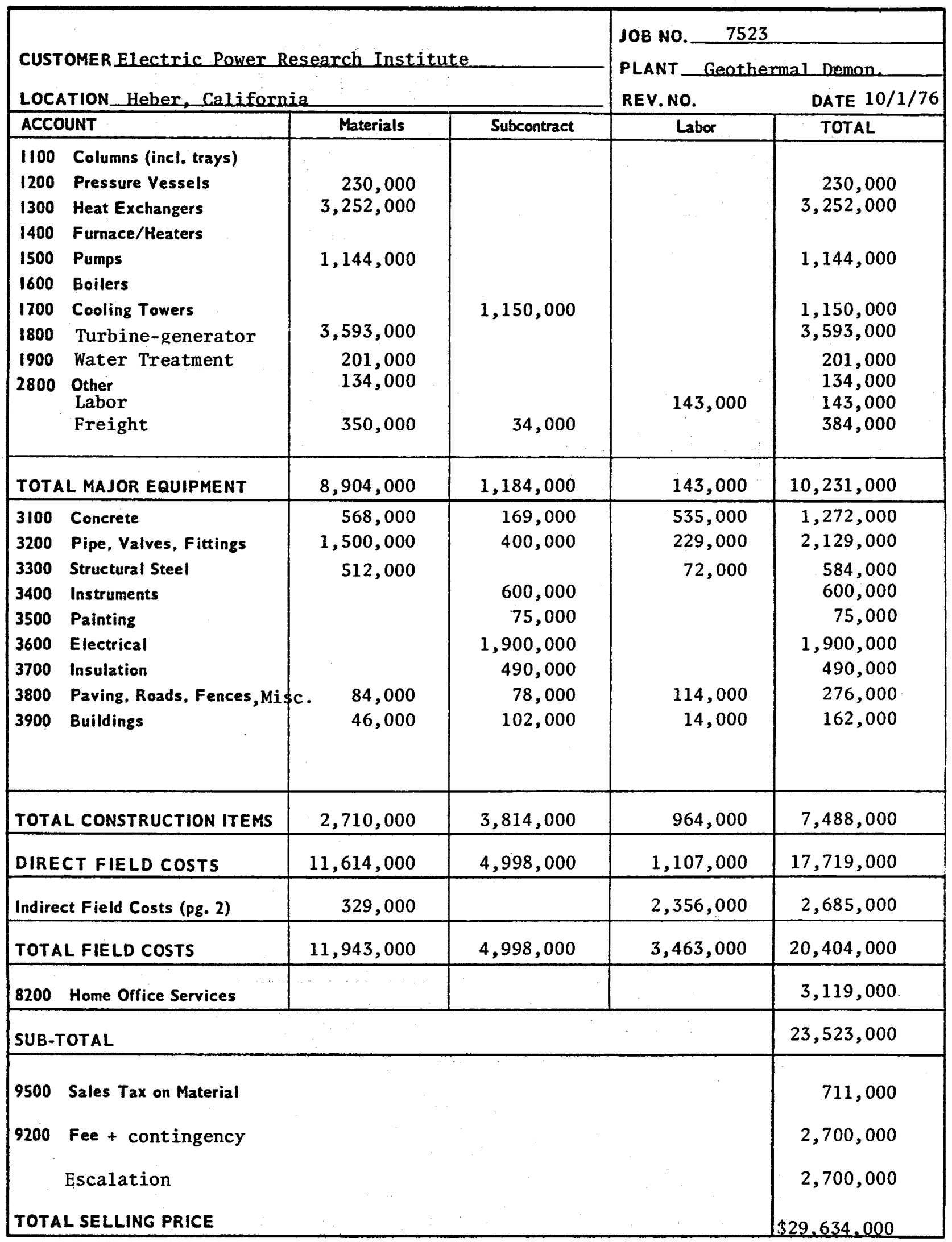

Figure 3-3. Estimate Summary Sheet 
Table 3-1

EFFECT OF BRINE/HYDROCARBON EXCHANGER PINCH POINT ON POWER COST

\begin{tabular}{|c|c|c|c|}
\hline PINCH POINT & $5.5 \mathrm{C}(10 \mathrm{~F})$ & $8.3 \mathrm{C}(15 \mathrm{~F})$ & $11.1 \mathrm{C}(20 \mathrm{~F})$ \\
\hline \multicolumn{4}{|l|}{ PLANT OPERATING CONDITIONS } \\
\hline BRINE RATE, $10^{3} \mathrm{~kg} / \mathrm{hr}\left(10^{3} \mathrm{lbs} / \mathrm{hr}\right)$ & $2,936(6,473)$ & $3,076(6,781)$ & $3,245(7,155)$ \\
\hline HYDROCARBON* CIRCULATION RATE, $10^{3} \mathrm{~kg} / \mathrm{hr}\left(10^{3} \mathrm{lbs} / \mathrm{hr}\right)$ & $3,639(8,023)$ & $3,639 \cdot(8,023)$ & $3,639(8,023)$ \\
\hline TURBINE INLET - PRESSURE, kPa (psia) & $3,447 \quad(500)$ & $3,447 \quad(500)$ & $3,447 \quad(500)$ \\
\hline - TEMPERATURE, C (F) & $(300)$ & $(300)$ & $(300)$ \\
\hline TURBINE OUTLET - PRESSURE, kPa (psia) & $458 \quad(66.4)$ & $458 \quad(66.4)$ & $458 \quad(66.4)$ \\
\hline - TEMPERATURE, C (F) & $68 \quad(154)$ & $68 \quad(154)$ & $68 \quad(154)$ \\
\hline $\begin{aligned} \text { COOLING WATER } & - \text { TEMPERATURE, C (F) } \\
& - \text { CIRCULATION RATE, } 10^{3} \mathrm{~m}^{3} / \mathrm{hr}\left(10^{3} \mathrm{gpm}\right)\end{aligned}$ & $\begin{array}{rr}3.2 & (90) \\
26.96 & (118.7)\end{array}$ & $\begin{array}{rr}32 & (90) \\
26.96 & (118.7)\end{array}$ & $\begin{array}{rr}32 & (90) \\
26.96 & (118.7)\end{array}$ \\
\hline \multirow{2}{*}{\multicolumn{4}{|c|}{$\begin{array}{l}\text { PLANT CAPITAL COST, } K \$ \\
\text { MAJOR EQUIPMENT (MATERIAL) }\end{array}$}} \\
\hline & & & \\
\hline HYDROCARBON ACCUMULATORS & 190 & 173 & 164 \\
\hline BRINE/HYDROCARBON EXCHANGERS & 1,570 & 1,080 & 815 \\
\hline HYDROCARBON CONDENSERS & 1,310 & 1,310 & 1,310 \\
\hline HYDROCARBON CIRCULATION PUMPS & 613 & 613 & 613 \\
\hline COOLING WATER CIRCULATION PUMPS & 253 & 253 & 253 \\
\hline COOLING TOWER & 1,050 & 1,050 & 1,050 \\
\hline TURBINE-GENERATOR & 3,590 & 3,590 & 3,590 \\
\hline CONCRETE (LABOR AND MATERIAL) & 362 & 362 & 362 \\
\hline PIPING (LABOR, MATERIAL AND SUBCONTRACT) & 2,419 & 2,419 & 2,419 \\
\hline ELECTRICAL (MATERIAL AND SUBCONTRACT) & 1,775 & 1,775 & 1,775 \\
\hline TOTAL & 26,720 & 25,950 & 25,540 \\
\hline \multicolumn{4}{|l|}{ FIELD CAPITAL COST, $\mathrm{K} \$$} \\
\hline TOTAL & 11,460 & 11,800 & 12,210 \\
\hline \multicolumn{4}{|l|}{ POWER COST, mills/kwh } \\
\hline CONVERSION AND TRANSMISSION & 17.60 & 17.16 & 16.92 \\
\hline ENERGY & 15.22 & 15.90 & 16.57 \\
\hline TOTAL & 32.82 & 33.06 & 33.49 \\
\hline
\end{tabular}

*HYDROCARBON MIXTURE CONSISTS OF 65 MOLE \% ISOBUTANE AND 35 MOLE \% ISOPENTANE 
Table 3-2

EFFECT OF CONDENSER LOG MEAN TEMPERATURE DIFFERENCE ON POWER COST

\begin{tabular}{|c|c|c|c|}
\hline LOG MEAN TEMPERATURE DIFFERENCE & $6.1 \mathrm{C}(11 \mathrm{~F})$ & $11.7 \mathrm{C}(21 \mathrm{~F})$ & $17.2 \mathrm{C}(31 \mathrm{~F})$ \\
\hline \multicolumn{4}{|l|}{$\begin{array}{l}\text { PLANT OPERATING CONDITIONS } \\
\text { BRINE RATE, } 10^{3} \mathrm{~kg} / \mathrm{hr}\left(10^{3} \mathrm{lbs} / \mathrm{hr}\right)\end{array}$} \\
\hline $\begin{array}{l}\text { BRINE RATE, } 10^{3} \mathrm{~kg} / \mathrm{hr}\left(10^{3} \mathrm{lbs} / \mathrm{hr}\right) \\
\text { HYDROCARBON* CIRCULATION RATE, } 10^{3} \mathrm{~kg} / \mathrm{hr}\left(10^{3} \mathrm{lbs} / \mathrm{hr}\right)\end{array}$ & $\begin{array}{l}2,924(6,447) \\
3,491(7,696)\end{array}$ & $\begin{array}{l}3,233(7,127) \\
3,842(8,470)\end{array}$ & $\begin{array}{l}3,580(7,892) \\
4,253(9,376)\end{array}$ \\
\hline TURBINE INLET - PRESSURE, $\mathrm{kPa}$ (psia) & $3,447 \quad(500)$ & $3,447 \quad(500)$ & $3,447 \quad(500)$ \\
\hline - TEMPERATURE, C (F) & $(300)$ & $(300)$ & $(300)$ \\
\hline TURBINE OUTLET - PRESSURE, kPa (psia) & $(62)$ & (72) & (82) \\
\hline - TEMPERATURE, C (F) & $(152)$ & (158) & (164) \\
\hline $\begin{aligned} \text { COOLING WATER } & - \text { TEMPERATURE, C (F) } \\
& - \text { CIRCULATION RATE, } 10^{3} \mathrm{~m}^{3} / \mathrm{hr}\left(10^{3} \mathrm{gpm}\right)\end{aligned}$ & $\begin{array}{rr}32 & (90) \\
25.68 & (113.1)\end{array}$ & $\begin{array}{rr}32 & (90) \\
28.76 & (126.7)\end{array}$ & $\begin{array}{rr}32 & (90) \\
32.24 & (142.0)\end{array}$ \\
\hline \multicolumn{4}{|l|}{$\begin{array}{l}\text { PLANT CAPITAL COST, } \mathrm{K} \$ \\
\text { MAJOR EQUIPMENT (MATERIAL) }\end{array}$} \\
\hline HYDROCARBON ACCUMULATORS & 175 & 177 & 188 \\
\hline BRINE/HYDROCARBON EXCHANGERS & 1,160 & 1,200 & 1,290 \\
\hline HYDROCARBON CONDENSERS & 1,810 & 994 & 723 \\
\hline HYDROCARBON CIRCULATION PUMPS & 550 & 643 & 660 \\
\hline COOLING WATER CIRCULATION PUMPS & 253 & 280 & 280 \\
\hline COOLING TOWER & 1,050 & 1,150 & 1,300 \\
\hline TURBINE-GENERATOR & 3,580 & 3,610 & 3,640 \\
\hline CONCRETE (LABOR AND MATERIAL) & 361 & 374 & 392 \\
\hline PIPING (LABOR, MATERIAL AND SUBCONTRACT) & 2,399 & 2,450 & 2,472 \\
\hline ELECTRICAL (MATERIAL AND SUBCONTRACT) & 1,725 & 1,775 & 1,795 \\
\hline TOTAL & 26,590 & 26,040 & 26,210 \\
\hline \multicolumn{4}{|l|}{ FIELD CAPITAL COST, $K \$$} \\
\hline TOTAL & 11,460 & 12,210 & 12,950 \\
\hline \multicolumn{4}{|l|}{ POWER COST, mills/kwh } \\
\hline CONVERSION AND TRANSMISSION & 17.49 & 17.24 & 17.41 \\
\hline ENERGY & 15.20 & 16.55 & 18.03 \\
\hline TOTAL & 32.69 & 33.79 & 35.44 \\
\hline
\end{tabular}

*HYDROCARBON MIXTURE CONSISTS OF 65 MOLE $\%$ ISOBUTANE AND 35 MOLE $\%$ ISOPENTANE 
Table 3-3

EFFECT OF COOLING TOWER APPROACH TO WET BULB TEMPERATURE ON POWER COST

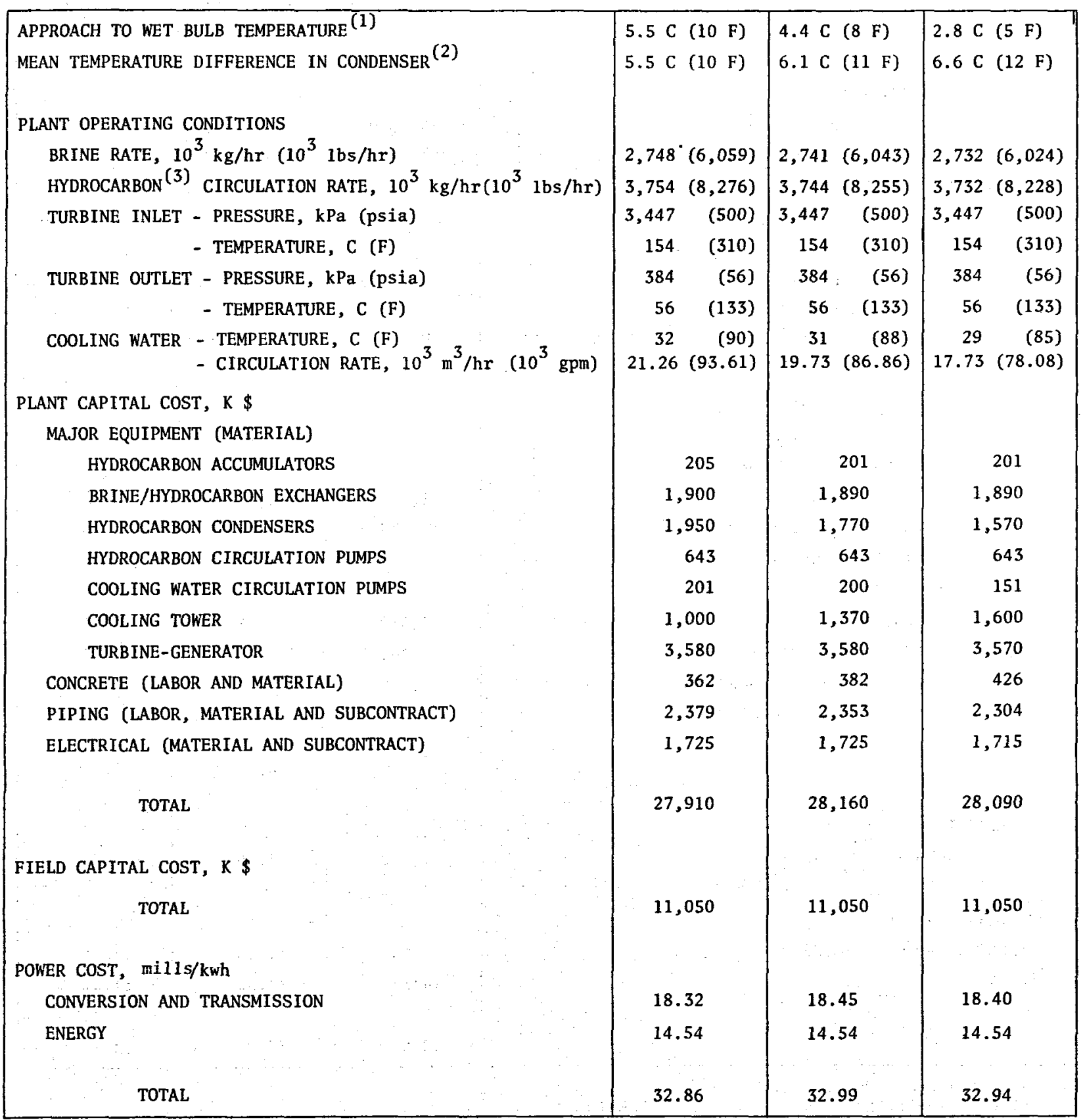

1) WET BULB TEMPERATURE: $26.7 \mathrm{C}$ ( $80 \mathrm{~F})$

2) SECONDARY VARIABLE: MEAN TEMPERATURE DIFFERENCE IN CONDENSER

3) HYDROCARBON MIXTURE CONSISTS OF 50 MOLE \% ISOBUTANE AND 50 MOLE \% ISOPENTANE 
Table 3-4

EFFECT OF COOLING TOWER APPROACH TO WET BULB TEMPERATURE ON POWER COST

\begin{tabular}{|c|c|c|c|}
\hline $\begin{array}{l}\text { APPROACH TO WET BULB TEMPERATURE } \\
\text { TURBINE OUTLET TEMPERATURE }\end{array}$ & $\begin{array}{l}5.5 \mathrm{C}(10 \mathrm{~F}) \\
56.1 \mathrm{C}(133 \mathrm{~F})\end{array}$ & $\begin{array}{l}4.4 \mathrm{C}(8 \mathrm{~F}) \\
55.5 \mathrm{C}(132 \mathrm{~F})\end{array}$ & $\begin{array}{l}2.8 \mathrm{C}(5 \mathrm{~F}) \\
54.4 \mathrm{C}(130 \mathrm{~F})\end{array}$ \\
\hline \multicolumn{4}{|l|}{ PLANT OPERATING CONDITIONS } \\
\hline $\begin{array}{l}\text { BRINE RATE, } 10^{3} \mathrm{~kg} / \mathrm{hr}\left(10^{3} \mathrm{lbs} / \mathrm{hr}\right) \\
\text { HYDROCARBON }\end{array}$ & $\begin{array}{ll}2,748 & (6,059) \\
3,754 & (8,276)\end{array}$ & $\begin{array}{ll}2,719 & (5,994) \\
3,689 & (8,133)\end{array}$ & $\begin{array}{ll}2,639 & (5,817) \\
3,594 & (7,924)\end{array}$ \\
\hline TURBINE INLET - PRESSURE, $\mathrm{kPa}$ (psia) & $3,447 \quad(500)$ & $3,447 \quad(500)$ & $3,447 \quad(500)$ \\
\hline - TEMPERATURE, C (F) & $(310)$ & $(310)$ & $(310)$ \\
\hline TURBINE OUTLET - PRESSURE, kPa (psia) & $(56)$ & (54) & $(52)$ \\
\hline - TEMPERATURE, C (F) & $56.1 \quad(133)$ & $55.5 \quad(132)$ & $(130)$ \\
\hline $\begin{aligned} \text { COOLING WATER } & - \text { TEMPERATURE, } C(F) \\
& - \text { CIRCULATION RATE, } 10^{3} \mathrm{~m}^{3} / \mathrm{hr}\left(10^{3} \mathrm{gpm}\right)\end{aligned}$ & $\begin{array}{rr}32 & (90) \\
21.26 & (93.61)\end{array}$ & $\begin{array}{rr}31 & (88) \\
20.80 & (91.60)\end{array}$ & $\begin{array}{rr}29 & (85) \\
20.12 & (88.60)\end{array}$ \\
\hline $\begin{array}{l}\text { PLANT CAPITAL COST, } K \$ \\
\text { MAJOR EQUIPMENT (MATERIAL) }\end{array}$ & \multicolumn{2}{|c|}{ MAJOR EQUIPMENT (MATERIAL) } & \\
\hline HYDROCARBON ACCUMULATORS & 205 & 201 & 197 \\
\hline BRINE/HYDROCARBON EXCHANGERS & 1,900 & 1,850 & 1,750 \\
\hline HYDROCARBON CONDENSERS & 1,950 & 1,920 & 1,880 \\
\hline HYDROCARBON CIRCULATION PUMPS & 643 & 643 & 608 \\
\hline COOLING WATER CIRCULATION PUMPS & 201 & 201 & 200 \\
\hline COOLING TOWER & 1,000 & 1,200 & 1,650 \\
\hline TURBINE-GENERATOR & 3,580 & 3,580 & 3,570 \\
\hline CONCRETE (LABOR AND MATERIAL) & 362 & 386 & 443 \\
\hline PIPING (LABOR, MATERIAL AND SUBCONTRACT) & 2,379 & 2,373 & 2,373 \\
\hline ELECTRICAL (MATERIAL AND SUBCONTRACT) & 1,725 & 1,725 & 1,715 \\
\hline TOTAL & 27,910 & 28,130 & 28,660 \\
\hline \multicolumn{4}{|l|}{ FIELD CAPITAL COST, $\mathrm{K} \$$} \\
\hline TOTAL & 11,050 & 11,050 & 10,640 \\
\hline \multicolumn{4}{|l|}{ POWER COST, mil1s/kwh } \\
\hline CONVERSION AND TRANSMISSION & 18.32 & 18.43 & 18.71 \\
\hline ENERGY & 14.54 & 14.52 & 14.01 \\
\hline TOTAL & 32.86 & $\Rightarrow 32.95$ & 32.72 \\
\hline
\end{tabular}

1) WET BULB TEMPERATURE: $26.7 \mathrm{C}(80 \mathrm{~F})$

2) SECONDARY VARIABLE: TURBINE OUTLET TEMPERATURE

3) HYDROLARBON MIXTURE CONSISTS OF 50 MOLE : ISOBUTANE AND 50 MOLE \% ISOPENTANE 
Table 3-5

EFFECT OF COOLING WATER TEMPERATURE RISE ON POWER COST

\begin{tabular}{|c|c|c|c|}
\hline COOLING WATER TEMPERATURE RISE & $6.1 \mathrm{C}(11 \mathrm{~F})$ & $11.7 \mathrm{C}(21 \mathrm{~F})$ & $18.3 \mathrm{C}(33 \mathrm{~F})$ \\
\hline \multicolumn{4}{|l|}{ PLANT OPERATING CONDITIONS } \\
\hline BRINE RATE, $10^{3} \mathrm{~kg} / \mathrm{hr}\left(10^{3} \mathrm{lbs} / \mathrm{hr}\right)$ & $3,082(6,795)$ & $3,076(6,781)$ & $3,175(7,000)$ \\
\hline HYDROCARBON* CIRCULATION RATE, $10^{3} \mathrm{~kg} / \mathrm{hr}\left(10^{3} \mathrm{lbs} / \mathrm{hr}\right)$ & $3,665(8,080)$ & $3,639(8,023)$ & $3,784(8,343)$ \\
\hline TURBINE INLET - PRESSURE, $\mathbf{k P a}$ (psia) & $3,447 \quad(500)$ & $3,447 \quad(500)$ & $3,447 \quad(500)$ \\
\hline - TEMPERATURE, C (F) & $149 \quad(300)$ & $149(300)$ & $149 \quad(300)$ \\
\hline TURBINE OUTLET - PRESSURE, kPa (psia) & $432 \quad(63)$ & $458 \quad(66)$ & $501 \quad(73)$ \\
\hline - TEMPERATURE, C (F) & $67 \quad(152)$ & $68 \quad(154)$ & $70 \quad(158)$ \\
\hline COOLING WATER - TEMPERATURE, C (F) & $32 \quad(90)$ & $32(90)$ & $32(90)$ \\
\hline - CIRCULATION RATE, $10^{3} \mathrm{~m}^{3} / \mathrm{hr}\left(10^{3} \mathrm{gpm}\right)$ & $52.01(229.0)$ & $26.96(118.7)$ & $17.54(77.22)$ \\
\hline \multicolumn{4}{|l|}{ MAJOR EQUIPMENT (MATERIAL) } \\
\hline HYDROCARBON ACCUMULATORS & 175 & 173 & 179 \\
\hline BRINE/HYDROCARBON EXCHANGERS & 1,120 & 1,080 & 1,140 \\
\hline HYDROCARBON CONDENSERS & 1,300 & 1,310 & 1,470 \\
\hline HYDROCARBON CIRCULATION PUMPS & 643 & 613 & 643 \\
\hline COOLING WATER CIRCULATION PUMPS & 506 & 253 & 151 \\
\hline COOLING TOWER & 1,450 & 1,050 & 800 \\
\hline TURBINE-GENERATOR & 3,610 & 3,590 & 3,570 \\
\hline CONCRETE (LABOR AND MATERIAL) & 409 & 362 & 335 \\
\hline PIPING (LABOR, MATERIAL AND SUBCONTRACT) & 2,777 & 2,419 & 2,271 \\
\hline ELECTRICAL (MATERIAL AND SUBCONTRACT) & 1,855 & 1,775 & 1,715 \\
\hline TOTAL & 28,310 & 25,950 & 25,250 \\
\hline \multicolumn{4}{|l|}{ FIELD CAPITAL COST, $\mathrm{K} \$$} \\
\hline TOTAL & 11,800 & 11,800 & 12,210 \\
\hline \multicolumn{4}{|l|}{ POWER COST, mills/kwh } \\
\hline CONVERSION AND TRANSMISSION & 18.49 & 17.16 & 16.77 \\
\hline ENERGY & 15.90 & 15.90 & 16.46 \\
\hline TOTAL & 34.39 & 33.06 & 33.23 \\
\hline
\end{tabular}

*HYDROCARBON MIXTURE CONSISTS OF 65 MOLE \% ISOBUTANE AND 35 MOLE \% ISOPENTANE 
Table 3-6

HYDROCARBON CIRCULATION PUMP STUDY

\begin{tabular}{|c|c|c|c|c|c|}
\hline & ALTERNATE I & ALTERNATE II & ALTERNATE III & ALTERNATE IV & ALTERNATE $V$ \\
\hline HYDROCARBON CIRCULATION PUMPS & $\$ 683,000$ & $\$ 1,001,000$ & $\$ 1,247,000$ & $\$ 984,000$ & $\$ 582,000$ \\
\hline TURB INE-EXPANDER \& GENERATOR & $3,590,000$ & $3,590,000$ & $3,418,000$ & $3,374,000$ & $3,590,000$ \\
\hline PIPING & 122,000 & 97,000 & 62,000 & 189,000 & 106,000 \\
\hline INSTRUMENTATION & 4,000 & 2,000 & 19,000 & 21,000 & 2,000 \\
\hline CIVIL & 53,000 & 39,000 & 39,000 & 55,000 & 48,000 \\
\hline ELECTRICAL & 372,000 & 331,000 & 135,000 & 176,000 & 380,000 \\
\hline TOTAL $\quad[1]$ & $\$ 4,824,000$ & $\$ 5,060,000$ & $\$ 4,920,000$ & $\$ 4,799,000$ & $\$ 4,708,000$ \\
\hline
\end{tabular}

NOTES:

ALTERNATE I - six vertical pumps in parallel, motor drive

ALTERNATE II - three vertical pumps in parallel, motor drive

ALTERNATE III - three vertical pumps in parallel, one motor drive and two turbine drive

ALTERNATE IV. - (a) motor driven vertical pump in series with motor driven horizontal pump and turbine driven horizontal pump in parallel

(b) motor driven vertical pump in series with turbine driven horizontal pump

ALTERNATE V - motor driven vertical pump in series with motor driven horizontal pump, two systems in parallel 
C

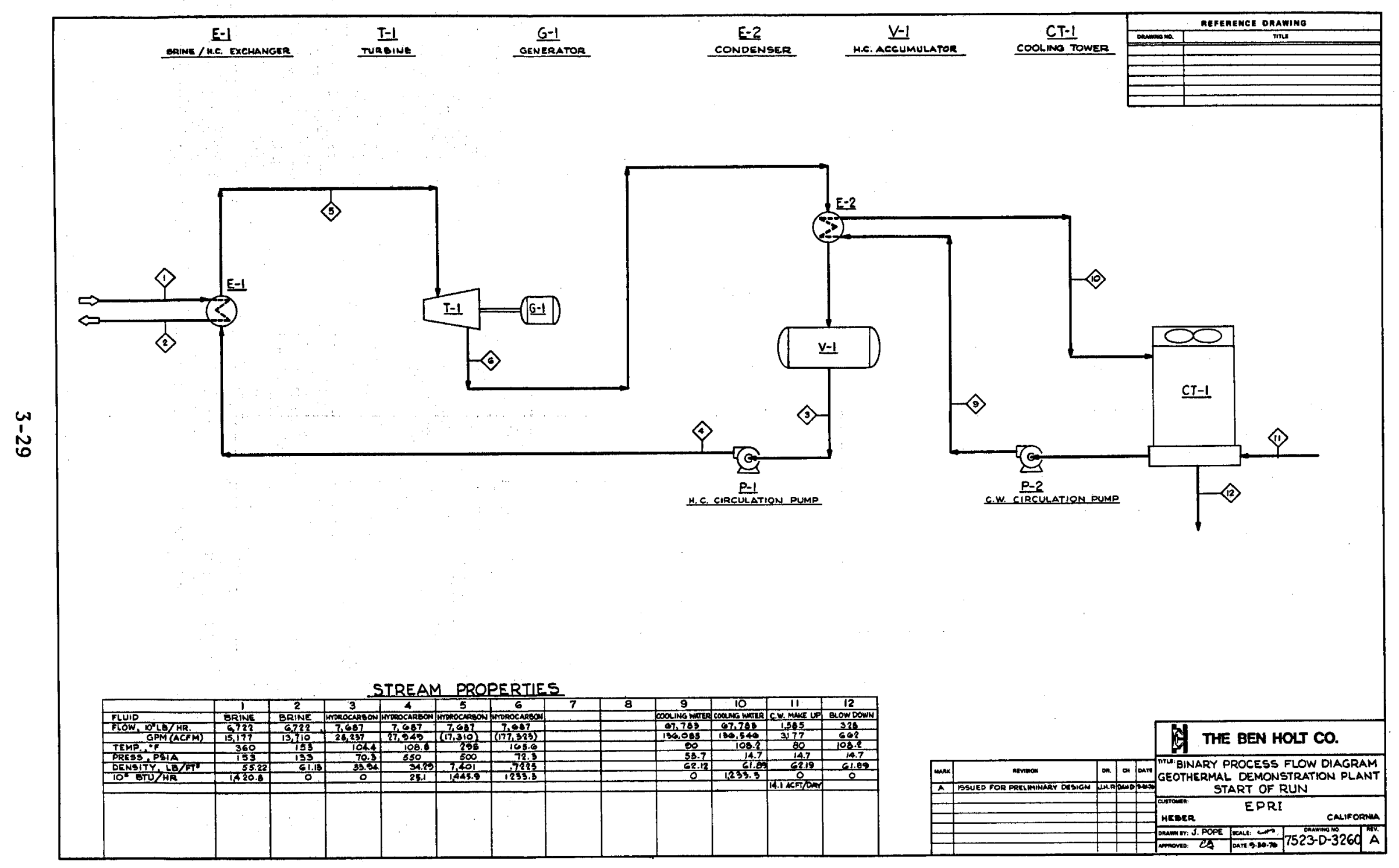




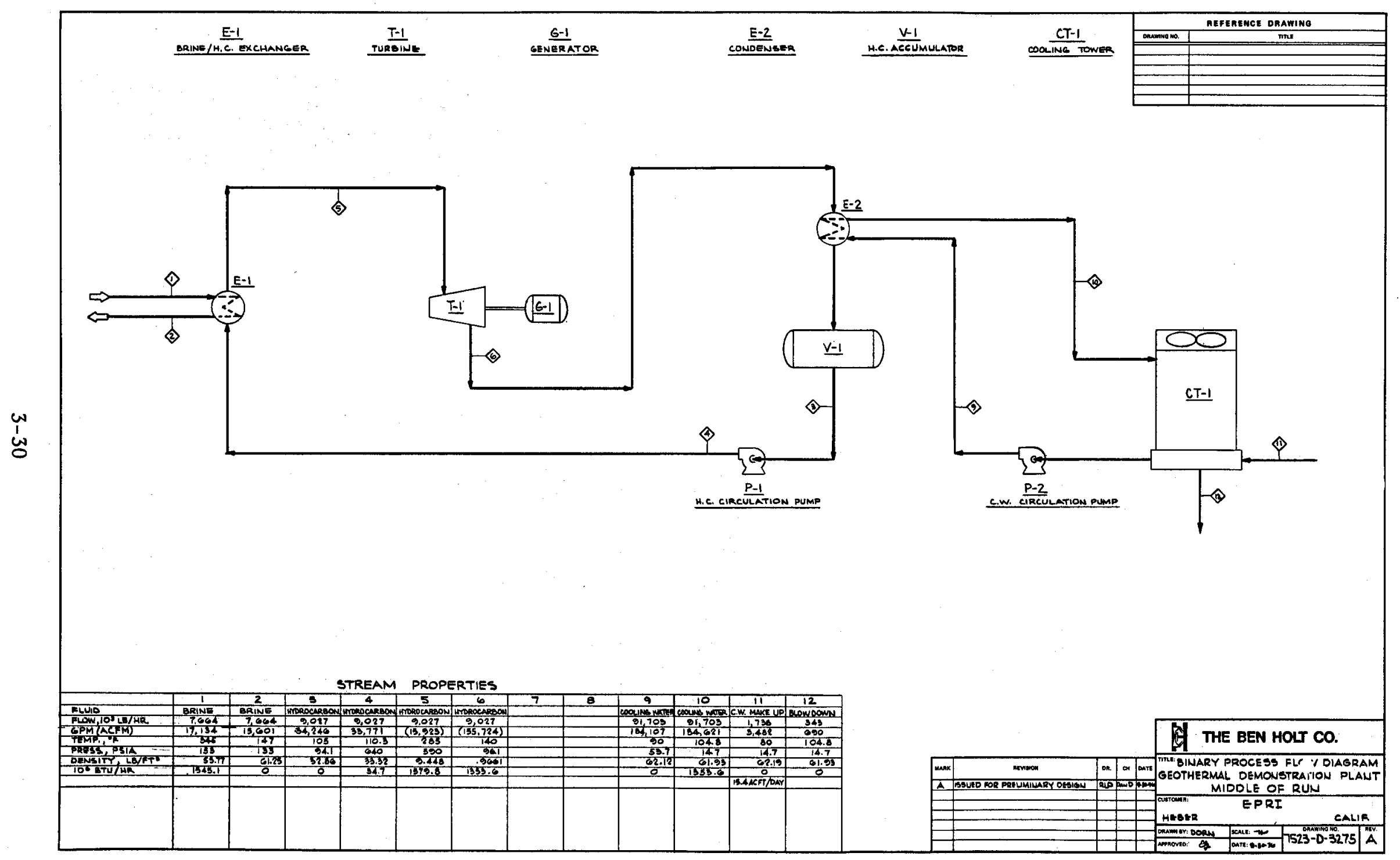

C 
Section 4

DESCRIPTION OF FACILITIES

The following features of the geothermal conversion plant are described in this section:

\author{
Plant layout \\ Energy conversion system \\ Cooling water system \\ Plant and instrument air system \\ Flare system \\ Fire water system \\ Electrical system \\ Piping \\ Instrumentation and control \\ Building and structures
}

The following preliminary design drawings are included as a part of the report.

Plot plan

Piping and instrumentation diagrams for the following systems:

Energy conversion

Cooling water

Plant and instrument air

F1are

Electrical single line drawings

Preliminary piping layout drawings 
PLANT LAYOUT

The plot plan for Heber is shown in Drawing No. 7523-E-3242. The "North" direction shown on this drawing is a plant-north. The actual orientation of the plant will not be determined until a specific plant site is selected. The plant contains four major, clearly defined functional areas as follows:

- Brine/hydrocarbon heat exchanger area located in the southeast corner of the site,

- Turbine-generator and electrical gear located at the southern edge of the site near the office and control building,

- Hydrocarbon condenser, accumulator, and circulating pump area located in the central portion of the plant site,

- Cooling water system area located at the northern edge of the site.

The plant has been arranged to allow for maximum flexibility as plant modifications are required to accommodate a reduction in geothermal fluid temperature over the plant lifetime. Area has been set aside for installation of additional brine/hydrocarbon heat exchangers, hydrocarbon condensers and accumulators, hydrocarbon feed pumps, cooling tower cells and circulating water pumps. Pipe sizes have been selected to permit required increases in flow during the plant lifetime.

Where possible a symmetrical layout has been observed consistent with the functional requirements of the equipment. Area has been set aside to permit removal of heat exchanger tubes, inspection and cleaning, and accessibility for maintenance equipment.

There are three buildings within the plant limits. The office and control room building located at the south edge of the site, the compressed air unit and maintenance shop building located in the southeastern section of the plant, and the water treatment system building on the northeastern section of the plant.

The site perimeter will be fenced with a 1.8 meter ( 6 foot) Cyclone-type fence with a 0.3 meter ( 1 foot) "invincible" barbed wire top section. 
When additional geothermal plants are constructed, each plant will be located adjacent to its own producing wells. The plants will be adequately separated so that there will be no interference between adjacent plants.

\section{ENERGY CONVERSION SYSTEM}

Drawing 7523-E-3215B is a piping and instrumentation diagram for the system which converts the thermal energy in the reservoir fluid into electrical energy. Geothermal fluid is pumped into the plant by the resource company. The reservoir fluid is exchanged with the working fluid in the brine/hydrocarbon exchangers. The cooled brine is then returned to the resource company for reinjection.

Specifications for the major exchangers are included in Section 5 . The brine/ hydrocarbon exchangers are fixed-tube sheet design with single pass flow on both sides. Construction is TEMA-C without cross baffles. This design provides high shell-side hydrocarbon velocities, high heat transfer coefficients and low pressure drops. Materials are carbon steel. Four exchangers in series have been provided for each parallel stream. Overall transfer rate is about 1,420 watts $/\left(\mathrm{m}^{2}\right)\left({ }^{\circ} \mathrm{C}\right),\left[250 \mathrm{BTU} /(\mathrm{hr})\left(\mathrm{ft}^{2}\right)\left({ }^{\circ} \mathrm{F}\right)\right]$. It is anticipated that the exchangers will be cleaned either mechanically or chemically once per year by an outside contractor. No facilities for cleaning the exchangers have been provided.

The working fluid is vaporized in the exchangers and flows to the turbine. The turbine will be an axial or radial flow unit with an expected efficiency of 85 percent. A general specification for the turbine and generator is provided in Section 5 .

From our contacts with turbine manufacturers, we expect that it will be possible to provide a turbine which will meet beginning and end-of-run conditions with minor or perhaps no modifications. EPRI has issued contracts to prepare preliminary design studies of axial and radial turbines for service in a binary process geothermal plant. The data developed in these studies should provide a definitive answer to the matter of designing a turbine for both conditions. 
The generator is designed to produce 65 MWe with an estimated efficiency of $98 \%$. This capacity is adequate to meet the end-of-run power requirements of the plant and still produce 50 MWe of net power.

The hydrocarbon condensers are fixed-tube sheet design desuperheating condensers with single pass, low finned tubes. Construction is TEMA-C and material carbon steel. The condensers will be installed in parallel overhead of the four horizontal accumulator vessels, two condensers for each vessel except for the fourth vesse1. The seventh condenser will be installed over this vessel with provision for adding one more condenser at a future date.

Six vertical motor-driven pumps in parallel are provided for hydrocarbon circulation. The units are designed with 12 stages and allow for the addition of 2 stages in the future for increased head requirements as hydrocarbon composition is changed to operate with lower brine temperatures. Vertical design satisfies the NPSH and head requirements for the hydrocarbon fluid operating at its vapor pressure in the accumulators. No booster pumps are required for the vertical pumps. Materials of construction are carbon steel.

The hydrocarbon inventory is contained in four accumulators and a storage tank. A vertical 3-stage pump functions as a hydrocarbon makeup and transfer unit between all of the vessels.

A pump out compressor with suction knockout drum is provided for hydrocarbon vapor removal from the accumulators to facilitate vessel maintenance, and minimize hydrocarbon emissions to the surroundings. Piping is provided to permit transfer of the vapor to another accumulator, a condenser, or the storage tank.

At the middle-of-run condition, when the composition of the working fluid is changed, the following equipment additions to the plant will be required:

Hydrocarbon/brine heat exchangers - 1 parallel line of 4 units in series 
Hydrocarbon Condensers

Hydrocarbon circulation pumps
-1 exchanger shell in parallel

-1 pump in parallel

Also, to provide the required increase in head, the six start-of-mun, 12-stage vertical hydrocarbon circulation pumps will require two additional stages. The turbine will require only a change of blading. No further changes will be required at the end-of-run as the brine temperature decreases to $163 \mathrm{C}$ at the end-of-run. Design pressures of all start-of-run equipment will meet for middle and end-of-run requirements. Piping as shown on the piping and instrument diagram for start-of-run conditions will meet expected requirements throughout the plant lifetime. Additional piping, instrumentation and electrical material required for the equipment will be added when the middle-of-run change over occurs.

COOLING WATER SYSTEM

The cooling water system is shown on piping and instrument flow sheet No. 7523E-3246. The major equipment consists of the circulation pumps, cooling tower, basin, and the make-up water pumps. The water treatment section consists of sand filter, facilities to add acid, chlorine, corrosion inhibitor, and dispersant, and an automatic control that monitors and maintains the quality of the circulating water. The individual equipment specifications can be found under Specifications, Section 5 of this report.

An induced draft cooling tower has been selected. It will consist of seven identical cells with one $200 \mathrm{HP}$ fan per cell. As the brine temperature decreases, heat rejection requirements will increase, and it will be necessary to add 3 more cells to the cooling tower. Space has been allowed on the plot plan for this addition.

Centrifugal, horizontal circulating water pumps were selected for this service because of their low initial cost and high efficiency. Two pumps will provide the required $8.58 \mathrm{~m} / \mathrm{sec}$. $(136,085 \mathrm{gpm})$ at $303 \mathrm{kPa}$ (44 psi) head. An additional pump will be furnished to function as a spare. As the brine temp- 
erature decreases and the process conditions change, a fourth pump will be added. The pump pit has been designed for the addition of the fourth pump.

A vertical type make-up water pump has been selected. The water will be taken out of an irrigation canal and, after a preliminary screen filtration, will be pumped through sand filters on its way to the cooling tower basin. The makeup water rate was determined based on evaporative and drift loss estimates and a blowdown rate consistant with a four fold concentration of solids in the cooling water.

Sand filter vessels, filled with sand and anthracite, will remove silt and other particles in suspension. An automatic system will divert flow from one vesse1 at a time and reverse the flow of water in order to clean the filtering medium. The sediment will be discharged into a pit for disposal.

The quality of water will be monitored continuously by an analyzer in the water treatment automatic control system. Sulfuric acid will be added to the makeup water in a baffled mixing trough. The chlorine will be sparged into the water at the discharge of the circulation pumps. Corrosion inhibitor and a dissolved solids dispersant will be diluted in mixing tanks and the solutions fed to the basin. In addition, the water treatment system will control the cooling water blowdown rate.

PLANT AND INSTRUMENT AIR SYSTEM

The plant and instrument air system is shown on piping and instrumentation flow sheet No. 7523-D-3221. Separate air systems are provided for plant and instrument air. A manual cross over is provided between the systems so that an operator could use plant air in the instrument air system if the instrument air system should fail.

The instrument air compressor will have non lubricated pistons to prevent oil contamination of the instrument air system. 
The compressed instrument air will be cooled and condensables removed before it flows to a surge drum. Further separation of condensables occurs in this drum. The air then flows through an all-purpose filter to remove other foreign materials. The air is then dried to a $-40 \mathrm{C}$ dewpoint in regenerative solid desiccant beds, and filtered before being used.

The plant air system is similar to the instrument air system except that the conpressor is of the lubricated type, and no air dryer is provided.

\section{FLARE SYSTEM}

This system, shown on accompanying Drawing No. 7523-D3222, may be purchased as a packaged unit.

A flare system has been provided to burn any hydrocarbon vapors escaping through plant relief valves. If process pressures increase above the pressure ratings of operating equipment, the pertinent relief valves will open and release vapors into the flare system. This system has been designed to handle the limiting load of $104,325 \mathrm{~kg} / \mathrm{hr}(230,000 \mathrm{lbs} / \mathrm{hr})$ of hydrocarbon vapor that would be generated in case a fire occurs in the condenser-accumulator section of the plant. The vapors will be routed from the relief header into a knockout drum where condensables, if any, will separate by gravity. The vapors will then activate a flow sensor that will in turn start the pilot ignition cycle. The vapors will be temporarily accumulated in a water seal drum until pressure in the relief line breaks the water seal. The vapors will then proceed up the 43 meter ( 140 foot) flare stack and be ignited by the pilot flame. The hydrocarbon will generate smoke as it burns as no additional air will be forced up the stack. Since this system will operate only during emergencies the additional expense of installing and operating air blowers at the stack base was not considered justifiable.

The height of the stack will provide appropriate dispersion of the gaseous effluents, such that ground level concentrations of any pollutant generated will be below regulatory limitations. 
To prevent accumulation of hydrocarbons heavier than air, a hydrocarbon analyzer with alarm mounted on the control panel, will be installed at the foot of the flare stack.

\section{FIRE WATER SYSTEM}

The fire water protection system in the plant relies on a physical separation of potential fire areas. These areas coincide with the four major functional areas listed above under Plant Layout. Their physical separation permits the isolation of each area from the others in case of fire. Consequently, the fire water system has been sized to satisfy the largest requirement of any area. This requirement was found to be $0.189 \mathrm{~m}^{3} / \mathrm{sec} .(3,000 \mathrm{gpm})$ at the condenser-accumulator section. This flow of water will be provided by two pumps started in automatic sequence in order to maintain a $689 \mathrm{kPa}$ (100 psia) pressure in the line. One pump will be driven by an electric motor, the other one by a diesel engine. A spare diesel engine driven pump has been provided. A jockey pump will maintain the pressure in the line during normal operation of the plant.

To insure an appropriate fire water coverage throughout the plant, the system includes a loop header along the periphery of the plant, six hydrants, six $0.0315 \mathrm{~m}^{3} / \mathrm{sec}$. (500 gpm) monitors, and deluge systems for the condenseraccumulator area, the brine/hydrocarbon exchanger area, and the hydrocarbon storage area.

The fire water supply is taken from the cooling tower basin. This supply will last about three hours at the maximum fire water flow rate without make-up. The rate of the water make-up to the cooling tower is about equal to the consumption of the fire water system. 


\section{ELECTRICAL SYSTEM}

The main plant electrical system is depicted in Drawing No. 7523-D-3601. A $3600 \mathrm{RPM}, 76.5 \mathrm{MVA}$ synchronus generator produces power at $13.8 \mathrm{KV}$. The power is fed to the $4000 \mathrm{~A}$ main switchgear where in-plant power is removed. The net remaining power, approximately $50 \mathrm{MWe}$, flows through the $13.8 / 33 \mathrm{KV}$ main transformer and main breaker to the $33 \mathrm{KV}$ electric utility system substation.

Two in-plant electrical systems are included in the plant design. A $4160 \mathrm{~V}$ system for motors above 200 horsepower, and a $480 \mathrm{~V}$ system for lower horsepower motors, lighting and controls. The 4160V, 20 MVA system is shown in Drawing No. 7623-D-3602. Power from the main switchgear flows to a 3 phase, $13.8 \mathrm{KV} / 4160 \mathrm{~V}$ transformer, Substation B. High voltage power from Substation $B$ is used to drive the hydrocarbon circulating pump and circulating water pump motors.

The 3 phase $480 \mathrm{~V}, 2500$ KVA in-plant system is outlined in Drawing No. 7523-D3603 and D-3604. A $13.8 \mathrm{KV} / 480 \mathrm{~V}$ transformer, Substation C, feeds power to the $480 \mathrm{~V}$ switchgear. Two motor control centers, MCC-A and MCC-B are fed from the $480 \mathrm{~V}$ switchgear. Power from MCC-A and $-B$ will drive cooling tower fans, water treatment system motors, air compressors and make-up pumps, provide indoor and outdoor lighting and instrumentation and control power.

\section{PIPING}

The plant site has been divided as shown on Drawing 7523-E-3261 to designate piping area locations for preparation of piping drawings. Preliminary piping plan drawings for Areas $A, B, C, D$ and $F$ have been prepared, and are shown on Drawings 7523-E-3262 and 3265 and 3269. Piping sections for Areas $B$ and $C$ are shown on Drawings 7523-E-3268 and 3269 . 
The above piping drawings were prepared in order to establish major equipment and piping locations which provide a basis for estimating plant construction costs. The drawings are preliminary in nature, therefore, piping and equipment locations established during final design may vary somewhat from those shown.

Piping design specifications are included in Section 6 of this report.

\section{INSTRUMENTATION AND CONTROL}

Chevron has stated that the maximum variation in well flow rate should be no more than \pm 15 percent. While well flow may. be reduced quickly (on the order of seconds) the rate must be increased slowly (on the order of minutes). Because of this limitation it appears that the plant should be operated as a base-load facility, although means for emergency load-shedding must be provided.

Preliminary control is based on the premise that plant output will vary with power demand. Consequently, a load control with manual set point is included for the generator, controlling the hydrocarbon flow rate to the turbine. Brine flow rate is controlled by the temperature of hydrocarbon vapor entering the turbine. Adjustment of hydrocarbon and brine flow rates to each parallel train of hydrocarbon/brine heat exchangers to achieve balance is manual. Adjustment of hydrocarbon and cooling water flow rates to each parallel hydrocarbon condenser is also manual.

The plant will include a system for quick and orderly emergency shutdown of the turbine under conditions such as overspeed, load shed, excess vibration, low oil pressure or any other condition which could damage the turbine or generator.

Major changes in demand will require manually starting up or shutting down of one or more of the hydrocarbon circulating pumps and perhaps cooling tower fans. 
The plant instruments and controls are shown by symbol on the Piping and Instrumentation Flow Diagrams. Drawing No. 7523-D-3258 is provided in this section to define these symbols.

Instruments for supervision of the plant will be centralized at the main control panel. The panel will have a semi-graphic section with color-coded symbols illustrating the complete process. Indicators, recorders, controllers, motor control stations, etc., will be arranged logically to facilitate overall control of the plant operations from this location.

The panel will include an annunciator alarm system connected to a network of sensors which continuously monitor significant process variables throughout the plant. If one or more off-normal conditions occur, the system will immediately alert the plant operator (by audible \& visible signals) and will identify the type and location of each condition in effect.

A comprehensive data logging system has been included to provide a maximum of information on process variables during plant operation. In addition to aiding plant operation, the data should prove beneficial in the design or refinements thereof for future units. The computor data logging terminal is designed so that it be used for additional geothermal units constructed at the Heber reservoir.

Hydrocarbon analyzers will be installed in the heat exchanger brine outlet and the hydrocarbon condenser cooling water outlet to check for exchanger tube leakage.

The process instrument systems will be electronic with 4 to 20 milliamp transmission signals. Panel mounted instruments for these systems will be miniature types.

The control panel will be a vertical free-standing unit of welded steel construction. It will be shop-fabricated and tested completely before shipment 
to the jobsite. No process fluids will enter the panel. Electrical power at the panel will be limited to nominal 120 volts.

Automatic control valves will be pneumatically operated, each valve having a current-to-air converter which accepts a 4-20 ma input signal and develops a proportional pneumatic output to position the valve. All control valves will have provisions for positive failure in specified positions (open or closed) in event of an electric or pneumatic power failure.

Field-mounted instruments will be weatherproof and suitable for the electrical classifications of the areas in which they are located.

Low voltage DC signal wires (4-20 ma, thermocouples, etc.,) will be twisted pairs and will be run in separate conduit and raceways from AC wiring. Thermocouple extension wires will be continuous from the primary element to the cold junction.

Equipment protection will be provided by relief valves and a flare relief header system.

\section{BUILDINGS AND STRUCTURES}

There will be three buildings in the plant. The largest will be the office and control building measuring $85^{\prime} \times 50^{\prime}$ and approximately $15^{\prime}$ high. The interior will be paritioned into a control room measuring 40' $x 35$ ', and additional rooms housing the switchgear, office, instrument and electronic maintenance, and laboratory areas. The building will be located next to the turbine/generator area, will have a door opening to the operating area, and have windows located so that the operators can maintain visual contact with the major equipment areas. A heat pump will supply heating and cooling for all the areas in the building.

As the office and control building will have many visitors, special attention will be given to its appearance through the use of architectural treatment. 
The office and control building will have walls of concrete block. The roof will be bondable build-up type over insulation.

Landscaping around the building as well as the adjacent parking area will be carefully planned with the assistance of a professional landscape architect.

The shop and compressor building will house the plant and instrument air systems, the heavy equipment shop, and locker facilities for the plant employees. The building is approximately $25^{\prime}$ ' $50^{\prime}$. An $1800 \mathrm{~kg}$ hoist and monorail will be provided in the shop area. The building will be a steel Butler-type building.

A third building will enclose the water treating equipment. The building is approximately $20^{\prime} \times 60^{\prime}$. An $1800 \mathrm{~kg}$ hoist and monorail is provided to move the chlorine cylinders. This building will also be a steel Butler-type building.

Structures supporting the condensers and heat exchangers have been designed to distribute the loads at the base to a maximum of $7320 \mathrm{~kg} / \mathrm{m}^{2}\left(1,5001 \mathrm{bs} / \mathrm{ft}^{2}\right)$. Al1 structures have been designed to withstand earthquake accelerations of no less than $0.375 \mathrm{~g}$ coupled to a resonance spectra observed in the $1940 \mathrm{E} 1$ Centro earthquake.

Al1 structural steel will be fireproofed to a height of 11 meters ( 35 feet) abovegrade. Specifications pertaining to buildings and structures are contained in Section 6 of this manual. 


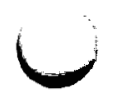

U 


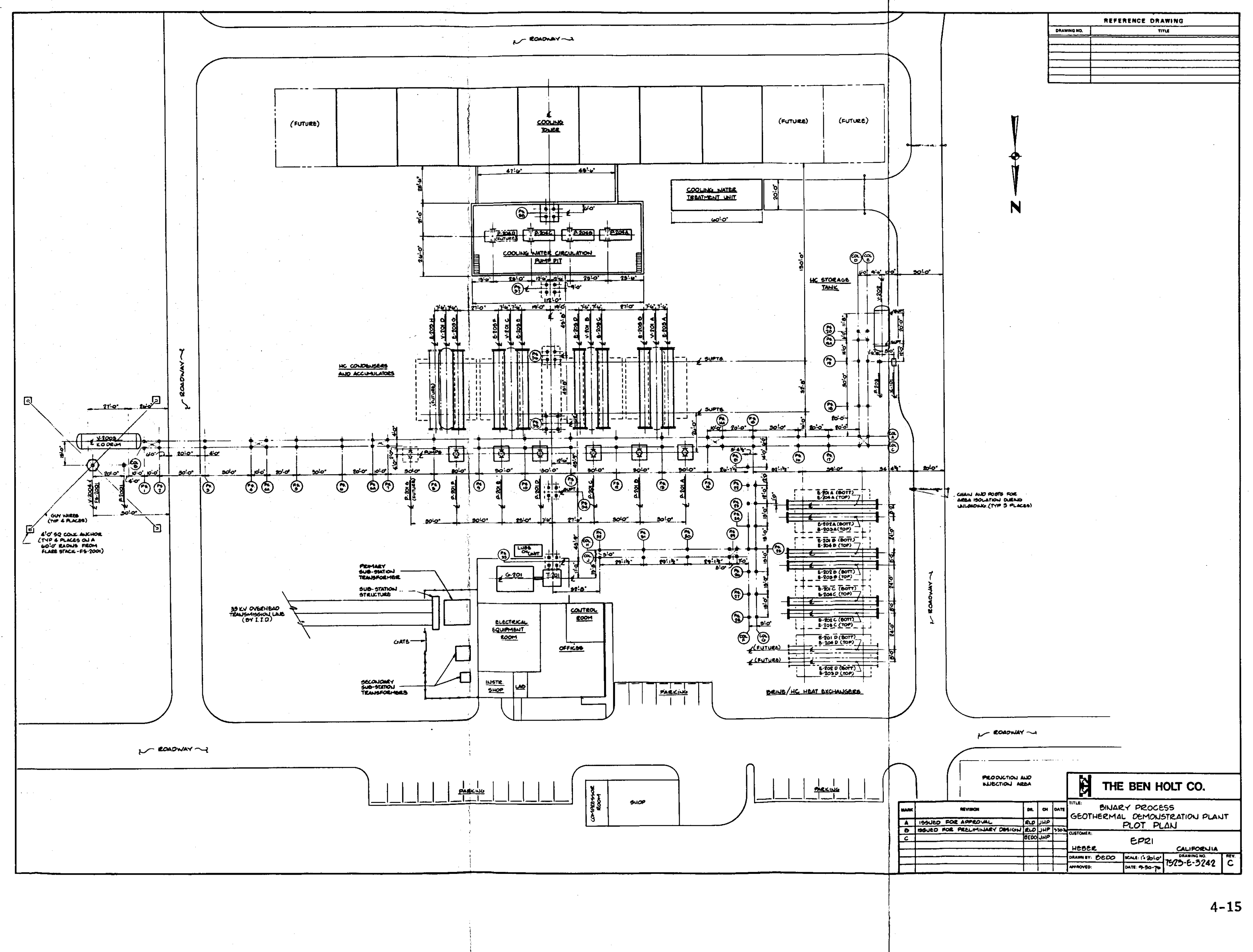


c

C 


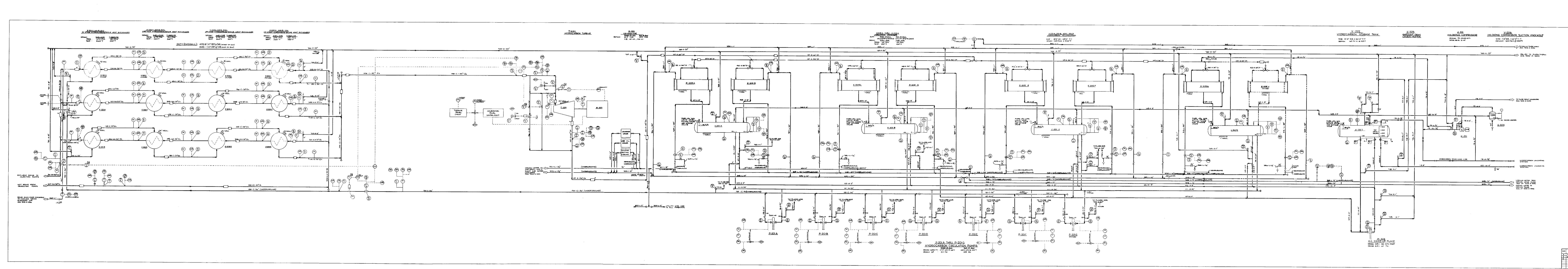

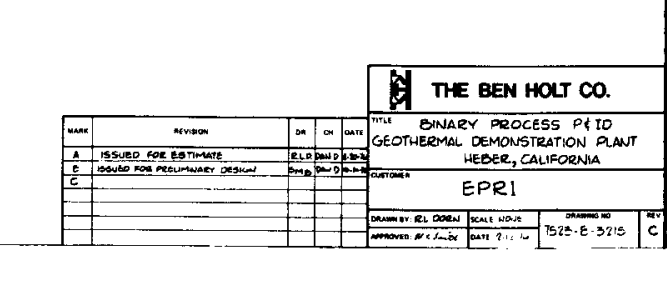




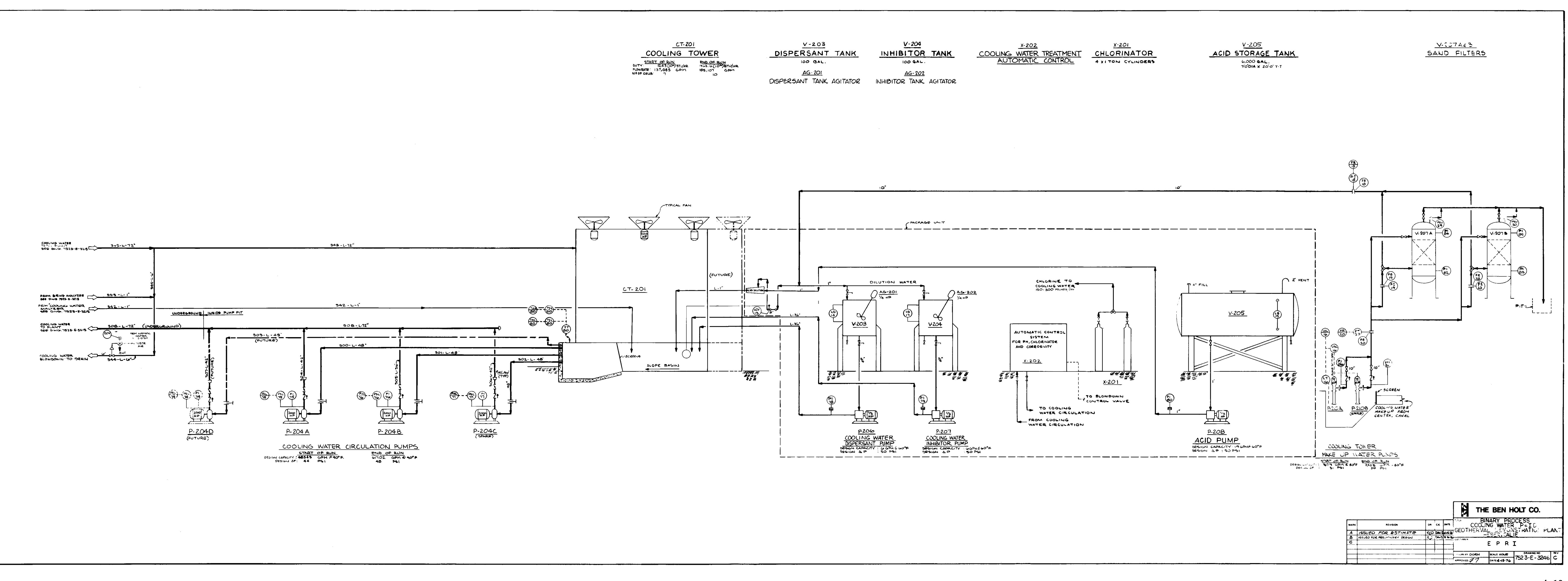




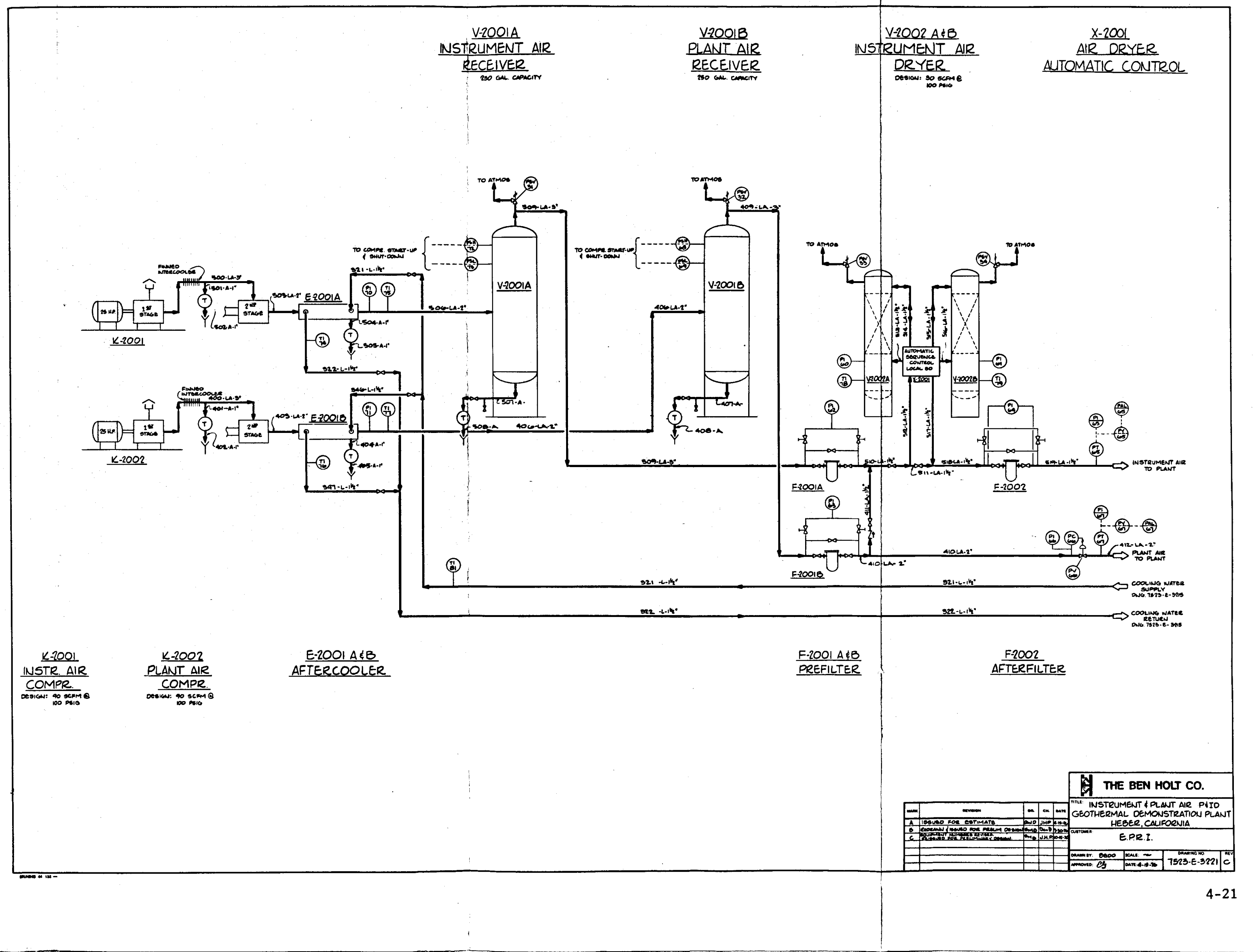


C 


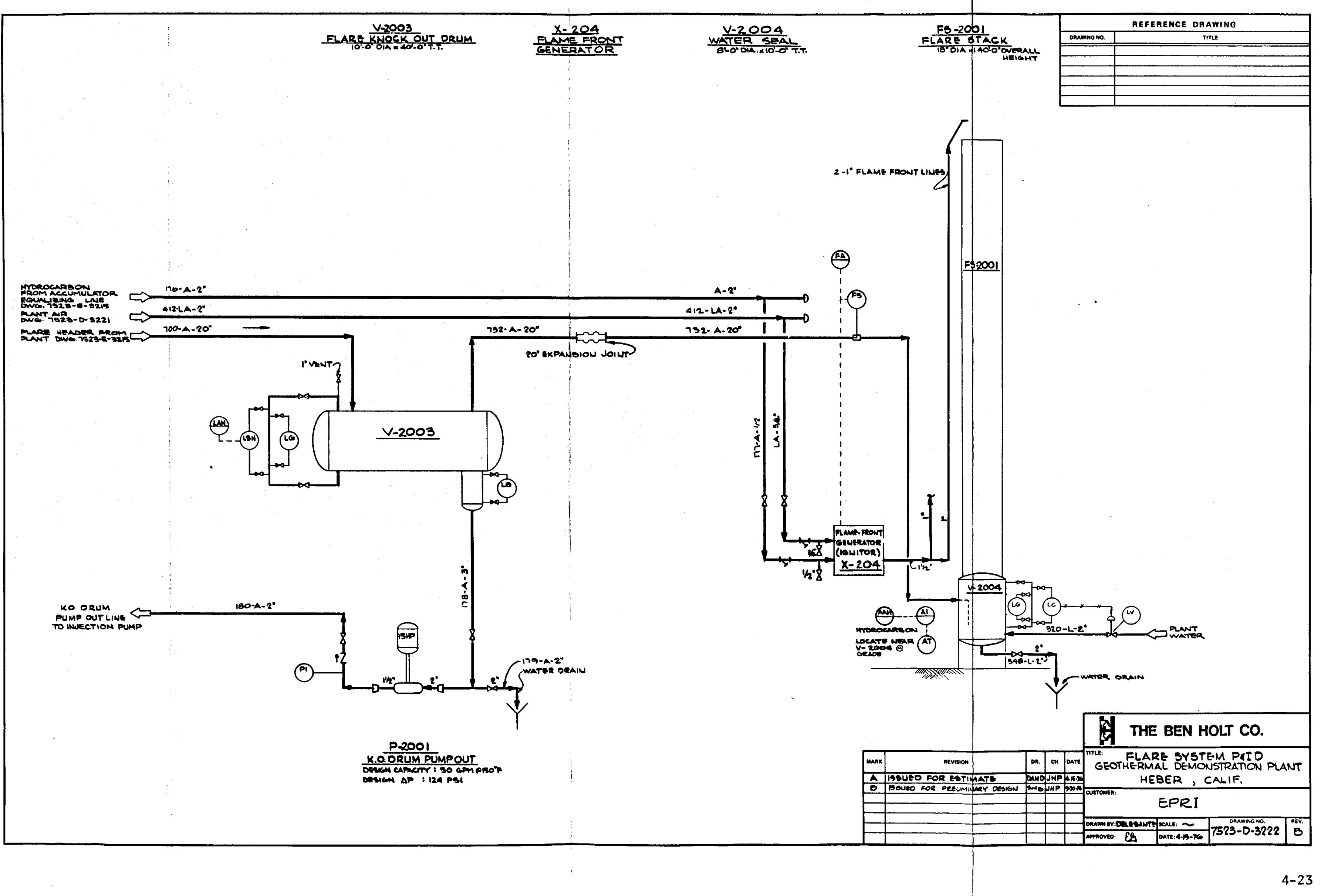


c 


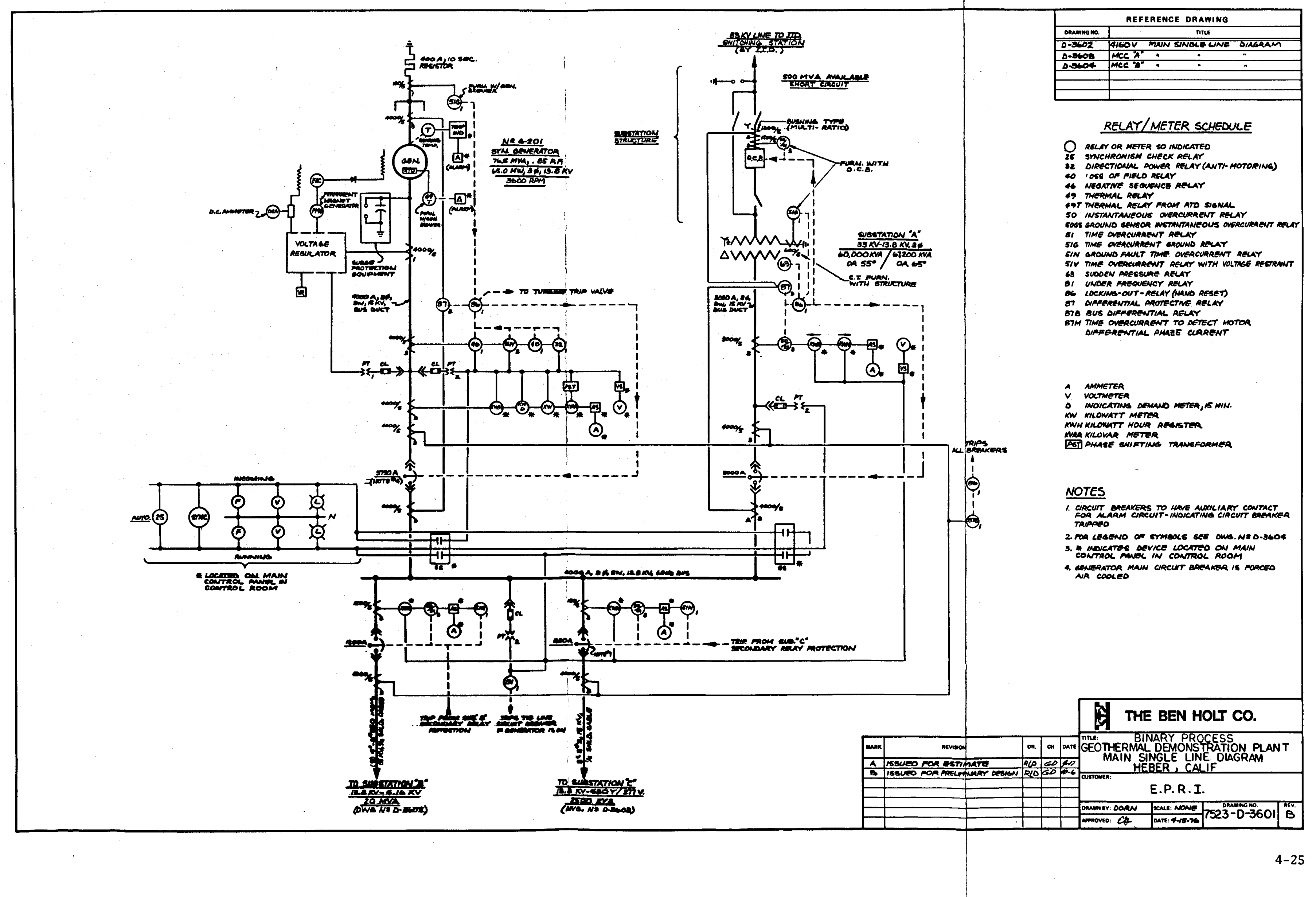





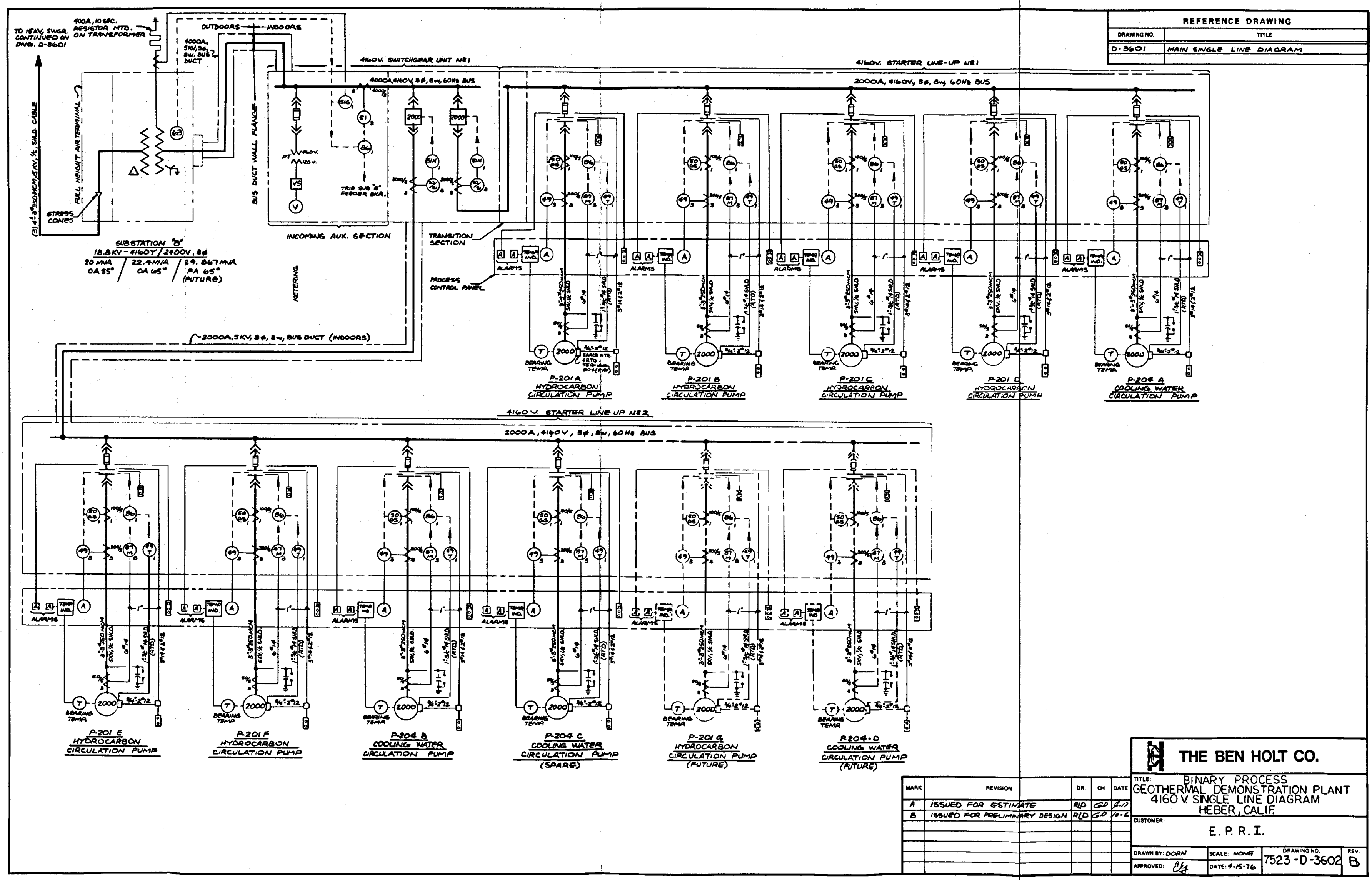


c

C 


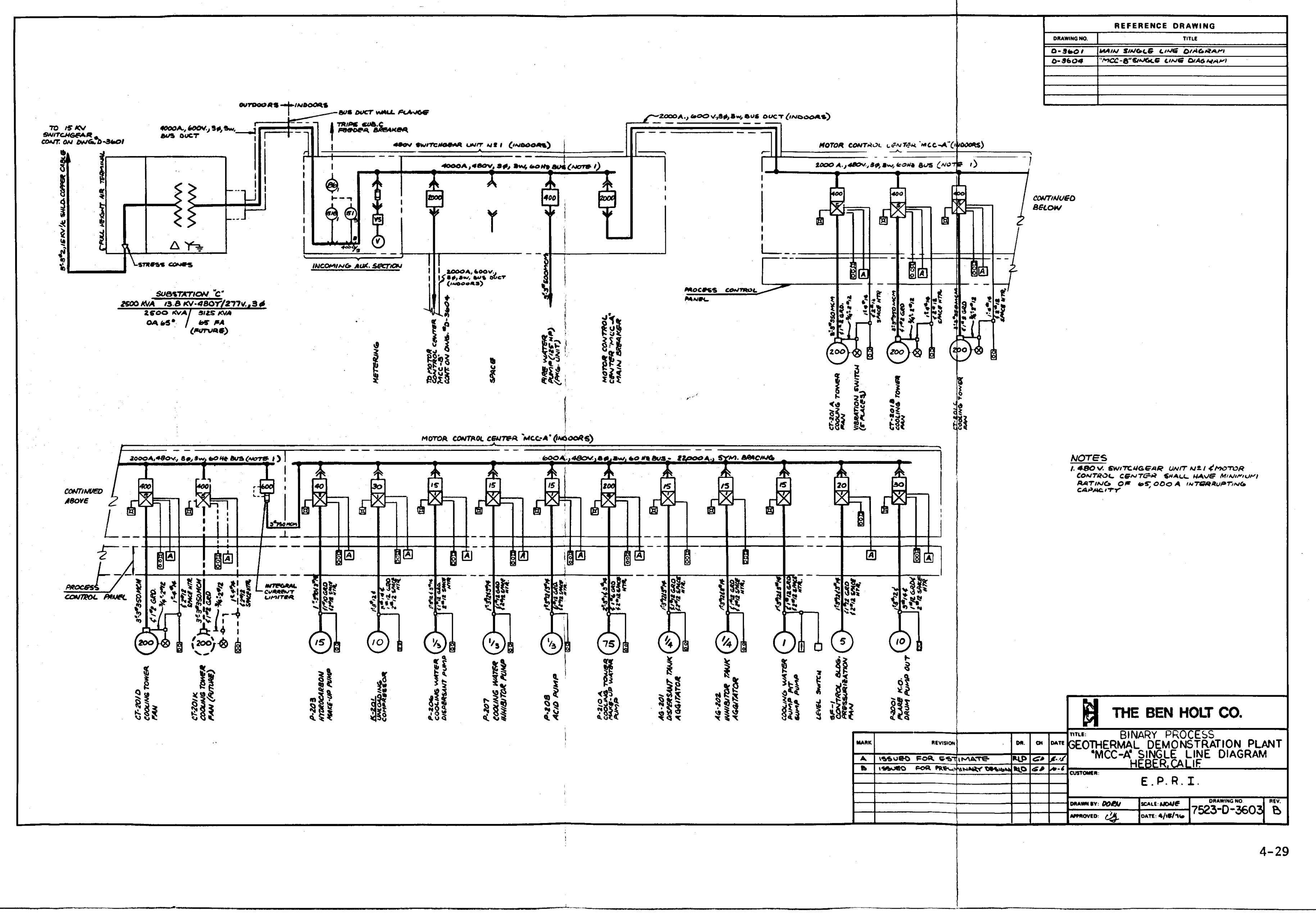


c 


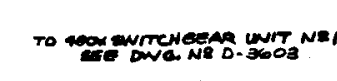

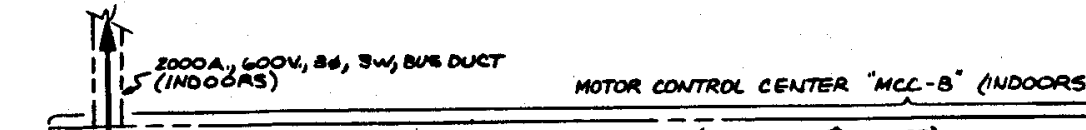

WWTESerL CURRENT LMMITER
Nat5o MCM

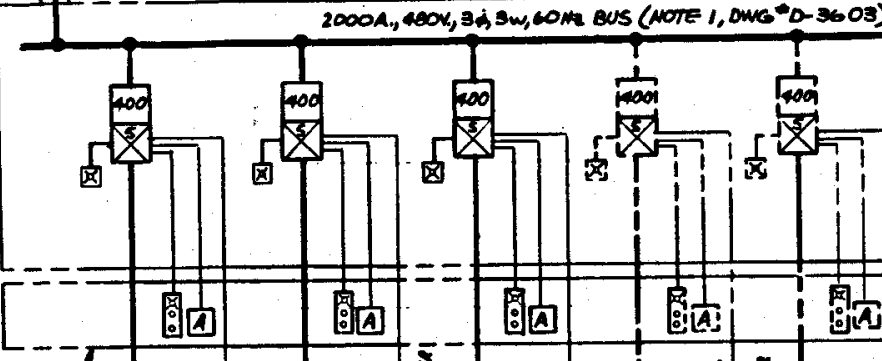

manes

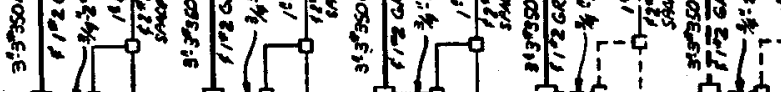

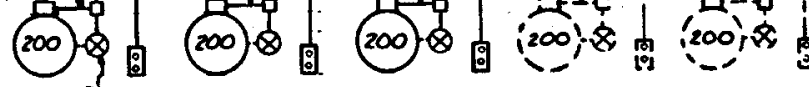

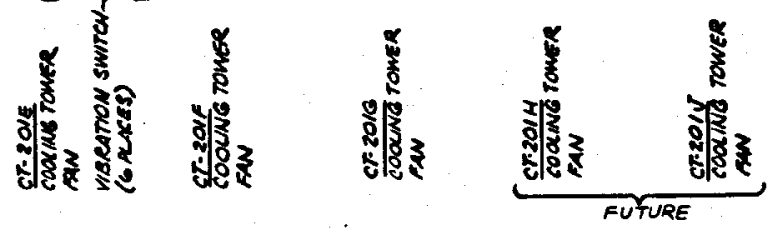

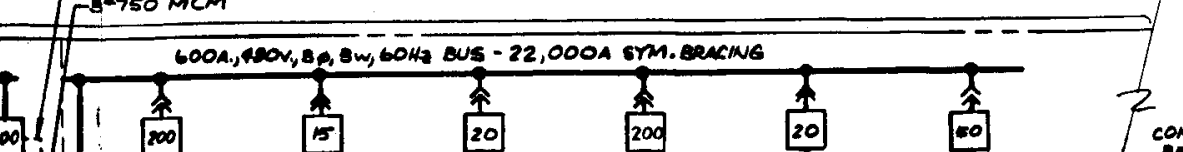
contruves

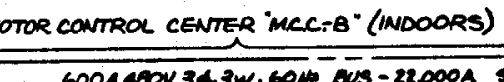
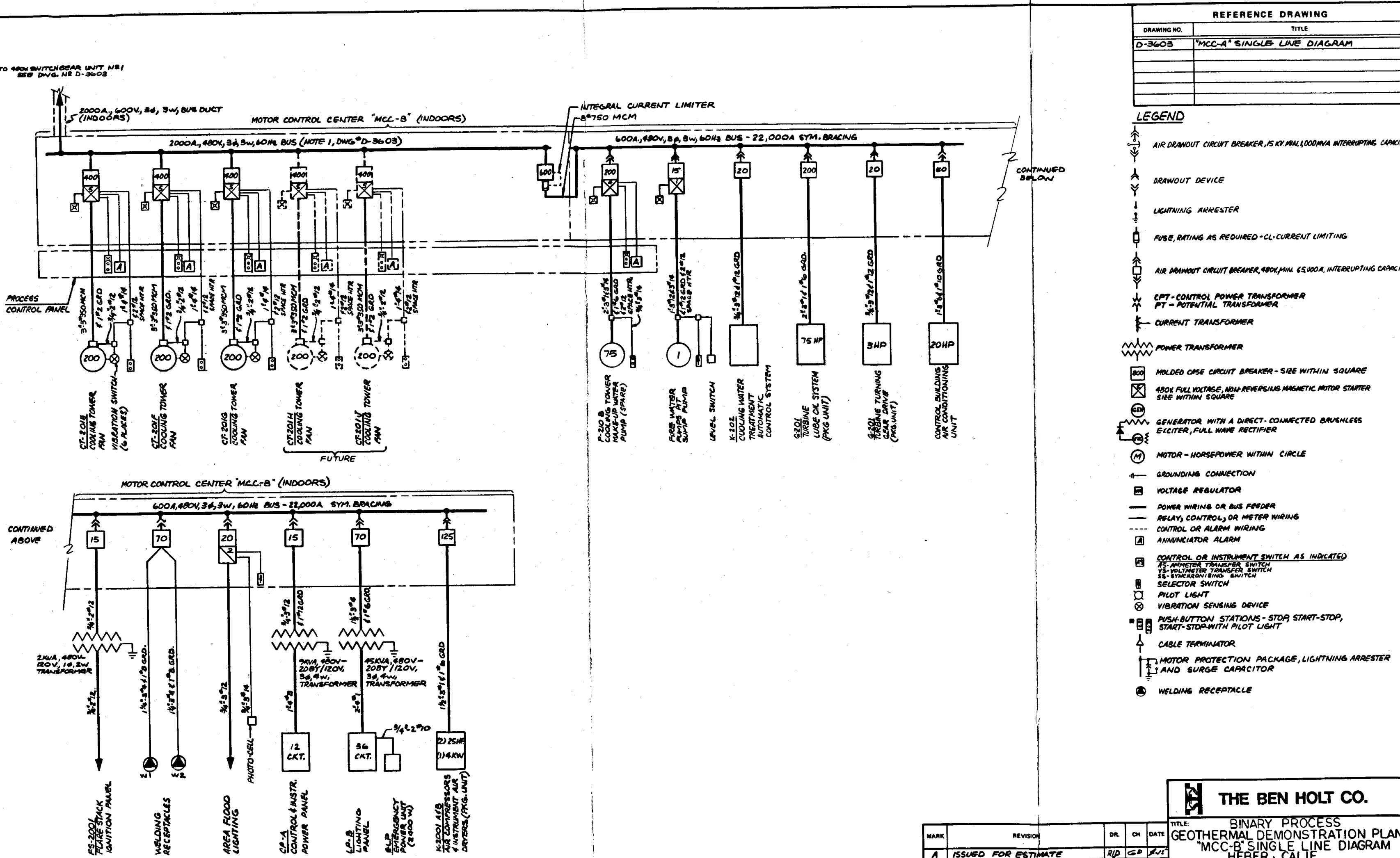

THE BEN HOLT CO.

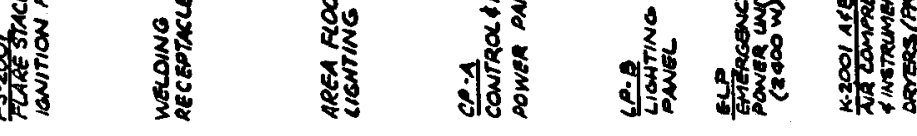


c

C 


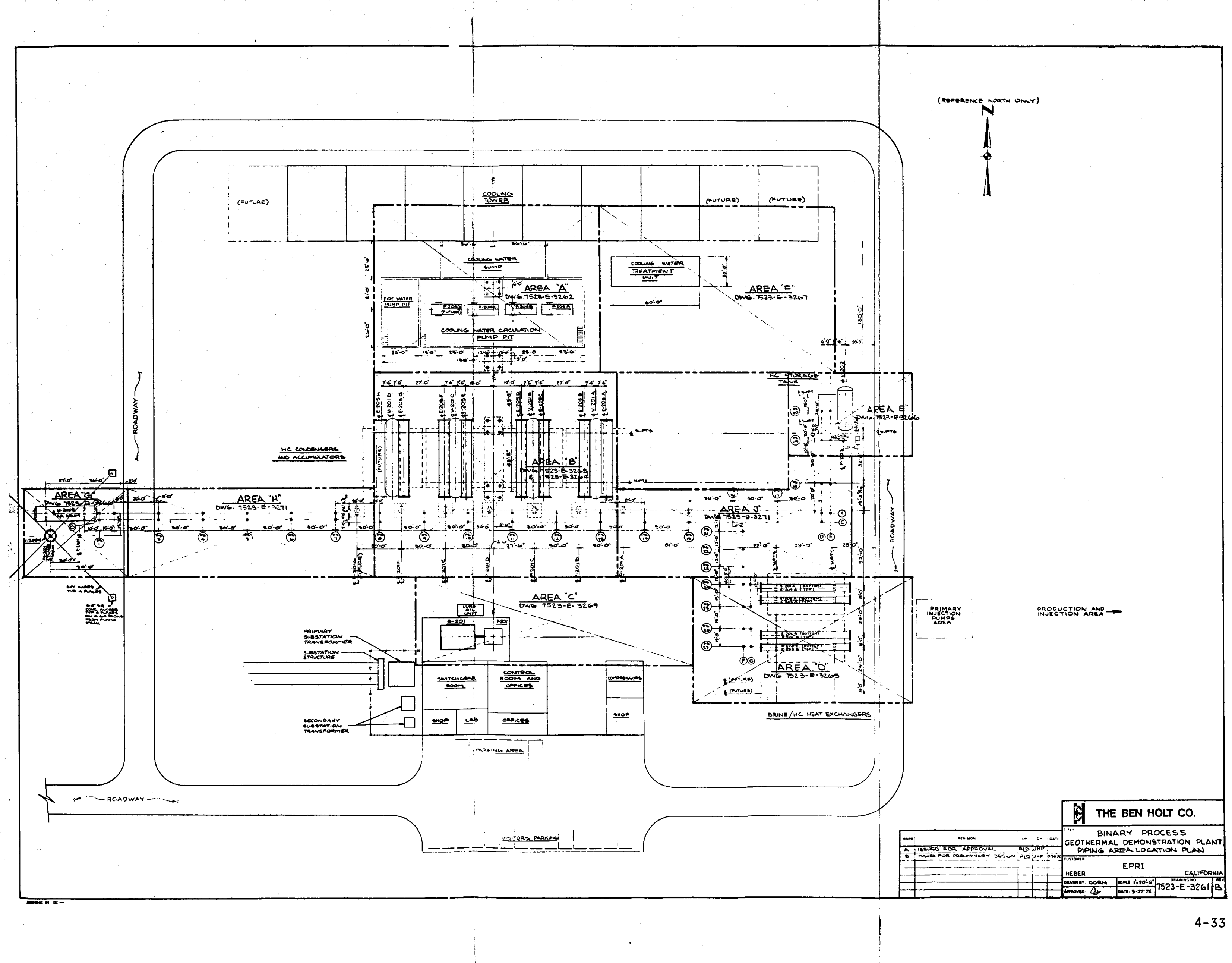


c 


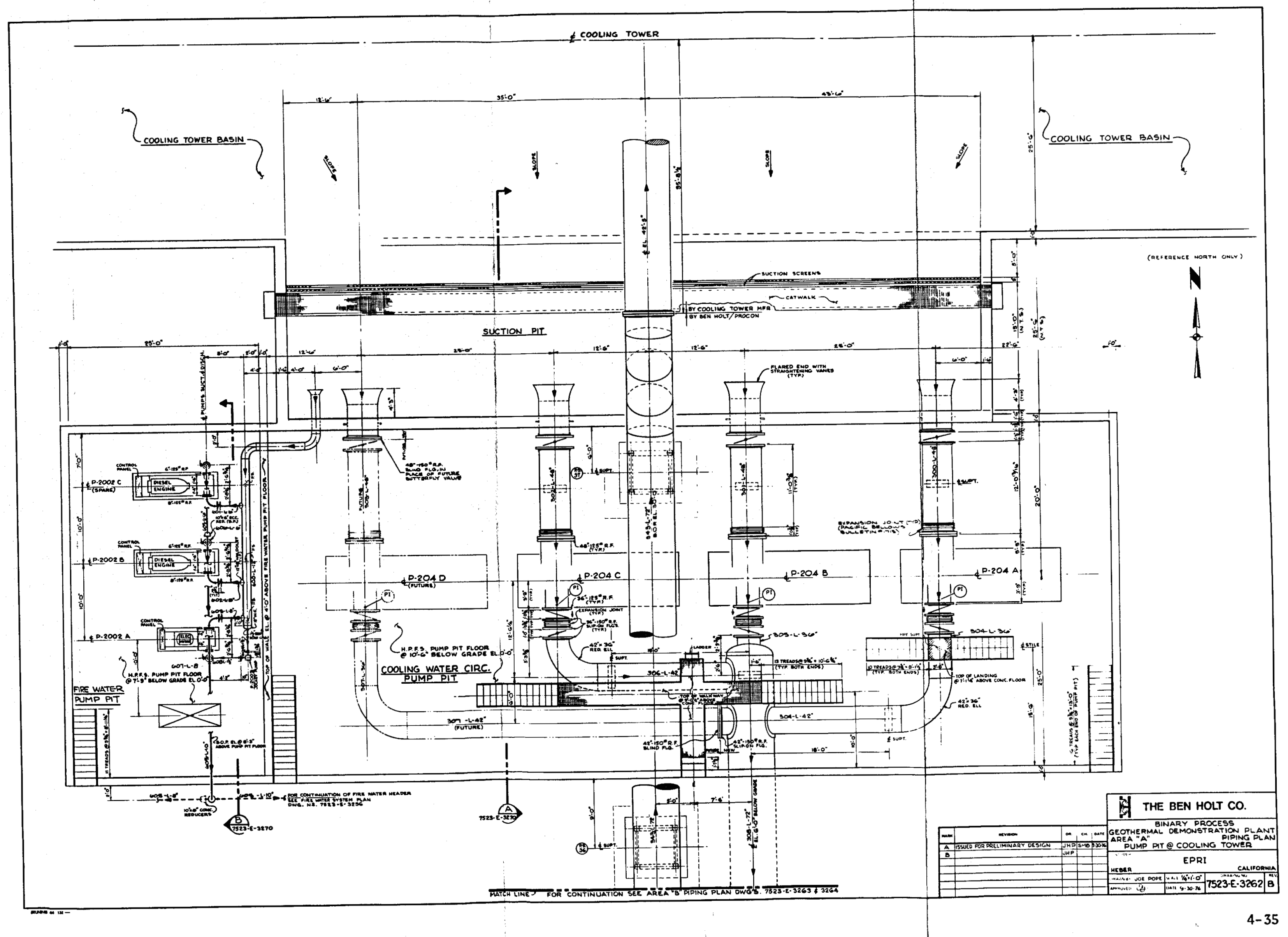


c

C 


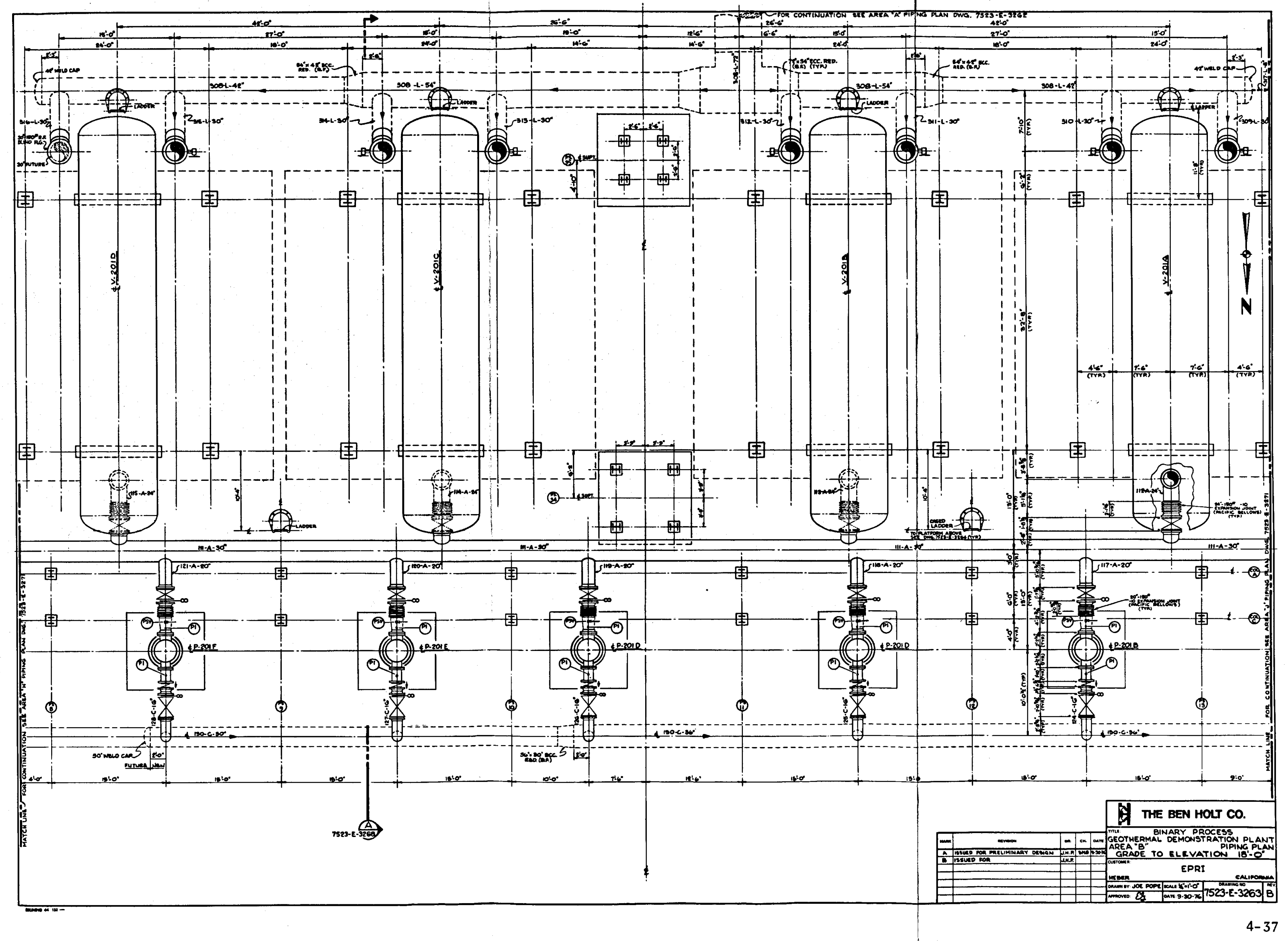


C 


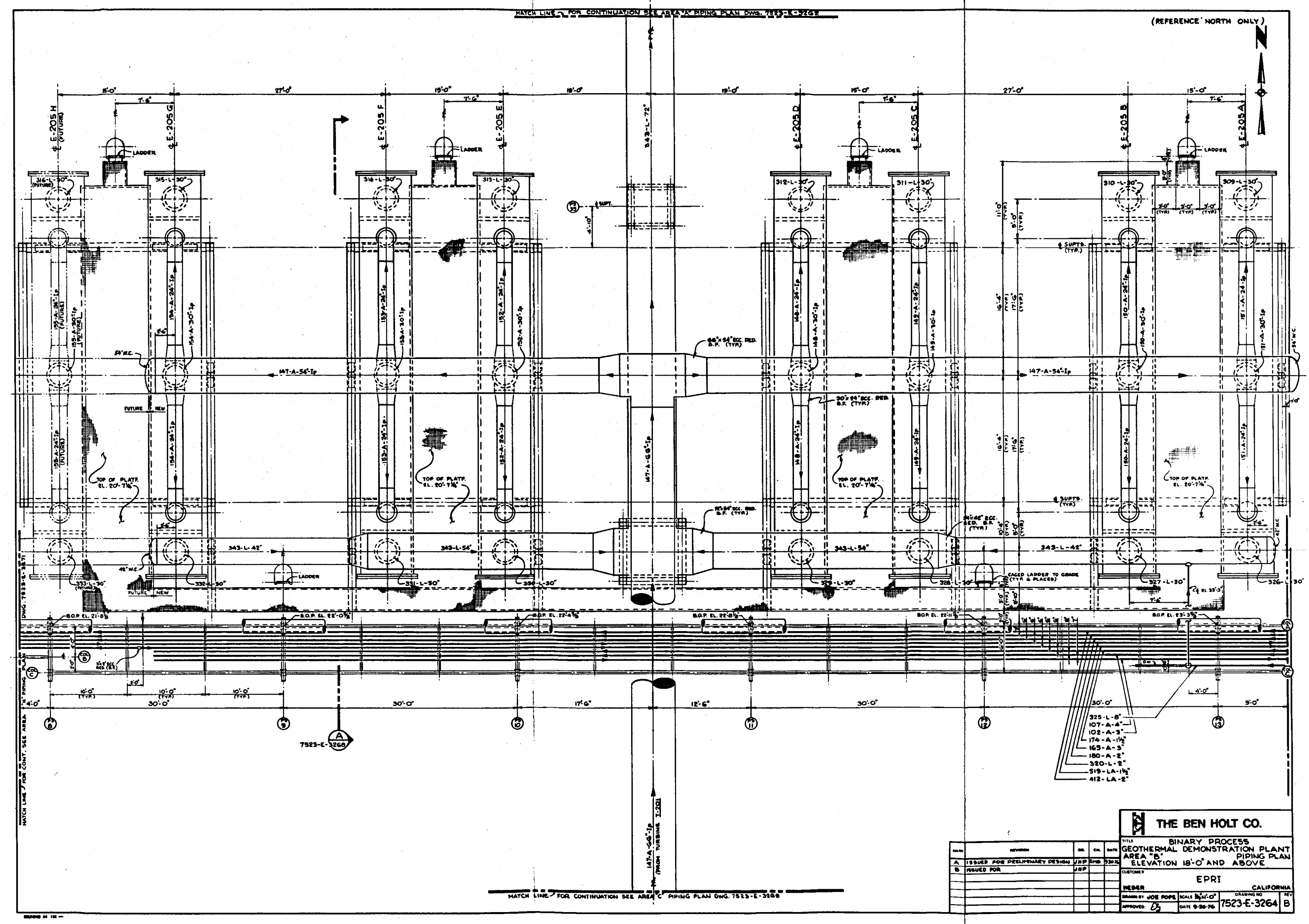




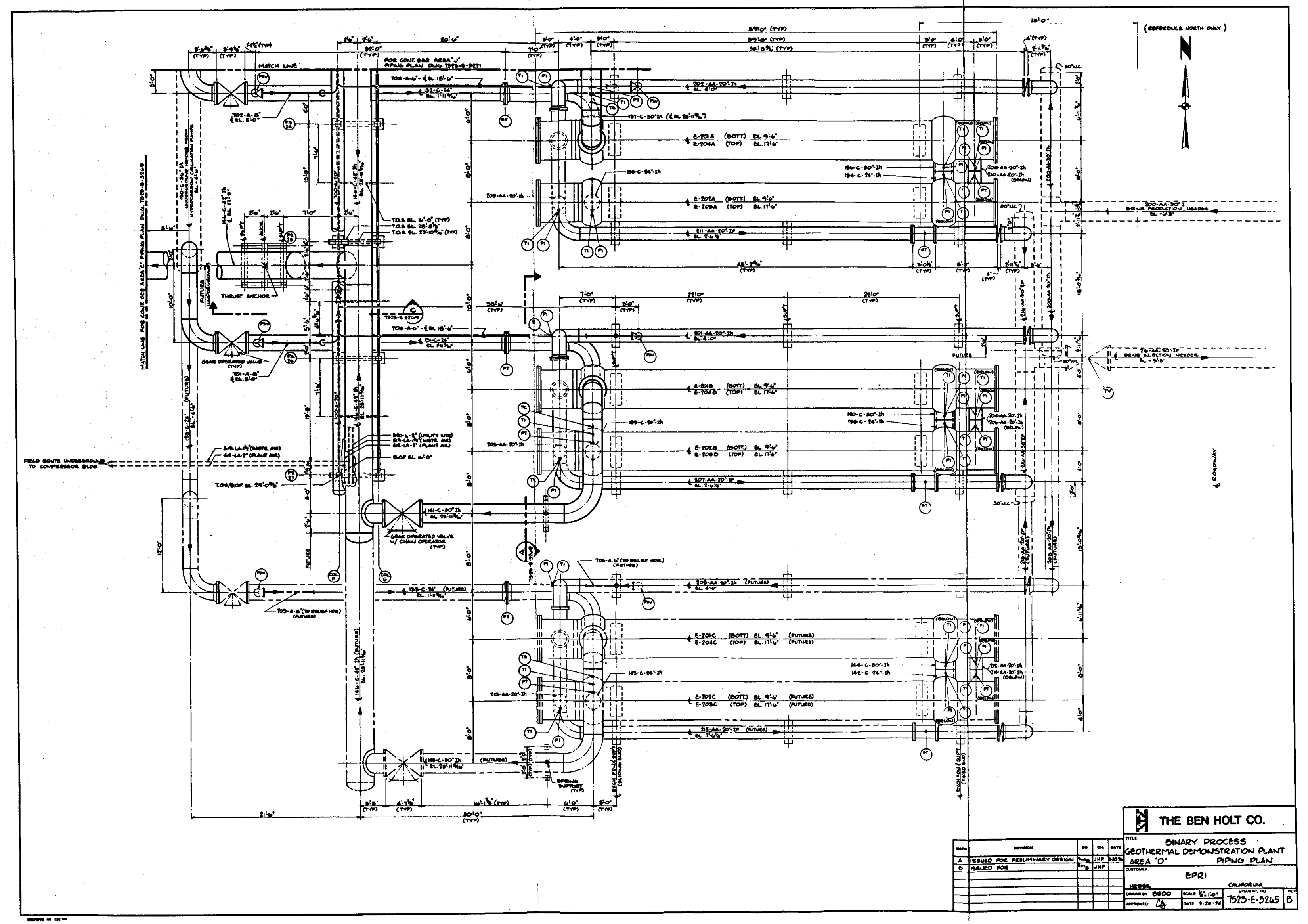


c 


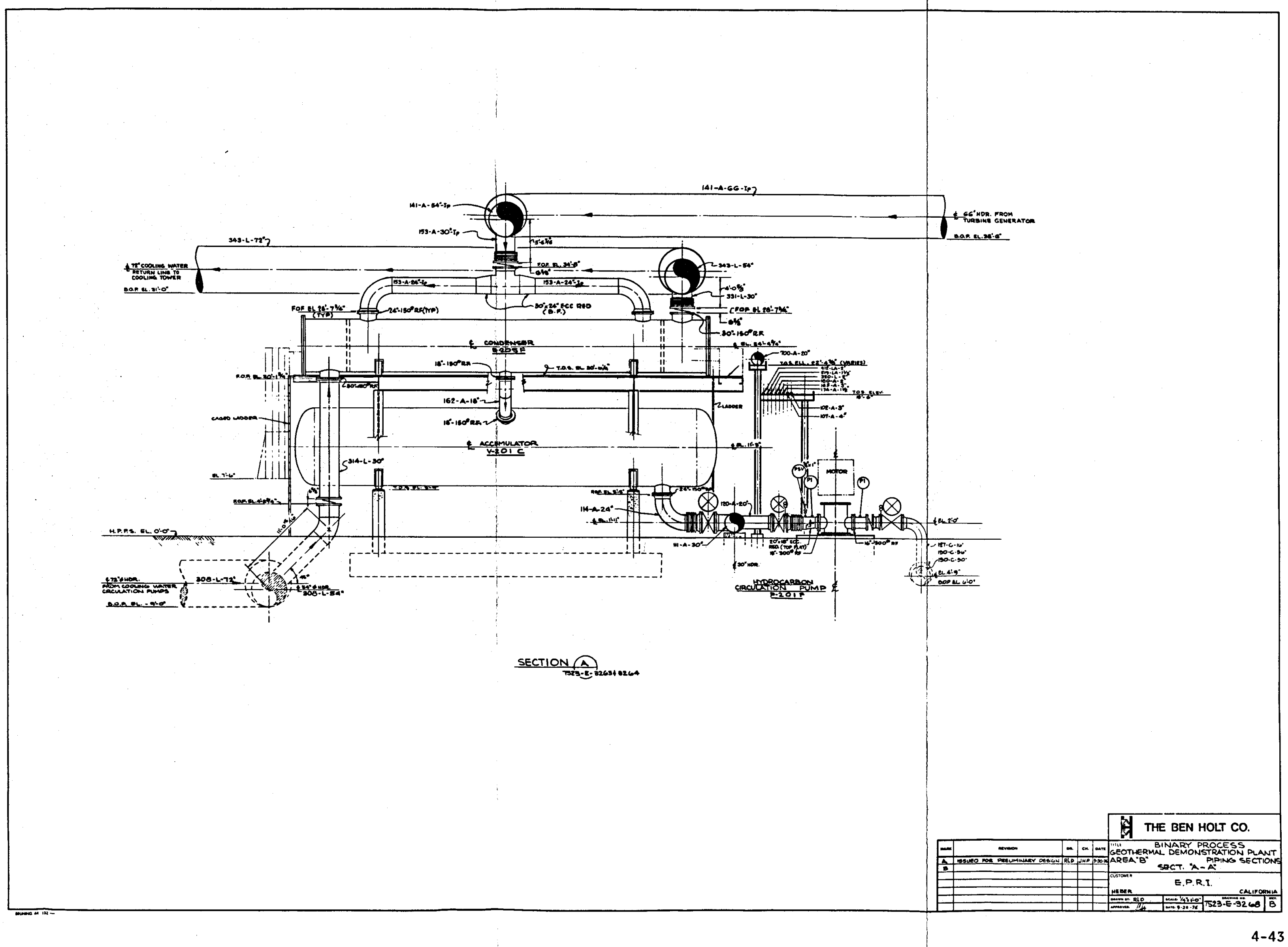


C

C 


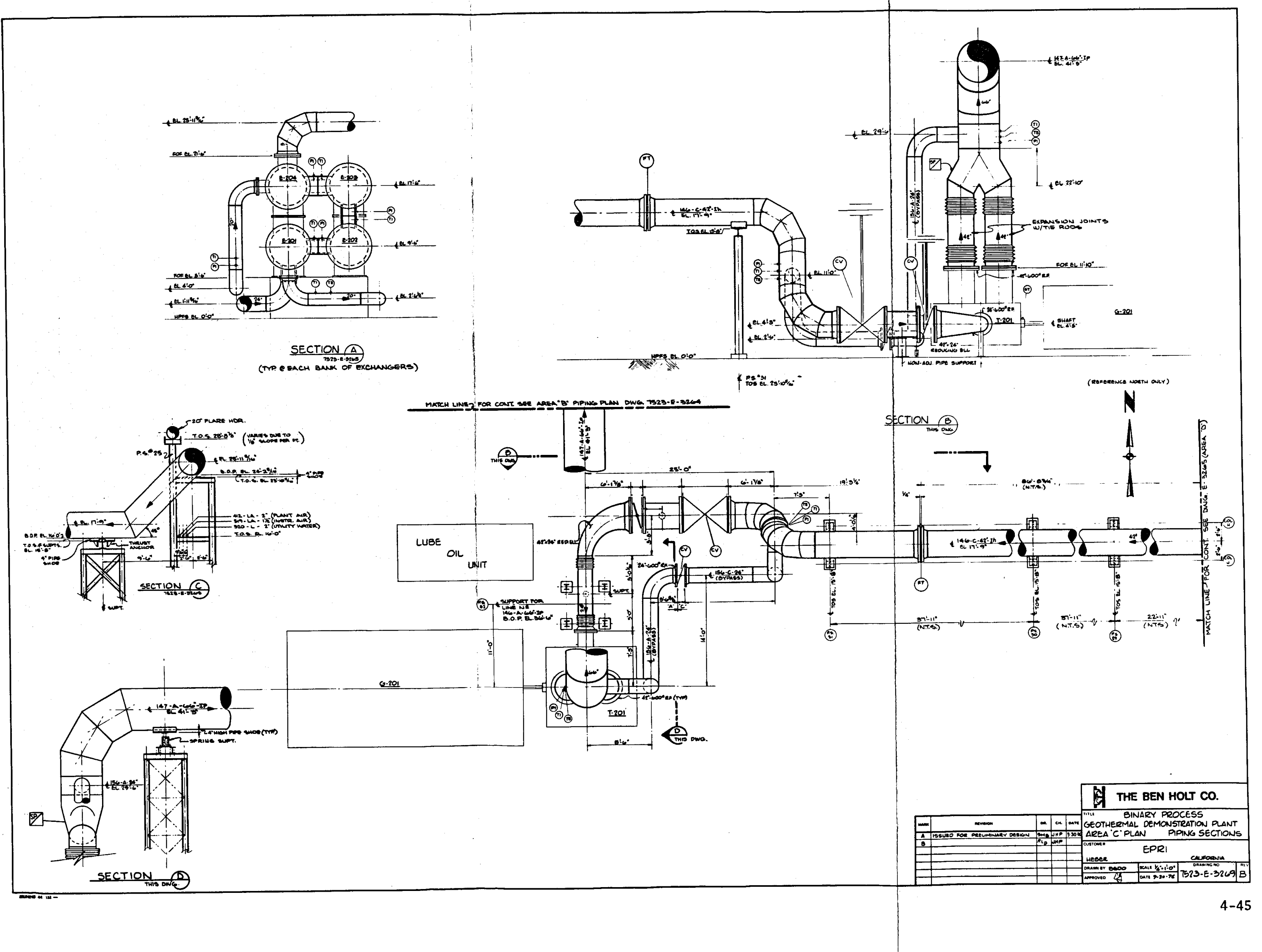


C

C 


\begin{tabular}{|c|c|c|}
\hline \multicolumn{3}{|c|}{ INSTRUMENT SYMBOLS } \\
\hline (A) & $\begin{array}{l}\text { ANACYSIS RECORDER } \\
\text { (WNOCACATE TTPE OUTSIOE SALIOON) }\end{array}$ & (P) PressuRa RICORDER \\
\hline (180) & ANALYSIS RECORDER CONTROLLER & OP PRESSURE RECOEONG CONTROLLR \\
\hline$\Theta$ & 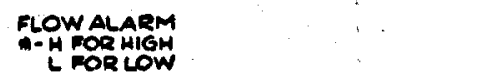 & (3) RUPTURE DISC \\
\hline$\Theta$ & FLOW BLEMENT & (3) PRESSURE SARETr Wive \\
\hline - & A RLW GLASS (OASERVATION) & 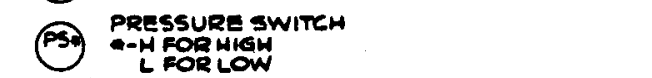 \\
\hline (1) & FLOW INDICATOR & (O) PRESSURE TRANSMITTER \\
\hline & $\begin{array}{l}\text { RLOWINDKCATOR } \\
\text { ROTAMETER TTPE }\end{array}$ & 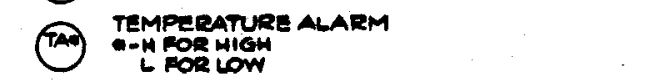 \\
\hline (1) & RLOW INDICATING CONTROLLER & (1C) TEMPERATURE CONTROULR (BLIND) \\
\hline 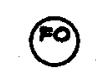 & RLOW ORIFICE (RESTRICTION) & 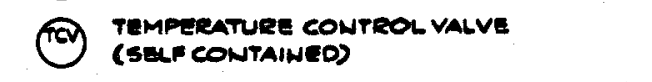 \\
\hline - (-9) & $\begin{array}{l}\text { FLOW METER WITH INDICATOR } \\
\text { APOSITVE DISPACEMENT }\end{array}$ & (1) TEMPERATURE ELEMENT \\
\hline 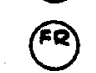 & FLOW RECORDER & (1) Temperature INDICATOR \\
\hline 冈2 & ROW RECOROING CONTROLLER & (10) TEMPERATURE NDTCATING CONTROULER \\
\hline 3 & 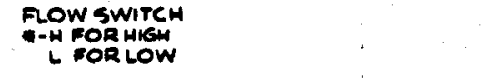 & (10) TEMPERATURE RECORDER \\
\hline$\oplus$ & FLOW TRANSMitTer & (10) TIMPERATURE RECORDING CONTROULR \\
\hline$\circledast$ & MaNuAL CONTROLLER & 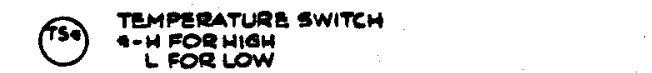 \\
\hline (H) & ManUaL Switer & (1) TEMPSRATURE TRANSMITTER \\
\hline 策 & Manual contro valve & (Ti) TEST THERMOWEIL WITH PLUG \\
\hline$\Theta$ & 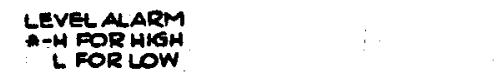 & (4) UNITALARM \\
\hline$(6)$ & LEVELCONTROLER (BLIND) & $\begin{array}{l}\text { (1) TEMPERATURE, FLWW, PRESSURE, } \\
\text { LEVELETC, COUTROQ VALVE }\end{array}$ \\
\hline (6) & OAgE GLASS (LeVEL) & (P) *E/T,IIP, DOOST, ADD, ETC, RELAYY \\
\hline (4) & LEVEL INOICATOR & (X) RUNNING LIGHT \\
\hline (1) & LEVEL INOTCATING CONTROLLRR & \\
\hline$(\bullet)$ & LEVEL RECORDER & \\
\hline 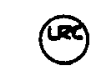 & LEVEL RECOROING CONTROLLER & LOCAUY MOUNTED NISTRUMENT \\
\hline$(4)$ & LEVEL TRANSMITTER & $\ominus$ SOARD MOUNTED INSTRUMENT \\
\hline & 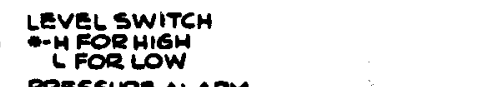 & O instrument with two functions \\
\hline$\circledast$ & 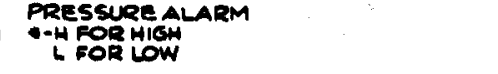 & $\Theta$ instrument MOUNTED BEHIND THE BOARD \\
\hline (c) & PRESSURE CONTROLLER (BLIND) & O-tmese strmboss stmu se 7/w"Dia. \\
\hline$\approx$ & $\begin{array}{l}\text { PRESSURE CONTROL VALVE } \\
\text { (SELFCONTANED) }\end{array}$ & (8) RESET ORRATIO \\
\hline (अ) & PRESSURE DIFFERENTIN TRANSMITTER & (1) INTERLOCK \\
\hline (9) & PRessuph indicator & $\begin{array}{l}\hat{\theta} \text { PURGE OR RUSH CONNECTION } \\
t-\rightarrow \text { BLECTRICAL LEAD }\end{array}$ \\
\hline & 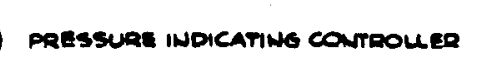 & \# CAPLLAAR \\
\hline
\end{tabular}

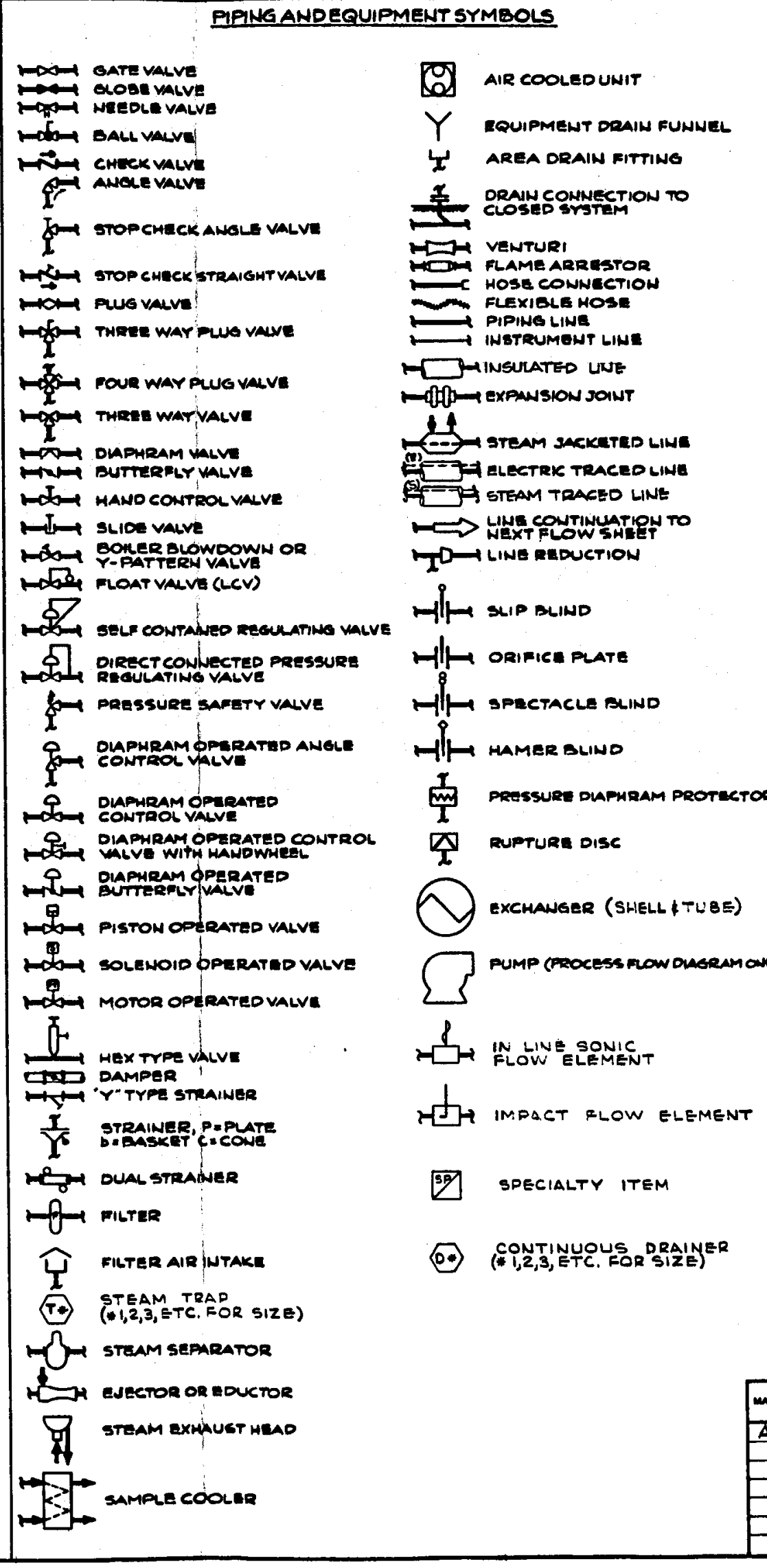
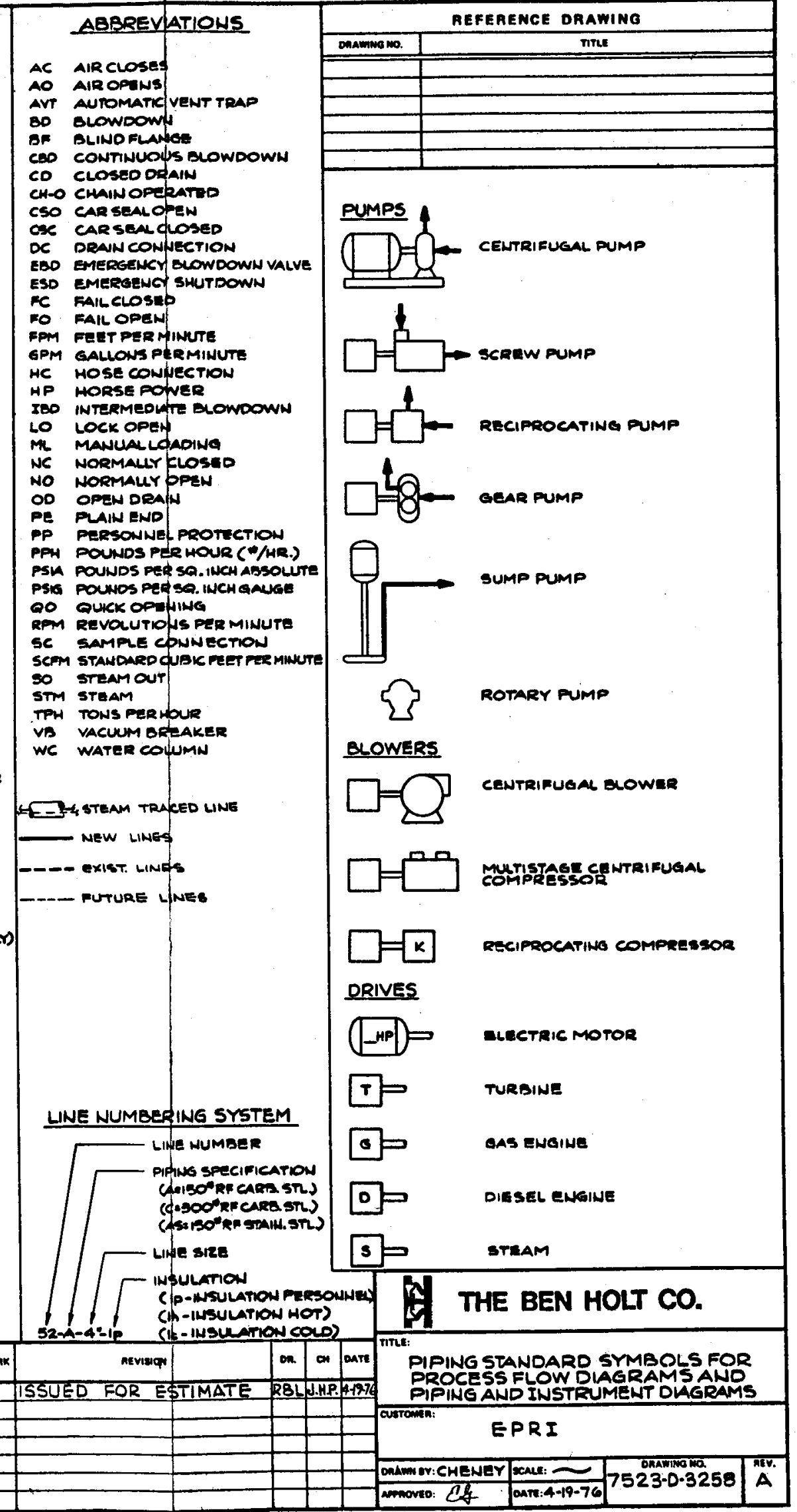
Section 5

EQUIPMENT SPECIFICATIONS 


\section{EQUIPMENT LIST}

SHEET 1 OF 13
REVISION__ DATE

CONTRACT No. 7523

CUSTOMER Electric Power Research Institute

Binary Power Cycle - Geothermal Demonstration Plant - Heber, California

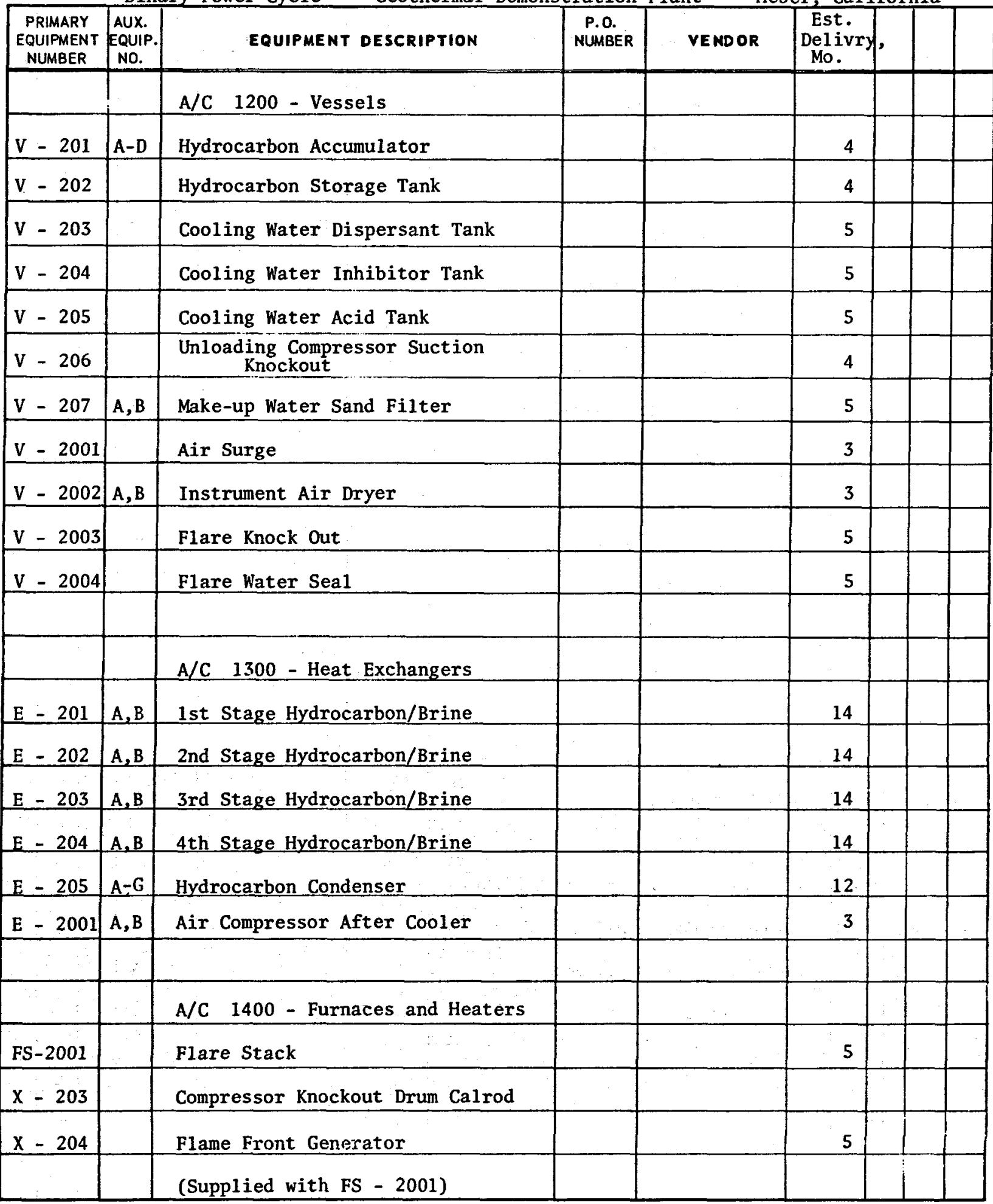




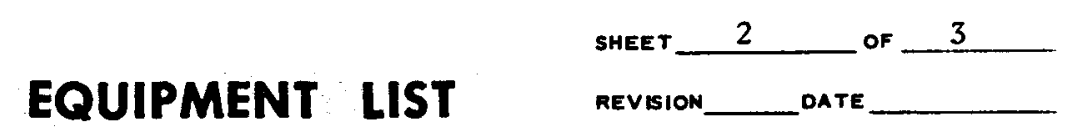

CONTRACT No. 7523

CUSTOMER Electric Power Research Institute

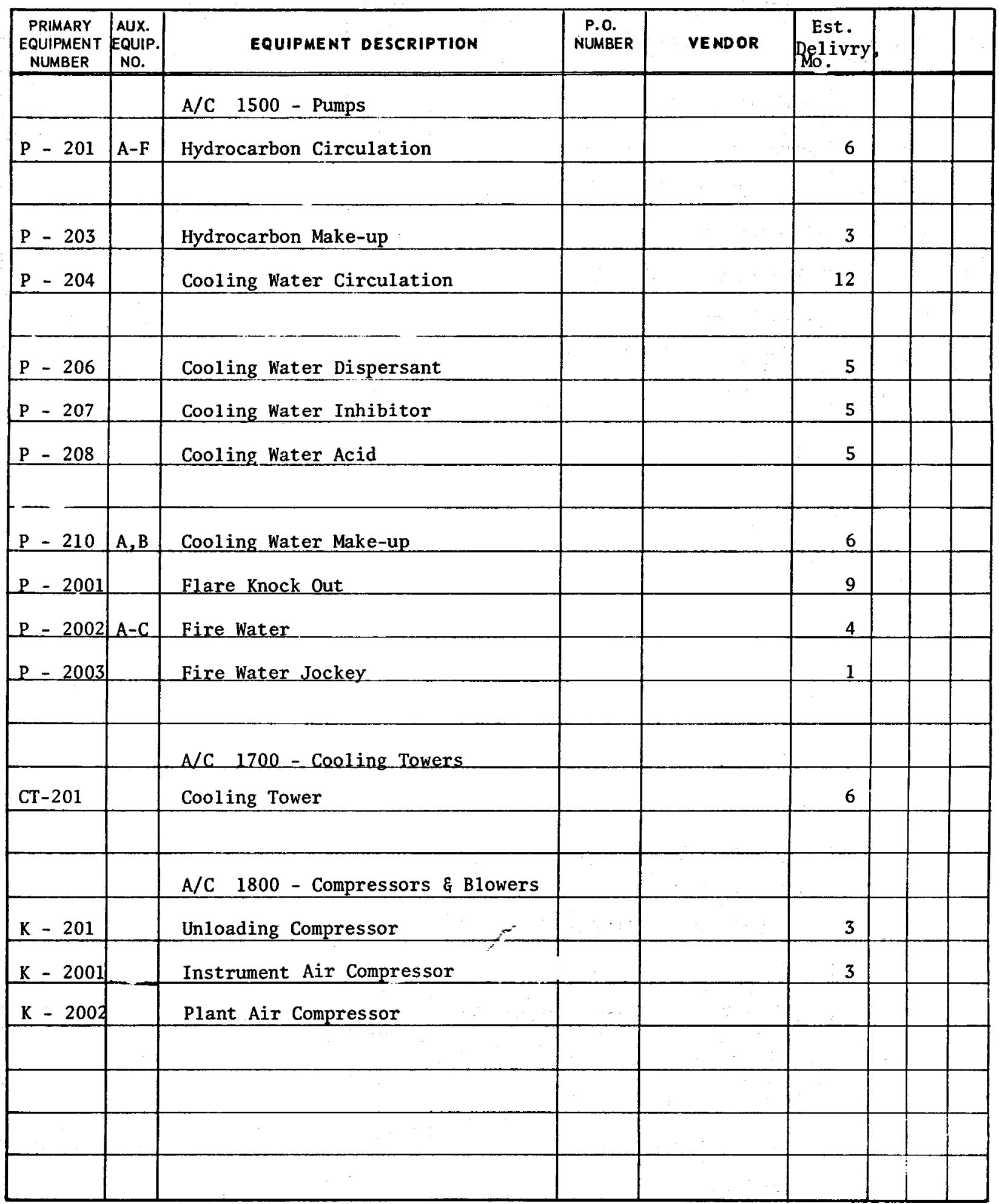


REVISION DATE

CONTRACT No.

7523

CUSTOMER Electric Power Research Institute

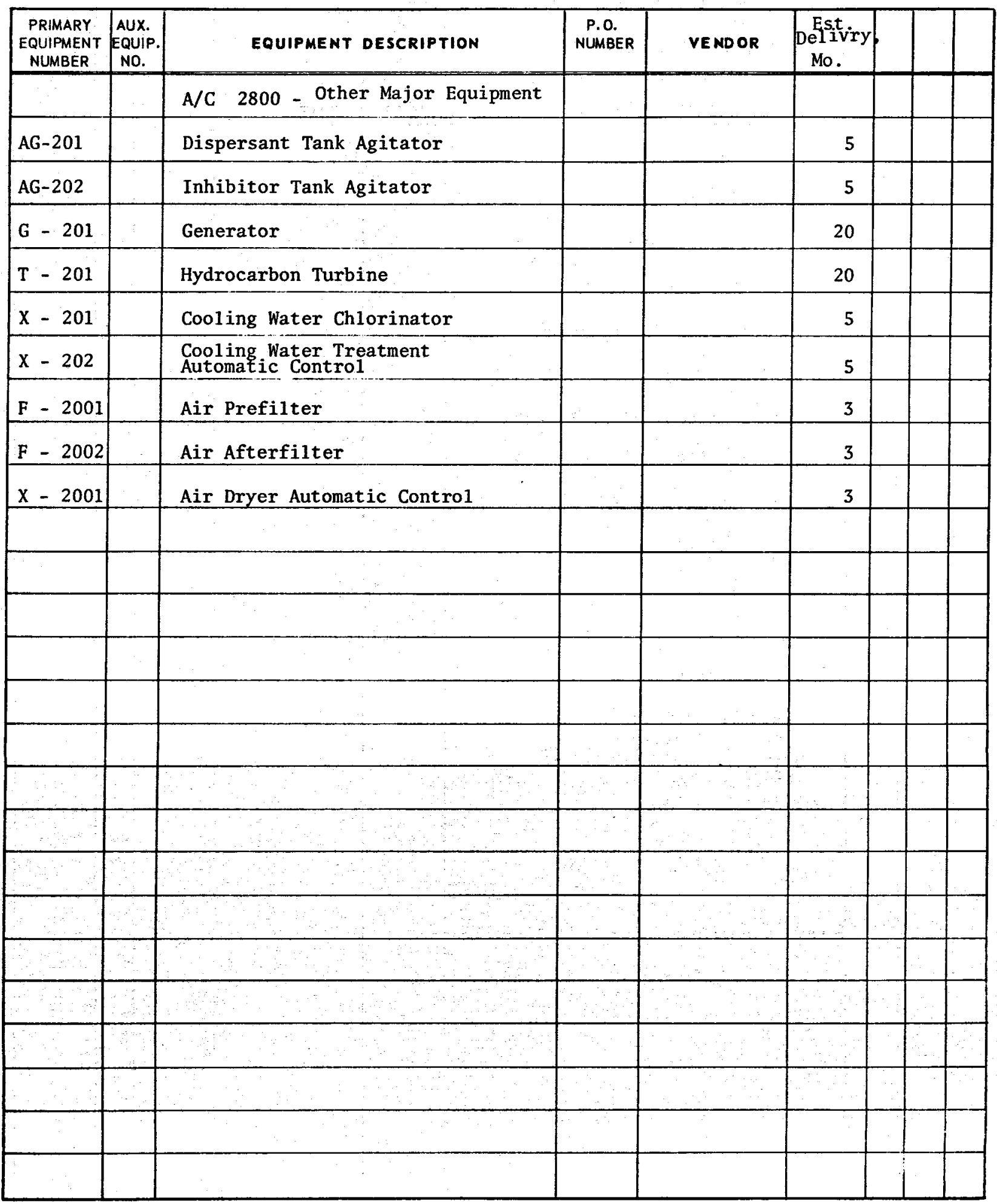




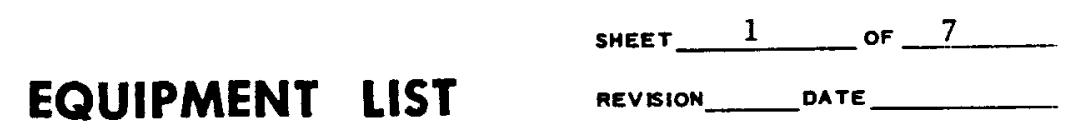

CONTRACT No.

7523

CUSTOMER _. Electric Power Research Institute

Instrument List - Field Mounted

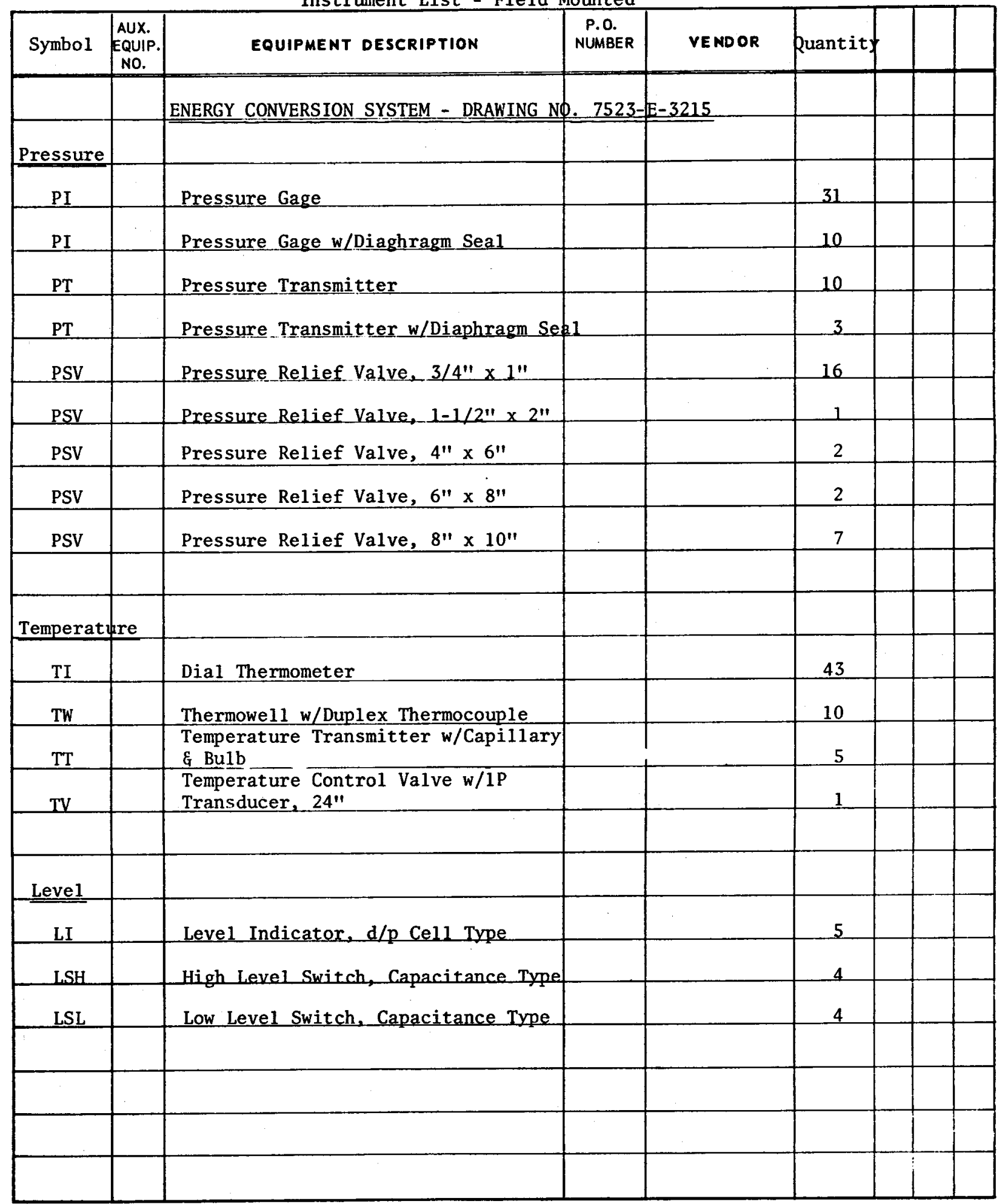


EQUIPMENT LIST

SHEET $\quad 2 \quad$ OF -7

CONTRACT No.

7523

CUSTOMER

Electric Power Research Institute

Instrument List - Field Mounted

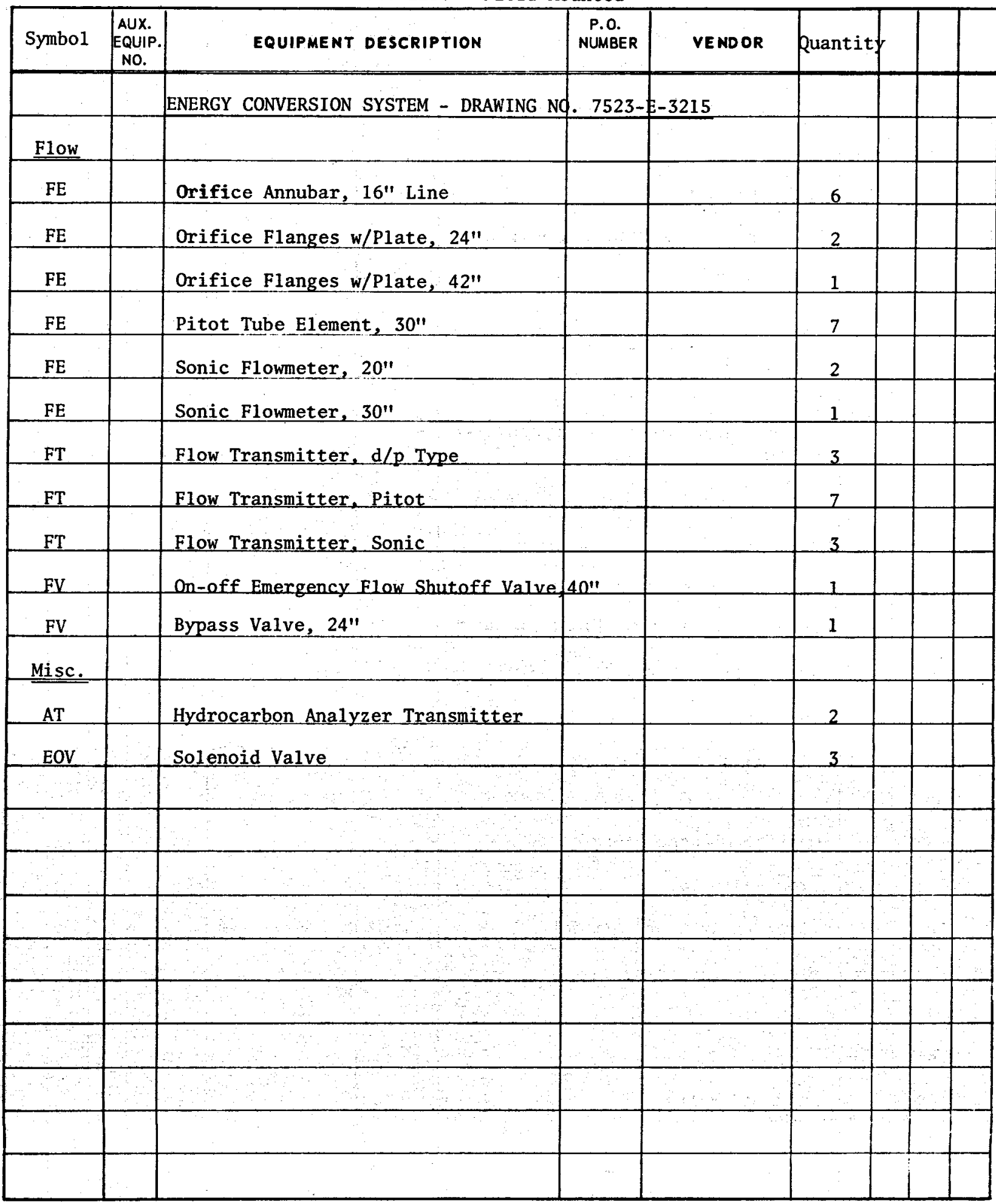




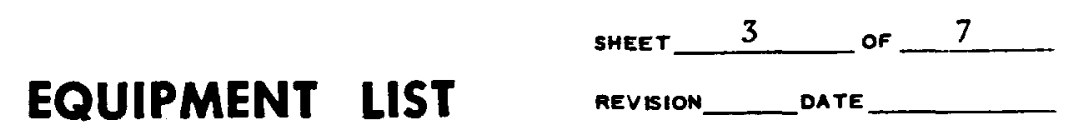

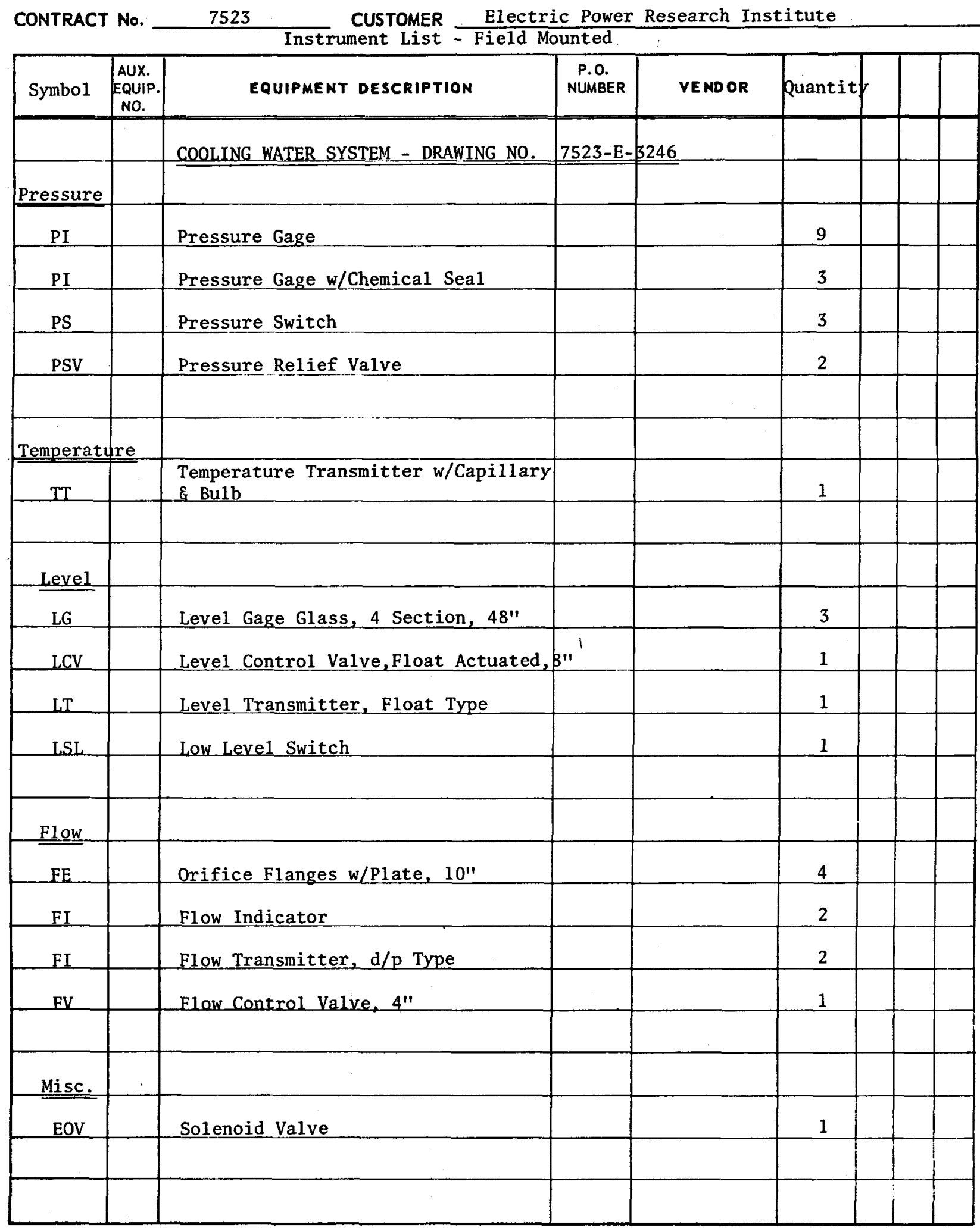




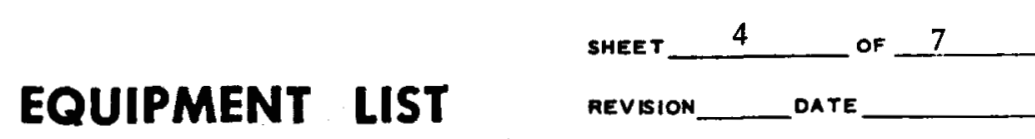

CONTRACT No. 7523 CUSTOMER Electric Power Research Institute

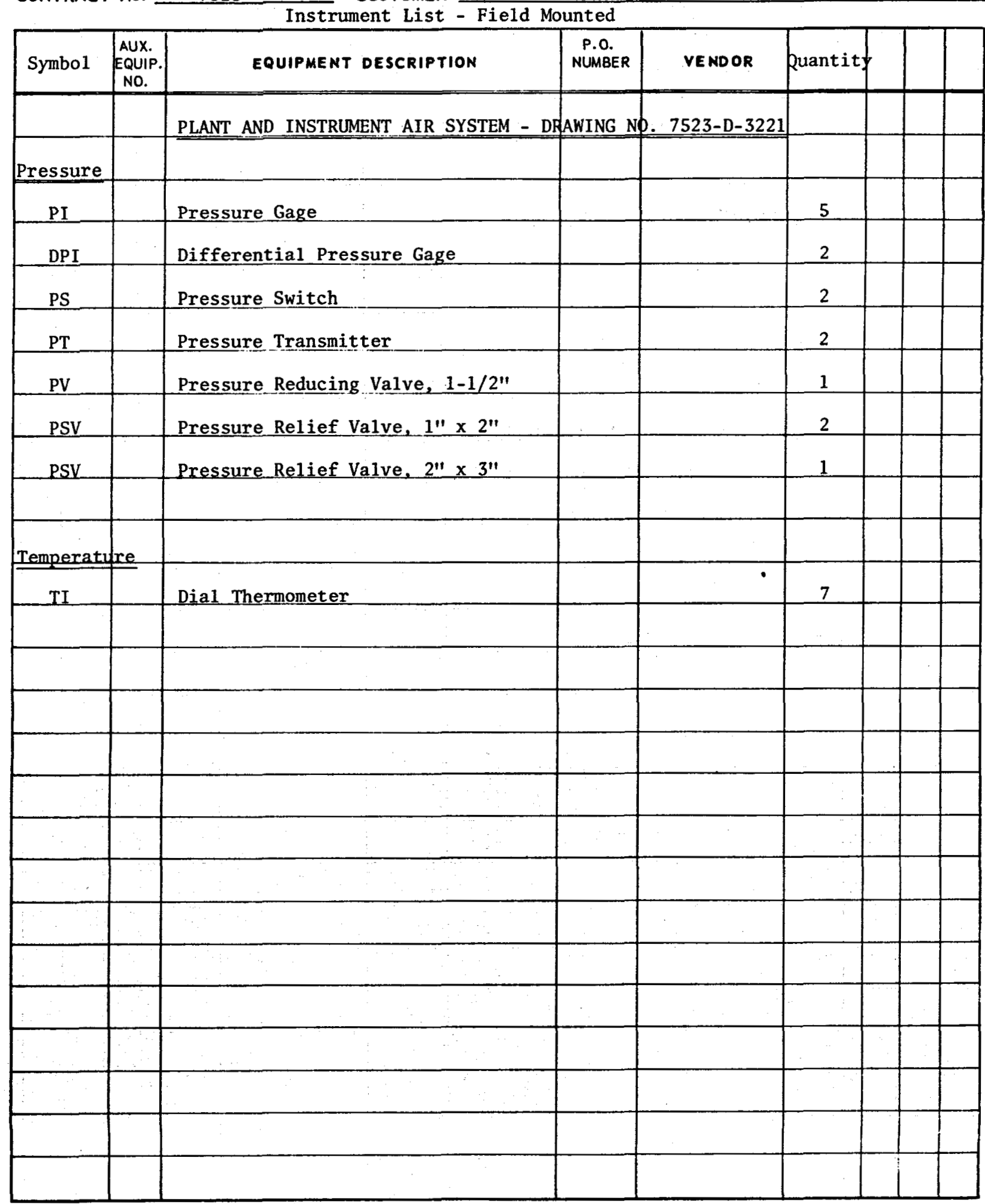




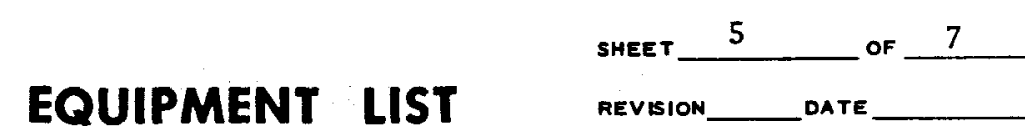

CONTRACT No.

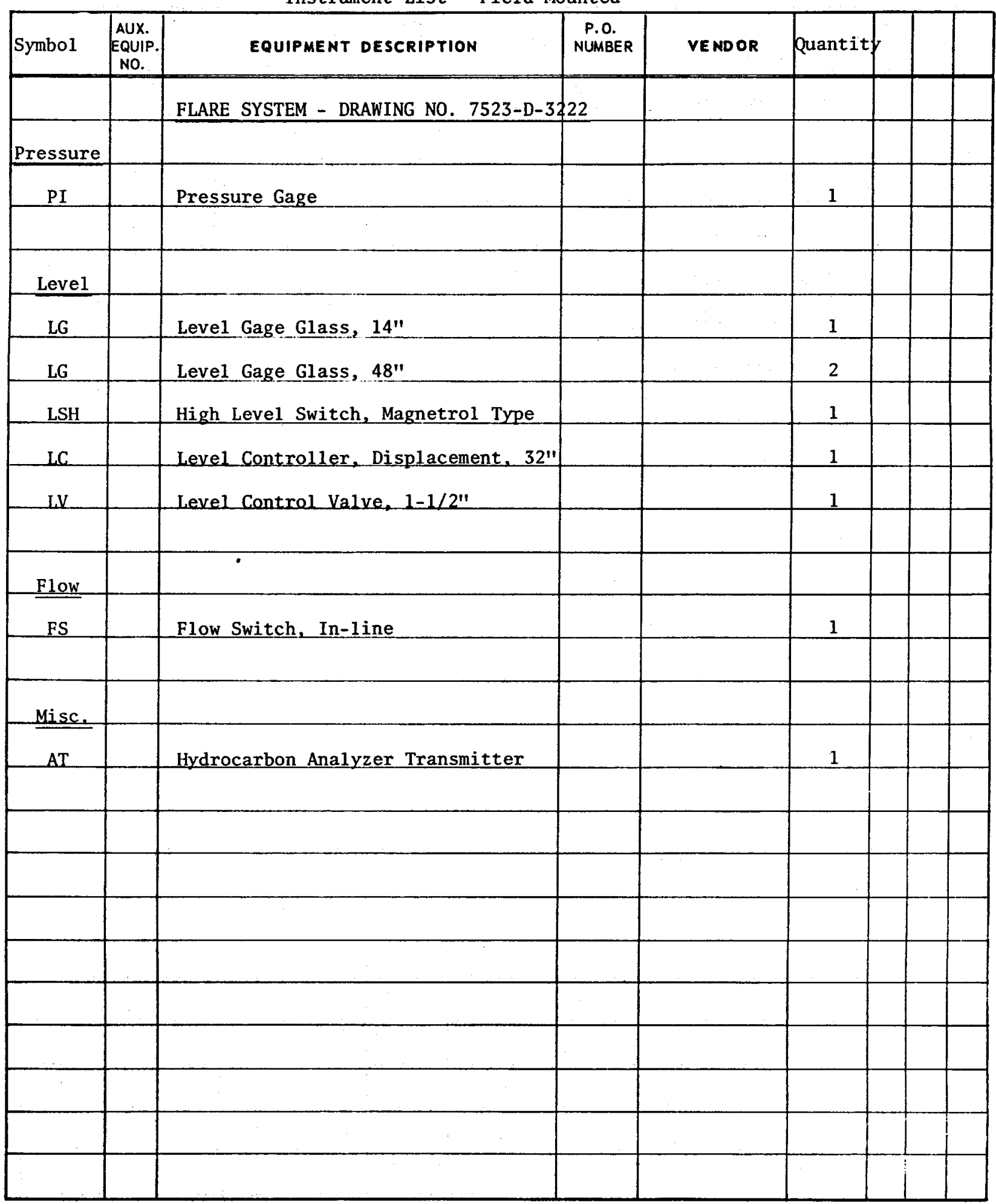




\section{EQUIPMENT LIST}

SHEET_ 6 OF 7

REVISION___ DATE

CONTRACT No.

7523

CUSTOMER Electric Power Research Institute

Instrument List - Panel Mounted

\begin{tabular}{|c|c|c|c|c|c|c|c|}
\hline Symbol & $\begin{array}{l}\text { AUX. } \\
\text { EQUIP. } \\
\text { NO. }\end{array}$ & EQUIPMENT DESCRIPTION & $\begin{array}{l}\text { P.O. } \\
\text { NUMBER }\end{array}$ & VENDOR & Quantit & & \\
\hline \multicolumn{8}{|c|}{ Indicators } \\
\hline PI & & Pressure Indicator & & & 2 & & \\
\hline $\mathrm{AI}$ & & Hydrocarbon Analyzer Indicator & & & 3 & & \\
\hline \multicolumn{8}{|l|}{ Recorders } \\
\hline $\mathrm{PR}$ & & Pressure Recorder & & & 13 & & \\
\hline TR & & Temperature Recorder & & & 7 & & \\
\hline TR & & Multipoint Temperature Recorder & & & $7 \mathrm{Po}$ & ints & \\
\hline FR & & Flow Recorder & & & 15 & & \\
\hline \multicolumn{8}{|c|}{$\begin{array}{l}\text { Recorder } \\
\text { Controllers } \\
\end{array}$} \\
\hline TRC & & Temperature Recorder Controller & & & 1 & & \\
\hline \multicolumn{8}{|c|}{\begin{tabular}{|l|l} 
Hand & \\
Control1 & rs \\
\end{tabular}} \\
\hline $\mathrm{HC}$ & & Generator Set Point & & & 1 & & \\
\hline $\mathrm{HC}$ & & Turbine System Shutdown & & & 1 & & \\
\hline \multicolumn{8}{|l|}{ Switches } \\
\hline PSL & & Low Pressure Switch & & & 1 & & \\
\hline PSH & & High Pressure Switch & & & 1 & & \\
\hline TSL & & Low Temperature Switch & & & 2 & & \\
\hline TSH & & High Temperature Switch & & & 1 & & \\
\hline sc & & $\begin{array}{l}\text { Turbine Overspeed Switch-Emergency } \\
\text { Shutdown System }\end{array}$ & & & 1 & & \\
\hline & & & & & & & \\
\hline & & ! & & & & & \\
\hline
\end{tabular}




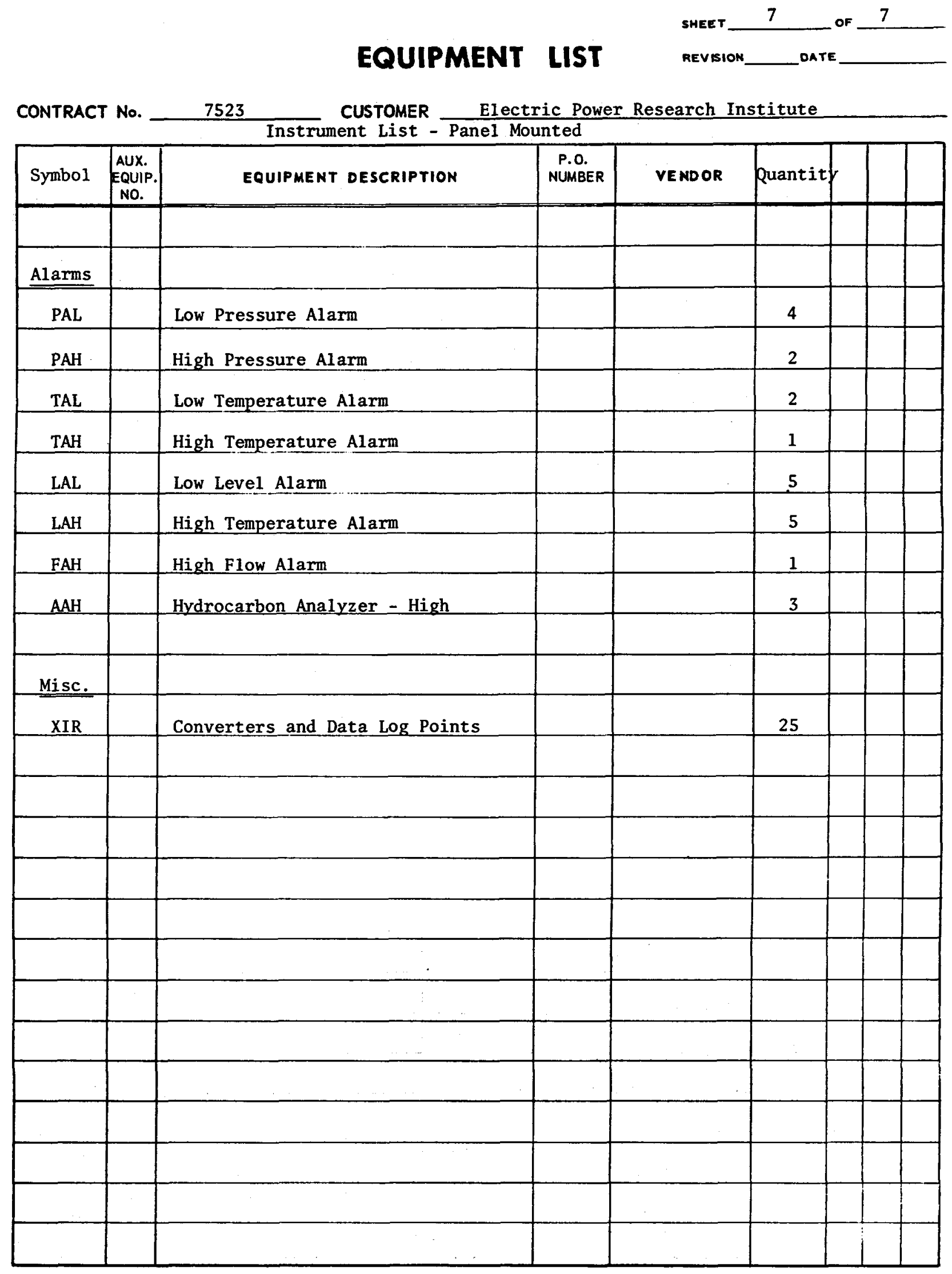




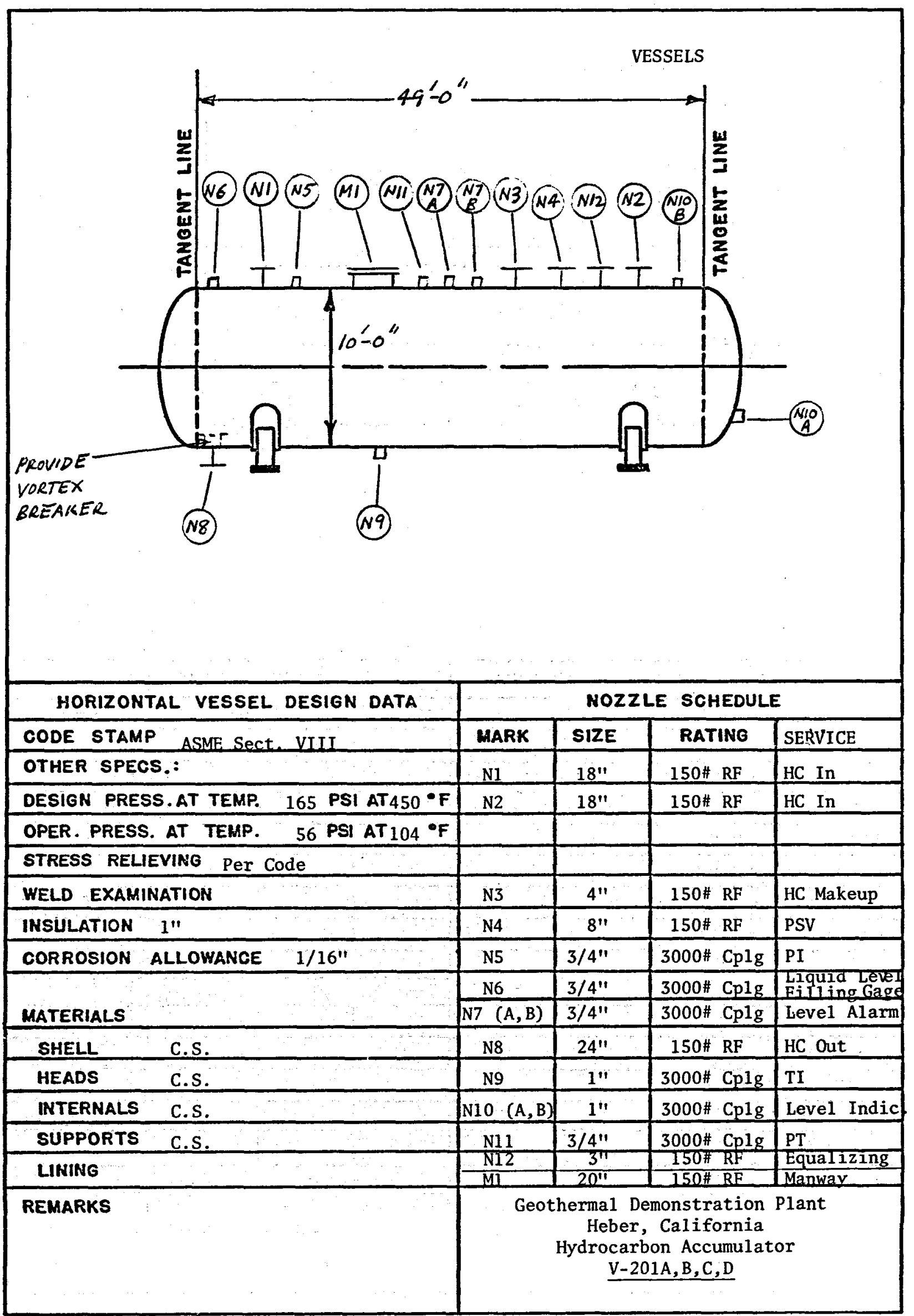




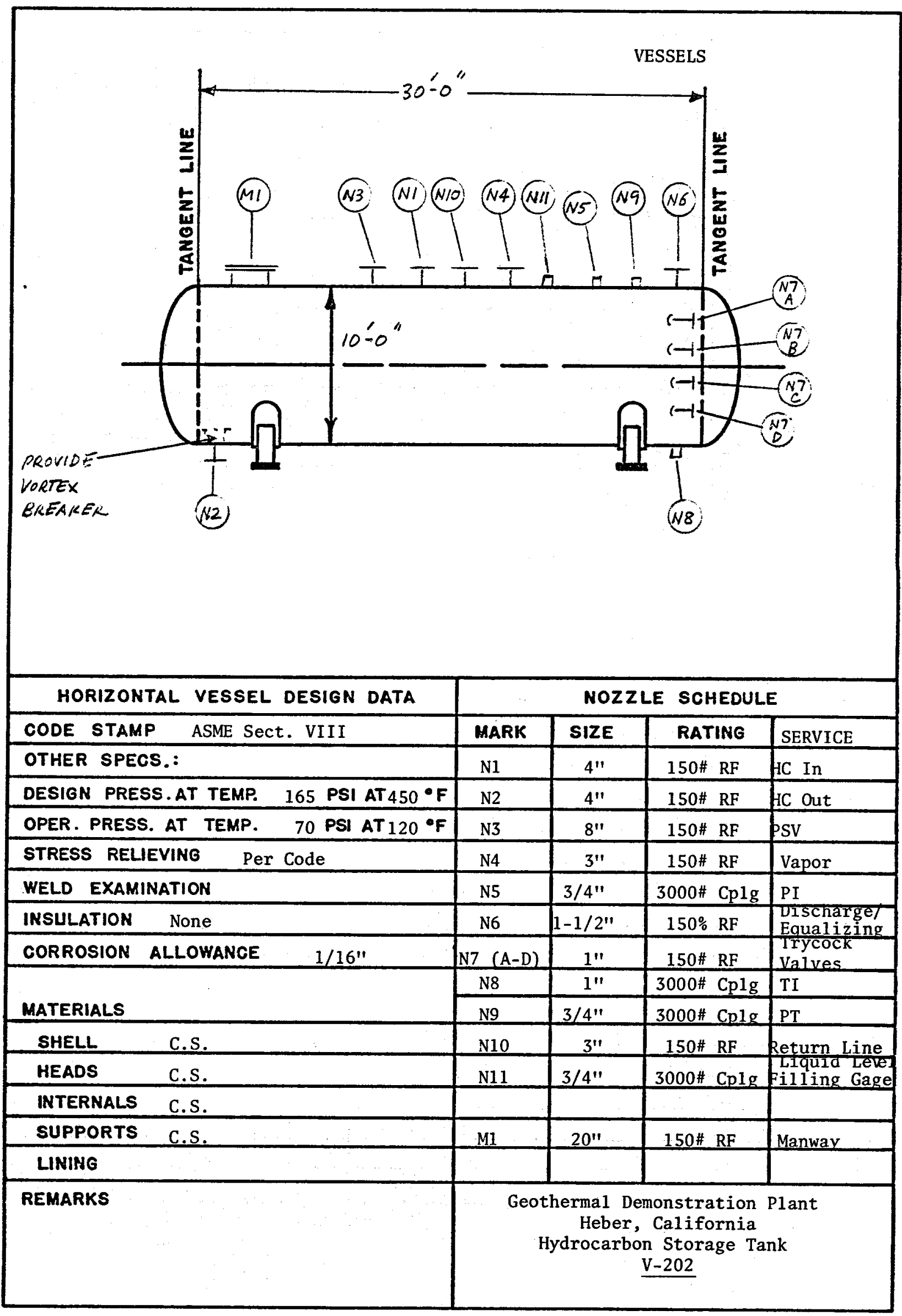


VESSELS

VERTICAL VESSEL DESIGN DATA

CODE STAMP ASME Section VIII

OTHER SPECS.:

DESIGN PRESS. AT TEMP. 165PSI AT $450^{\circ} \mathrm{F}$

OPER. PRESS. AT TEMP. 134 PSI AT 120 ० $\mathrm{F}$

STRESS RELIEVING Per Code

WELD EXAMINATION

INSULATION None

CORROSION ALLOWANCE 1/16"

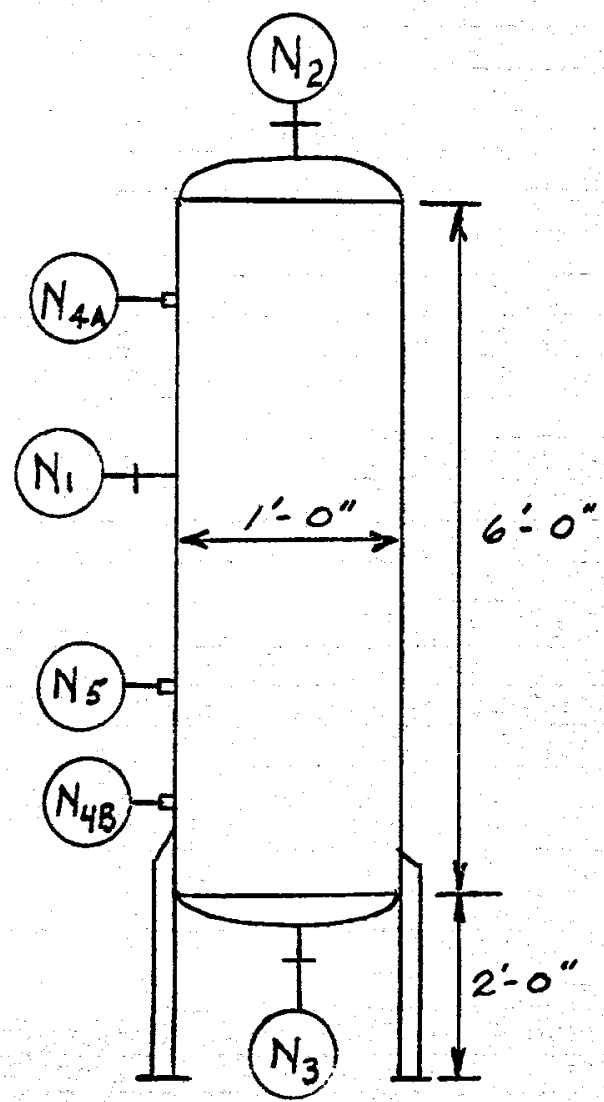

MATERIALS

SHELL C.S.

HEADS C.S.

INTERNALS

SUPPORTS C.S.

LINING

TRAYS

NOZZLE SCHEDULE

\begin{tabular}{|l|c|c|l|}
\hline MARK & SIZE & RATING & FACING \\
\hline N1 & $3^{\prime \prime}$ & 150\# RF & HC Vapor In1 \\
\hline N2 & $3^{\prime \prime}$ & $150 \#$ RF & HC Vapor In1 \\
\hline N3 & $1^{\prime \prime}$ & $150 \#$ RF & Drain \\
\hline N4 (A,B) & $1^{\prime \prime}$ & $3000 \#$ Cp1g & Leve1 Gage \\
\hline N5 & $11 / 4^{\prime \prime}$ & $3000 \#$ Cplg & Calrod \\
\hline & & & \\
\hline & & & \\
\hline & & & \\
\hline & & & \\
\hline & & & \\
\hline & & & \\
\hline & & & \\
\hline
\end{tabular}

REMARKS

Geotherma1 Demonstration P1ant

Heber, California

Compressor Suction Knockout Drum V-206 
HEAT EXCHANGER

\begin{tabular}{|c|c|c|}
\hline \multicolumn{2}{|c|}{ CUSTOMER Electric Power Research Institute } & $\begin{array}{l}\text { JOB NO. } \frac{7523}{1} \\
\text { ITEM NO. E-201A, B - E-204A, B }\end{array}$ \\
\hline \multicolumn{2}{|c|}{ PLANT $\quad$ Geothermal Demonstration Plant } & DATE $7 / 17 / 76$ \\
\hline \multicolumn{2}{|l|}{ Heber, California } & QUOTE NO. \\
\hline \multicolumn{2}{|l|}{ SERVICE } & REFERENCE \\
\hline \multicolumn{3}{|c|}{ SIZE 60" dia. $x$ 59' (est. OVeräPPE CEN CONNECTED IN SERIES/PARALLEL } \\
\hline \multicolumn{2}{|c|}{$\begin{array}{lll}\text { SURFACE PER SHELL } & \text { NO. OF SHELLS } & 8 \\
\end{array}$} & TOTAL SURFACE $180,000 \mathrm{ft}^{2}(\mathrm{es}$ \\
\hline \multicolumn{3}{|c|}{ PERFORMANCE } \\
\hline \multirow[b]{2}{*}{ FLUID CIRCULATED } & SHELL SIDE & TUBE SIDE \\
\hline & \multirow{2}{*}{$\begin{array}{l}80 \% \text { I sobutane }-20 \% \text { Isopentan } \\
7.687\left(10^{6}\right) 1 \mathrm{~b} / \mathrm{hr}\end{array}$} & Brine $(14,600$ PPM Tota \\
\hline TOTAL FLUID ENTERING & & Dissolved Solid \\
\hline \multicolumn{3}{|l|}{ VAPOR } \\
\hline LIQUID & $7.687\left(10^{6}\right) 1 \mathrm{~b} / \mathrm{hr}$ & $6.722\left(10^{6}\right) 1 \mathrm{~b} / \mathrm{hr}$ \\
\hline \multicolumn{3}{|l|}{ STEAM } \\
\hline \multicolumn{3}{|l|}{ NON-CONDENSABLES } \\
\hline FLUID VAPORIZED OR CONDENSED & $7.687\left(10^{6}\right) \mathrm{lb} / \mathrm{hr}$ & \\
\hline \multicolumn{3}{|l|}{ STEAM CONDENSED } \\
\hline GRAVITY-LIQUID QTEMR & $109{ }^{\circ} \mathrm{F}$ & @ 360 of \\
\hline VISCOSITY-LIOUID QTEMP. & $109 \quad{ }^{\circ} \mathrm{F}$ & $3600^{\circ} \mathrm{F}$ \\
\hline MOLECULAR WEIGHT-VAPORS & 61 & \\
\hline SPECIFIC HEAT-LIQUIDS See ent & thalpy curves & B.T.U./LB ${ }^{\circ} \mathrm{F}$ \\
\hline LATENT HEAT-VAPORS & in supercrit region & B.T.U./LB \\
\hline TEMPERATURE IN & ${ }^{\circ} \mathrm{F}(2$ & 360 \\
\hline TEMPERATURE OUT & 295 & 153 \\
\hline OPERATING PRESSURE & 535 (inlet) & PSIG \\
\hline NUMEER OF PASSES PER SHELL & 1 & 1 \\
\hline VELOCITY & FT./SEC. & (a11ow $15 \max$.$) FT. / SEC.$ \\
\hline PRESSURE DROP (ALLOW/CALC.) & PSI & PSI \\
\hline FOULING FACTOR (MIN.) & 0 & Inlet temp. to $271^{\circ} \mathrm{F}-.0001$ \\
\hline F.F. (tube side) $270^{\circ} \mathrm{F}$ to $217^{\circ} \mathrm{F}$ & $\mathrm{F}-.0011 ; 216^{\circ} \mathrm{F}$ to $177^{\circ} \mathrm{F}-.0011 ;$ & $176^{\circ} \mathrm{F}$ to $153^{\circ} \mathrm{F}-.0033$ \\
\hline HEAT EXCHANGED - B.T.U/HR. & $1,420.8\left(10^{6}\right)$ & rrected) \\
\hline TRANSFER RATE - SERVICE & CLEAN & \\
\hline & CONSTRUCTION & \\
\hline DESIGN PRESSURE & PSIG & PSIG \\
\hline TEST PRESSURE & 1,005 & PSIG \\
\hline DESIGN TEMPERATURE & 360 & 360 \\
\hline TUEES- C.S. & LENGTH & PITCH \\
\hline SHELL & THICKNESS & \\
\hline SHELL COVER & FLOATING & HEAD COVER \\
\hline CHANNEL & CHANNEL & COVER \\
\hline TUBE SHEET - STATIONARY & FLOATING & \\
\hline BAFFLES - CROSS & THICKNESS & SPACING \\
\hline BAFFLE - LONG & THICKNES & \\
\hline TUBE SUPPORTS & THICKNES & \\
\hline GASKETS & & \\
\hline CONNECTIONS - SHELL-IN & SERIES & $300 \quad 1 b \quad R F$ \\
\hline CHANNEL - IN & SERIES & $150 \mathrm{Ib}$ RF \\
\hline CORROSION ALLOWANCE - SHELL & TUBE SIDE & E $1 / 16^{\prime \prime}$ \\
\hline CODE REQUIREMENTS & TEMA CL & C (1) \\
\hline WEIGHTS - EACH SHELL & FULL OF & WATER \\
\hline REMARKS: (1) W/o cross baffle & es (2) see attached enthal & Ipy diagram \\
\hline
\end{tabular}




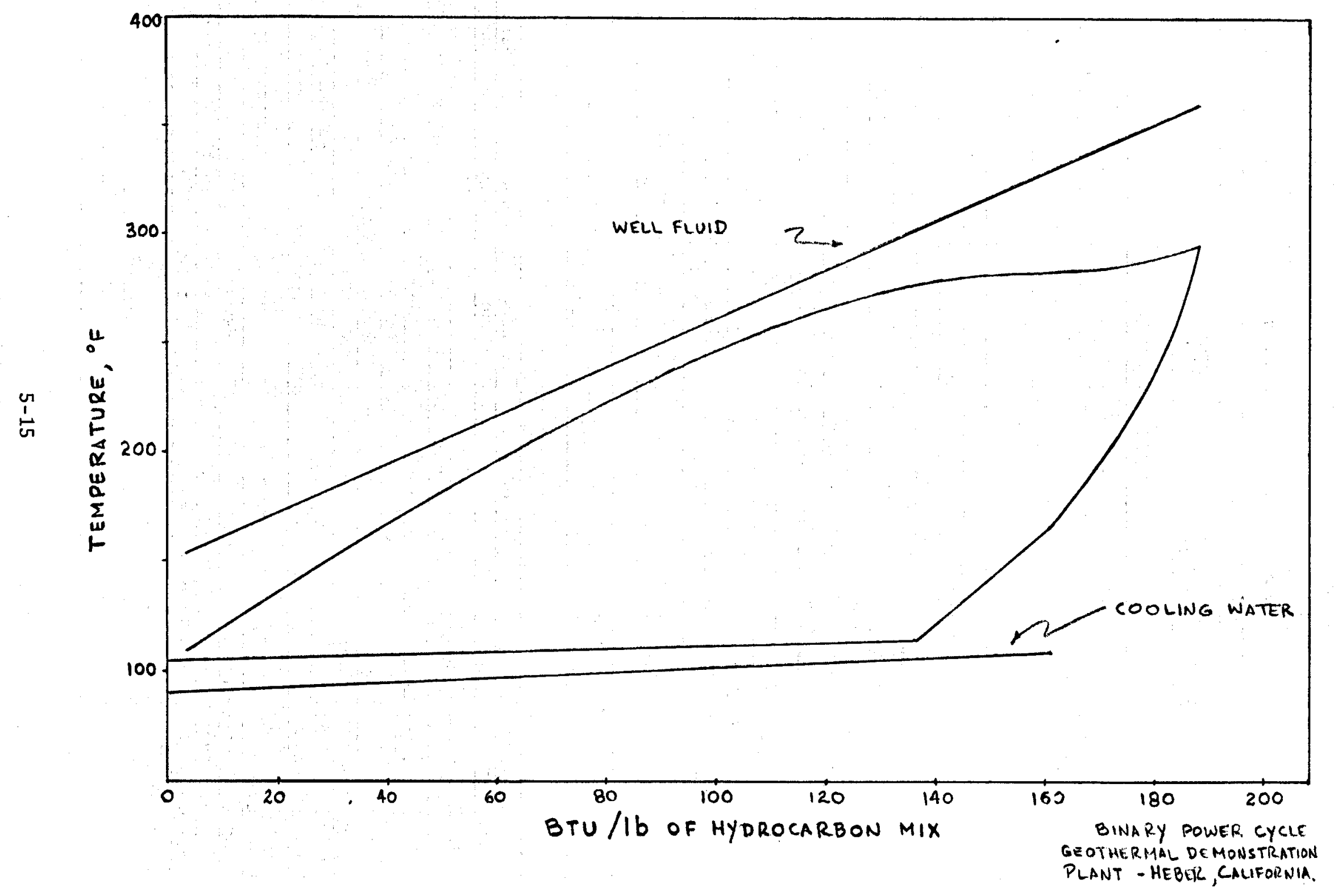




\section{HEAT EXCHANGER}

\begin{tabular}{|c|c|c|}
\hline CUSTOMER Electric Power Rese & & $\begin{array}{ll}\text { JOB NO. } & 7523 \\
\text { ITEM NO. } & \text { E-205A-G }\end{array}$ \\
\hline \multicolumn{2}{|c|}{ PLANT Geothermal Demonstration Plant } & DATE $7 / 17 / 76$ \\
\hline \multicolumn{2}{|c|}{ Heber, California } & QUOTE NO \\
\hline \multicolumn{2}{|c|}{ Hydrocarbon Condenser } & REFERENCE \\
\hline \multicolumn{2}{|c|}{ SIZE $81^{\prime \prime}$ dia. $\times$ 52' (est. overaftpe CJN } & RIES/PARALLEL $1 / 7$ \\
\hline \multicolumn{3}{|c|}{ SURFACE PER SHELL $157,286 \mathrm{ft}^{2}$ NO. OF SHELLS } \\
\hline \multicolumn{3}{|c|}{ PERFORMANCE } \\
\hline & SHELL SIDE & \\
\hline FLUID CIRCULATED & $80 \%$ Isobutane $-20 \%$ Isopentan & $\frac{\text { TUBE SIDE }}{\text { Cooling Water }}$ \\
\hline TOTAL FLUIDENTERING & $\frac{80 \% \text { 1 sobutane }-20 \% \text { 1sopentan }}{7.687\left(10^{6}\right) \mathrm{lb} / \mathrm{hr}}$ & $67.783\left(10^{6}\right) 1 \mathrm{~b} / \mathrm{hr}$ \\
\hline VAPOR & $7.687\left(10^{6}\right) 1 \mathrm{~b} / \mathrm{hr}$ & \\
\hline \multicolumn{3}{|l|}{ LIQUID } \\
\hline \multicolumn{3}{|l|}{ STEAM } \\
\hline \multicolumn{3}{|l|}{ NON-CONDENSABLES } \\
\hline FLUID VAPORIZED OR CONDENSED & $7.687\left(10^{6}\right) 1 \mathrm{~b} / \mathrm{hr}$ & \\
\hline \multicolumn{3}{|l|}{ STEAM CONDENSED } \\
\hline GRAVITY-LIQUID QTEMP & $0.544 \quad Q$ & $90 \quad{ }^{\circ} \mathrm{F}$ \\
\hline VISCOSITY-LIOUID ETEMP. & $0.148 \quad$ c.S.e & $90 \quad{ }^{\circ} \mathrm{F}$ \\
\hline MOLECULAR WEIGHT-VAPORS & 61 & \\
\hline SPECIFIC HEAT-LIOUIDS & hthalpy curves & B.T.U./LB ${ }^{\circ} \mathrm{F}$ \\
\hline LATENT HEAT-VAPORS Desuperh & leating \& condensing B.T.U./LB & B.T.U./LB \\
\hline TEMPERATURE IN & $166 \quad{ }^{\circ} \mathrm{F}$ & ${ }^{\circ} \mathbf{F}$ \\
\hline TEMPERATURE OUT & 104 & 108 \\
\hline OPERATING PRESSURE & PSIG & PS1G \\
\hline NUMBER OF PASSES PER SHELL & 1 & 1 \\
\hline VELOCITY & FT./SEC. & FT./SEC. \\
\hline PRESSURE DROP (ALLOW/CALC.) & PSI & PSI \\
\hline FOULING FACTOR (MIN.) & 0 & .001 \\
\hline HEAT EXCHANGED - B.T.U/HR. & M.T.D. (Cori & rrected) \\
\hline TRANSFER RATE - SERVICE & CLEAN & \\
\hline & CONSTRUCTION & \\
\hline DESIGN PRESSURE & PSIG & PSIG \\
\hline TEST PRESSURE & PSIG & PSIG \\
\hline DESIGN TEMPERATURE & 450 & 450 \\
\hline TUBES- C.S. & LENGTH & PITCH \\
\hline SHELL & THICKNESS & \\
\hline SHELL COVER & FLOATING & HEAD COVER \\
\hline CHANNEL & CHANNEL & COVER \\
\hline TUBE SHEET - STATIONARY & FLOATING & \\
\hline BAFFLES - CROSS & THICKNESS & SPACING \\
\hline BAFFLE - LONG & THICKNESS & \\
\hline TUBE SUPPORTS & THICKNESS & \\
\hline GASKETS & & \\
\hline CONNECTIONS - SHELL - IN & SERIES & $1501 \mathrm{~b}$ RF \\
\hline CHANNEL - IN & SERIES & $150 \mathrm{lb} \mathrm{RF}$ \\
\hline CORROSION ALLOWANCE - SHELL & TUBE SIOE & $1 / 16^{\prime \prime}$ \\
\hline CODE REQUIREMENTS & TEMA CLA & $\mathrm{C}(1)$ \\
\hline WEIGHTS - EACH SHELL & FULL OF $N$ & WATER \\
\hline REMARKS: (1) W/o cross baf & Eles & \\
\hline
\end{tabular}




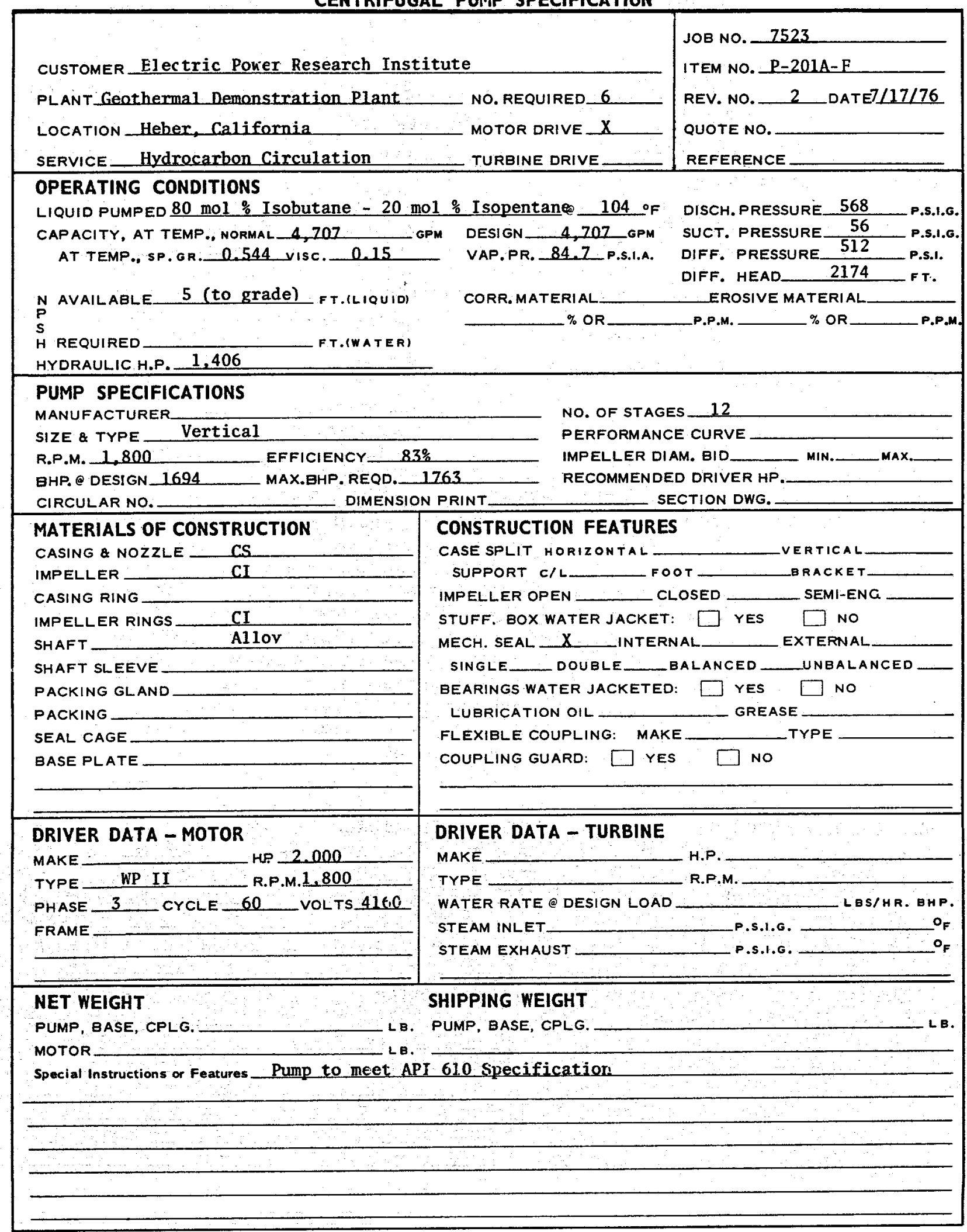


CENTRIFUGAL PUMP SPECIFICATION

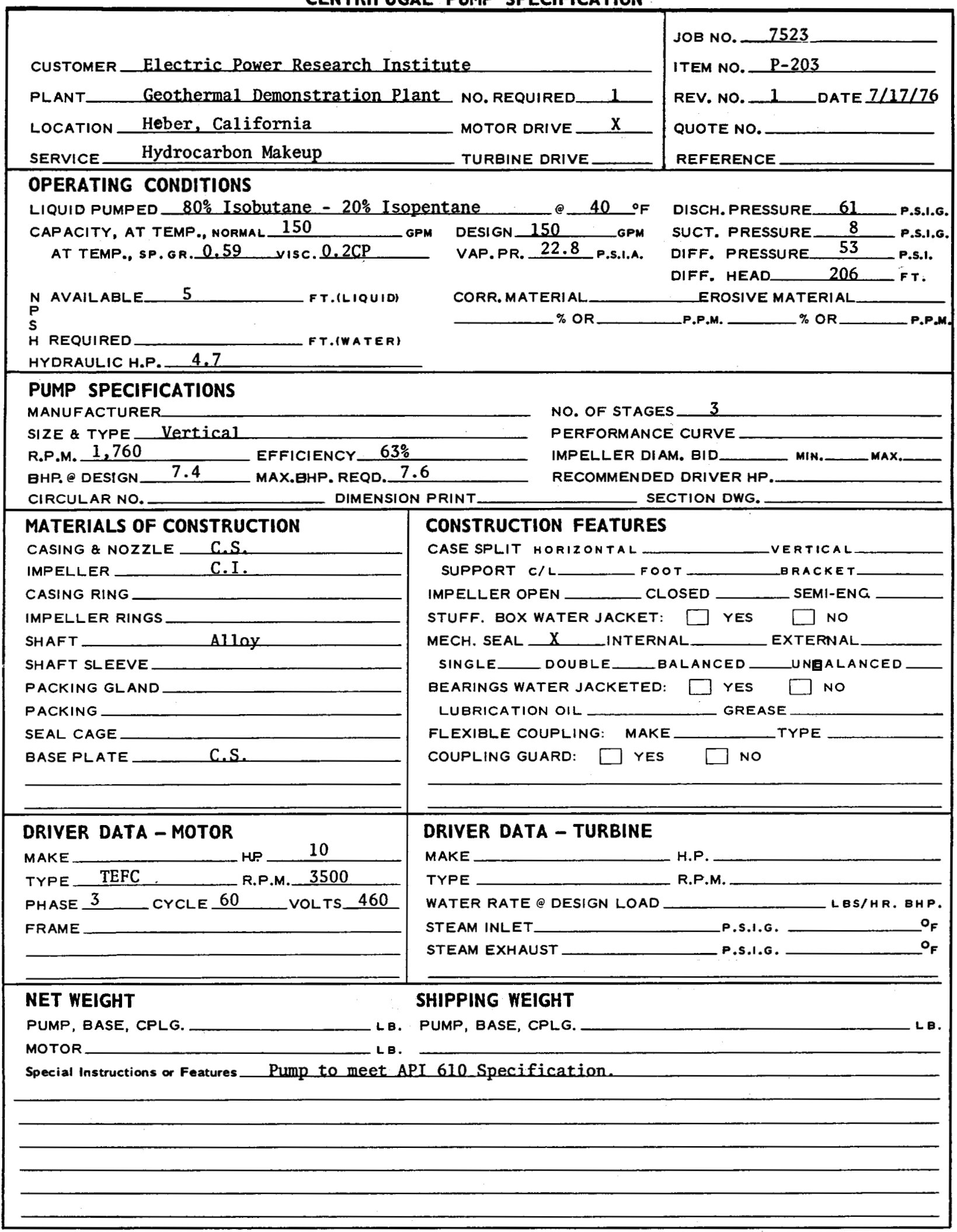


CUSTOMER Electric Power Research Institute

PLANT Geothermal Demonstration Plant LOCATION Heber. California SERVICE Cooling Water Circulation OPERATING CONDITIONS

LIQUID PUMPED Cooling Water

CAPACITY, AT TEMP.. NORMAL 68,543 AT TEMP SP GR 1.0 VISC 0.74

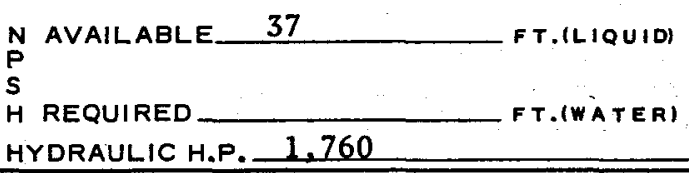

MATERIALS OF CONSTRUCTION

CASING \& NOZZLE C.I.

IMPELLER

CASING RING___ Bronze

IMPELLER RINGS__Bronze

SHAFT Alloy Steel

SHAFT SLEEVE___ Bronze

PACKING GLAND__ Bronze

PACKING

SEAL CAGE

BASE PLATE

\section{DRIVER DATA - MOTOR}

MAKE _ HP 2000

TYPE WPII R.P.M. 585

PHASE 3 CYCLE 60 VOLTS 4160

FRAME

\section{NET WEIGHT}

PUMP, BASE, CPLG.

MOTOR

Special Instructions or Features (B.

NO. OF STAGES _ 1

PERFORMANCE CURVE

IMPELLER DIAM. BID

RECOMMENDED DRIVER HP

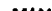
SECTION DWG.

\section{CONSTRUCTION FEATURES}

CASE SPLIT HORIZONTAL SUPPORT $C / L$

FOOT CLOSED

IMPELLER OPEN

STUFF. BOX WATER JACKET: $\square$ YES MECH. SEAL $\mathrm{X}$ INTERNAL

SINGLE_ DOUBLE_ _ BALANCED UNBALANCED

VERTICAL SEMI-ENG BEARINGS WATER JACKETED: $\square$ YES $\square$ NO LUBRICATION OIL $\mathrm{X}$ GREASE

FLEXIBLE COUPLING: MAKE __ TYPE COUPLING GUARD: $\square$ YES $\square$ NO

\section{DRIVER DATA - TURBINE}

MAKE

TYPE H.P.

WATER RATE@DESIGN LOAD R.P.M.

STEAM INLET P.S.I.G. LBS/HR. BHP. $O_{F}$ STEAM EXHAUST P.S.I.G.

SHIPPING WEIGHT

L. PUMP, BASE, CPLG L Pump to meet API 610 specification 
RECIPROCATING PUMP SPECIFICATION

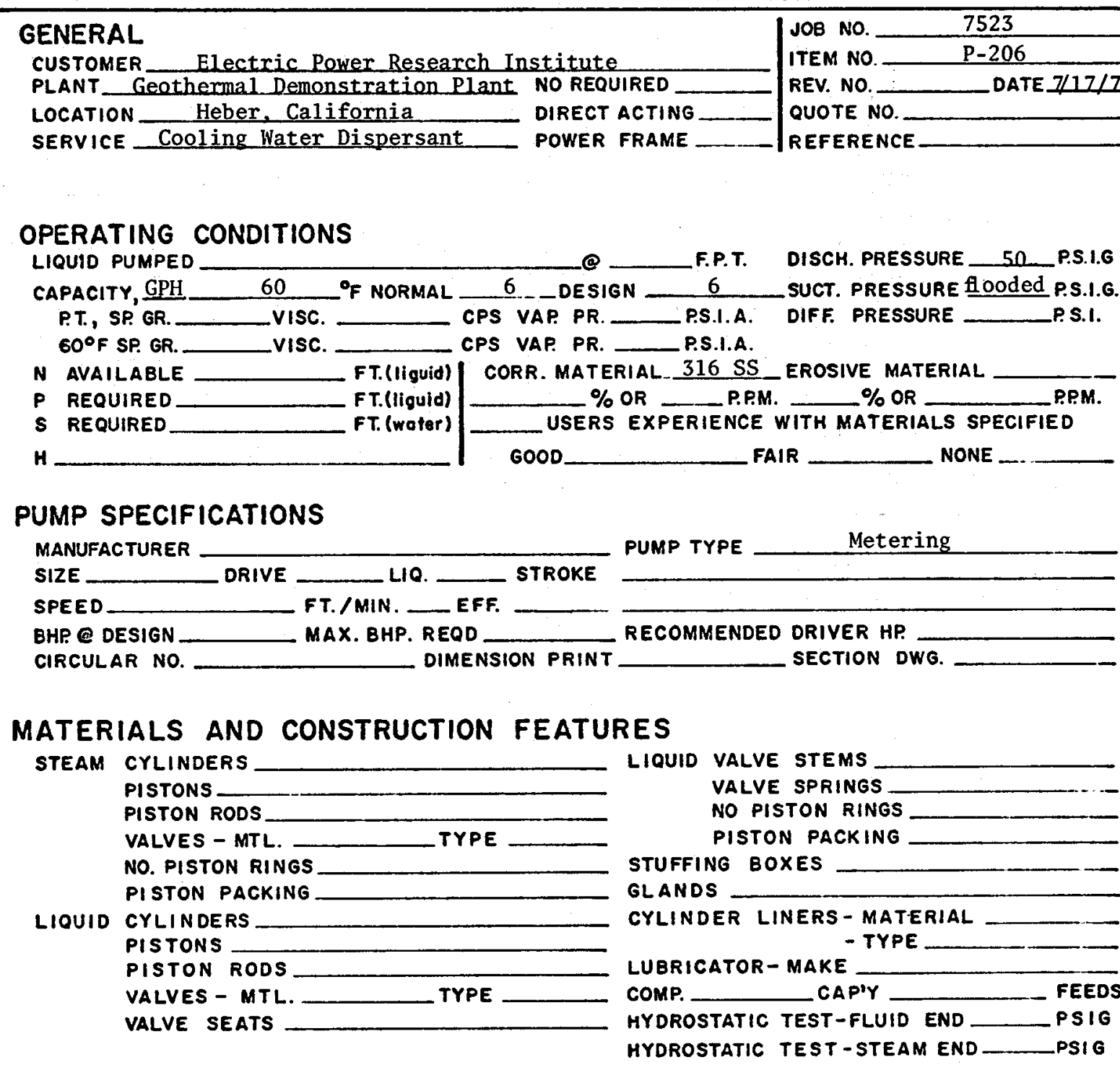

DRIVER DATA - MOTOR (Pwr.Frome) SSTEAM DATA - (Direct Acting)

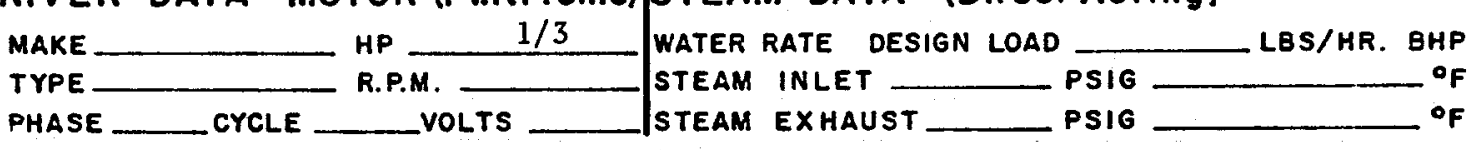

\section{STUFFING BOX DIMENSIONS}

STUFFING BOX LENGTH

DIAMETER RODS

SIZE OF PACKING

NET WEIGHT

PUMP, BASE

MOTOR

Special Instructlons or Features

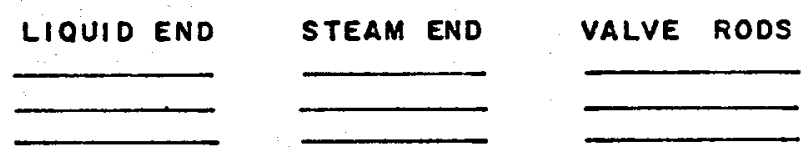

SHIPPING WEIGHT

LB PUMP, BASE LB 


\section{RECIPROCATING PUMP SPECIFICATION}

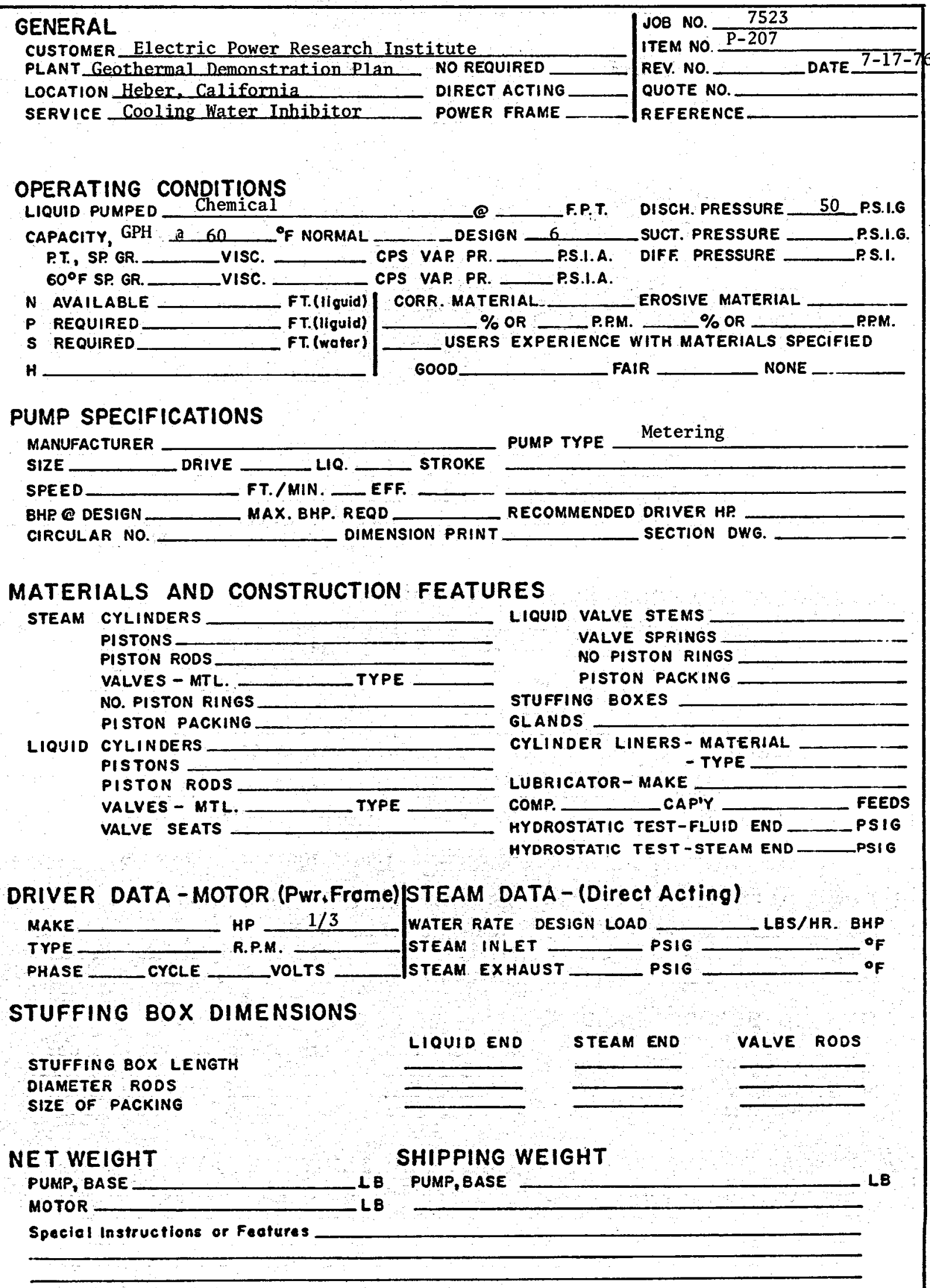




\section{RECIPROCATING PUMP SPÉCIFICATION}

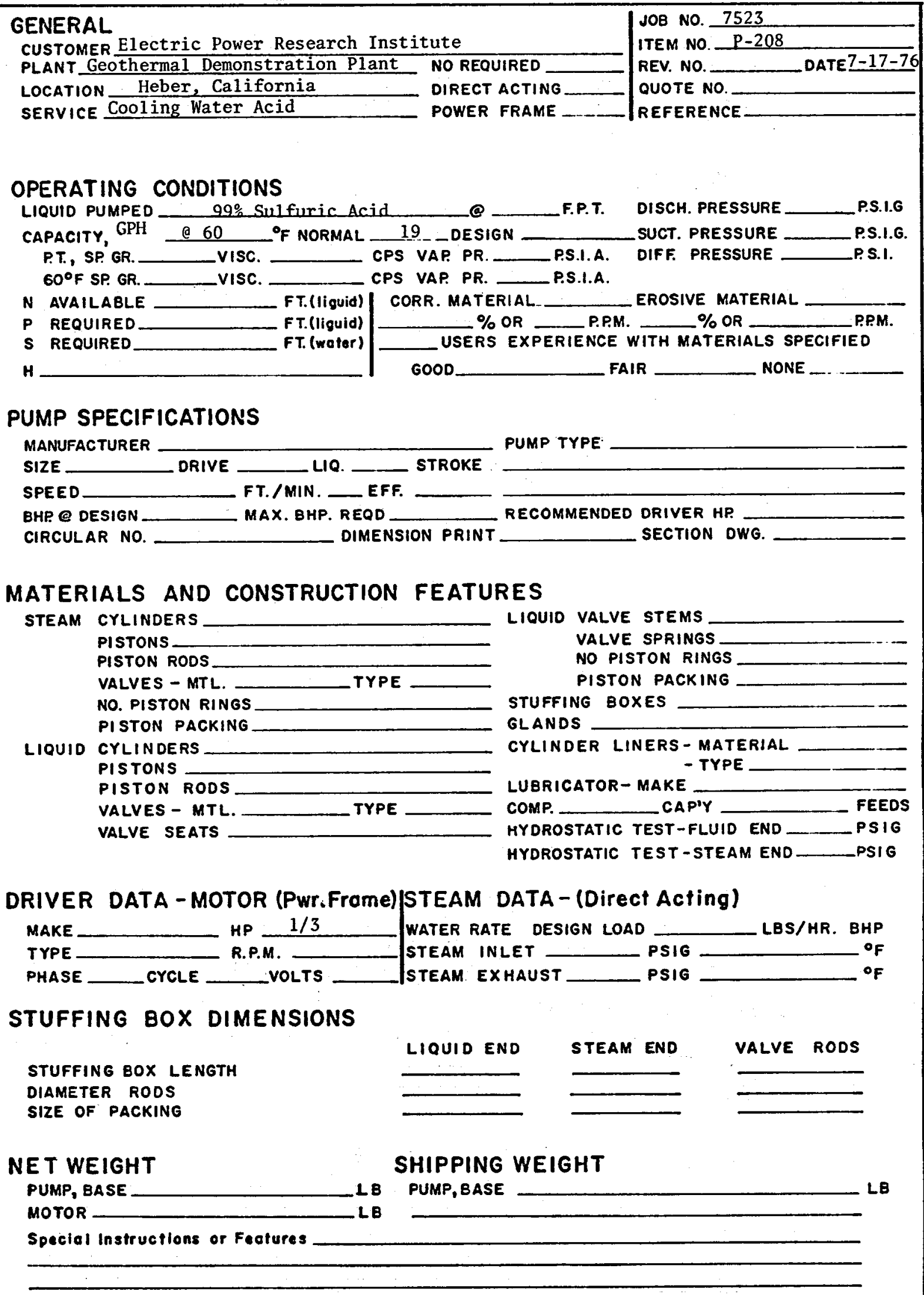




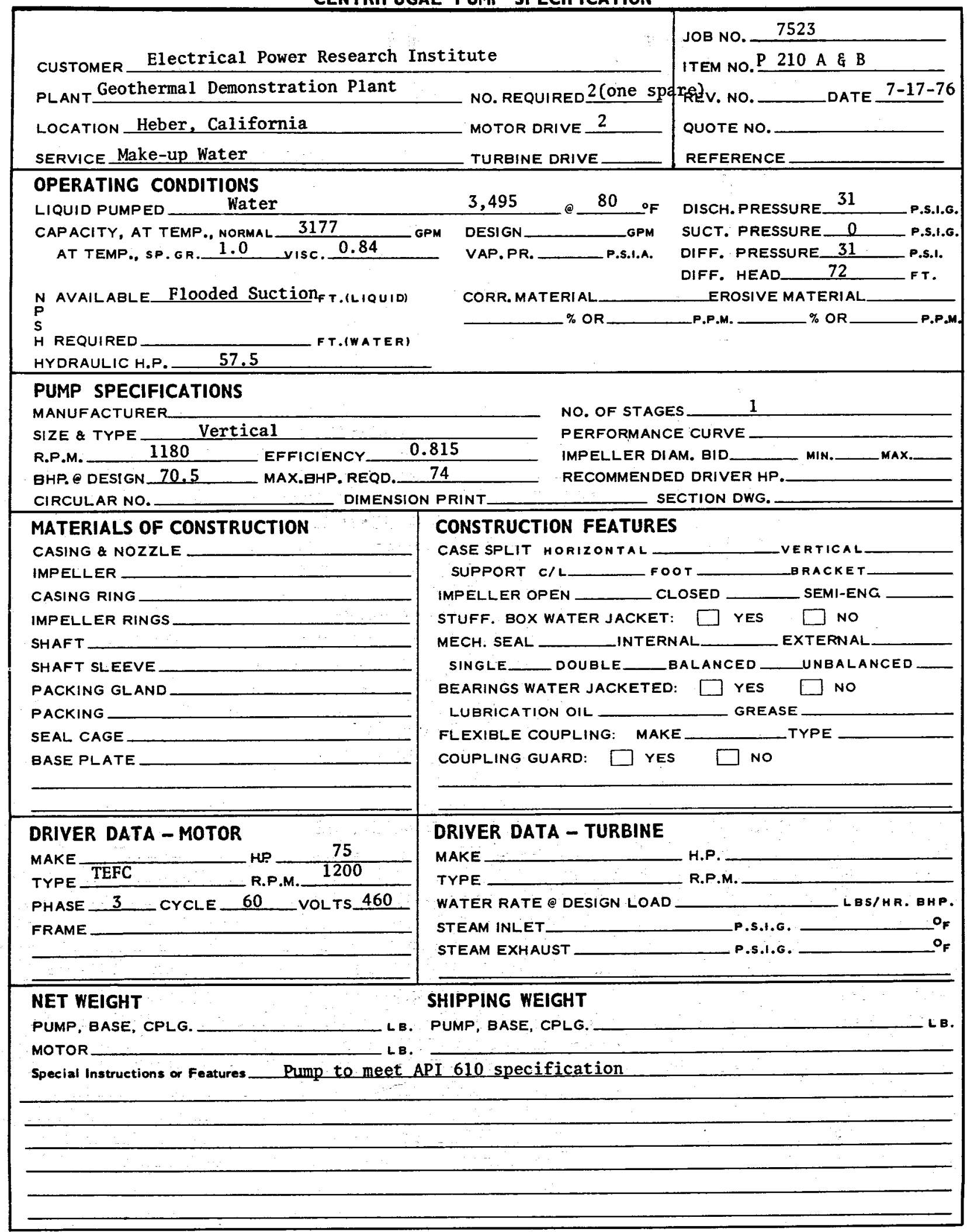




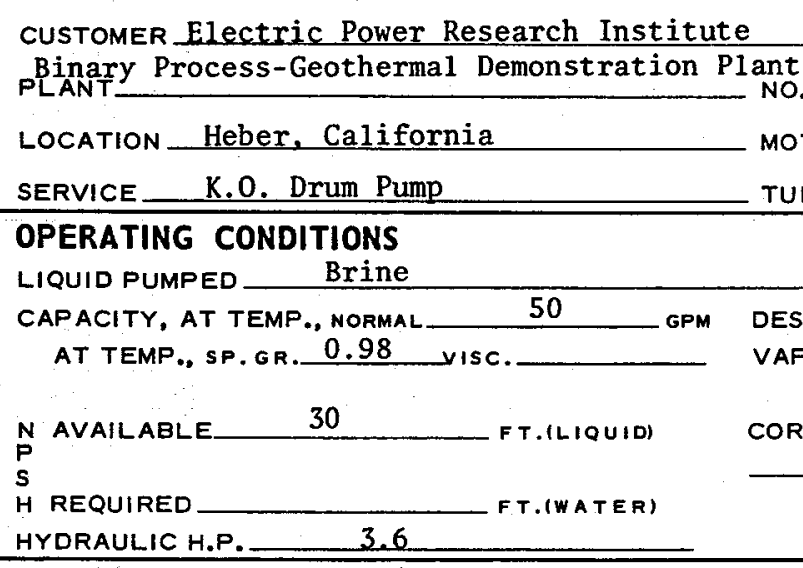

CUSTOMER Electric Power Research Institute

Binary Process-Geothermal Demonstration Plant

LOCATION Heber, California

SERVICE K.O. Drum Pump

\section{OPERATING CONDITIONS}

LIQUID PUMPED Brine

CAPACITY, AT TEMP., NORMAL

AT TEMP., SP.GR. 0.98 VISC.

$50 \quad$ GPM

N AVAILABLE FT.(LIQUID)
S
H REQUIRED
HYDRAULIC H.P. $\quad 30$
F.T.(WATER)

NO. REQUIRED One

MOTOR DRIVE $\mathrm{X}$

\section{PUMP SPECIFICATIONS}

MANUFACTURER

SIZE \& TYPE Horizontal

R.P.M. 3600 EFFICIENCY 34

BHP. DESIGN 10.6

MAX.BHP. REQD. 15 TURBINE DRIVE

TURBINE DRIVE

\begin{tabular}{|c|}
\hline DESIGN $50^{\circledR}$ \\
\hline P.PR. 3.7 \\
\hline
\end{tabular}

CORR. MATERIAL

$\%$ OR CIRCULAR NO. DIMENSION PRINT_ SECTION DWG.
NO. OF STAGES

PERFORMANCE CURVE

IMPELLER DIAM. BID

RECOMMENDED DRIVER HP.

\section{MATERIALS OF CONSTRUCTION}

CASING \& NOZZLE C. C. .

IMPELLER

C. I.

CASING RING

IMPELLER RINGS

SHAFT

Al1oy

SHAFT SLEEVE

PACKING GLAND

PACKING

SEAL CAGE

BASE PLATE C. S.

\section{DRIVER DATA - MOTOR}

MAKE HP $\quad 15.0$

TYPE TEFC

R.P.M. 3600

PHASE 3 CYCLE 60 VOLTS 460

FRAME

\section{NET WEIGHT}

PUMP, BASE, CPLG.

MOTOR

Special Instructions or Features

\section{CONSTRUCTION FEATURES}

CASE SPLIT HORIZONTAL

SUPPORT C/L.

FOOT CLOSED

VERTICAL

IMPELLER OPEN

STUFF. BOX WATER JACKET:
MECH. SEAL $X$ INTERNAL

RACKET

SINGLE DOUBLE_ BALANCED UNBALANCED

BEARINGS WATER JACKETED: $\square$ YES $\square$ NO

LUBRICATION OIL

GREASE

FLEXIBLE COUPLING: MAKE__ TYPE

COUPLING GUARD: $\square$ YES $\square$ NO

\section{DRIVER DATA - TURBINE}

MAKE

H.P.

TYPE R.P.M.

WATER RATE O DESIGN LOAD LES/HR. BHP. STEAM INLET__P.S.I.G. P_____ P.I.G. STEAM EXHAUST P.S.I.G. P_ P_ OPF SHIPPING WEIGHT LB. PUMP, BASE, CPLG. L. L早. Design Pump in accordance with API Snecification 610 
CUSTOMER Electric Power Research Institute

PLANT_ - _ _ D - NO. REQUIRED 3 Cone spa

LOCATION Heber, California

SERVICE Firewater

\section{OPERATING CONDITIONS}

LIQUID PUMPED Water

CAPACITY, AT TEMP., NORMAL 1500 GPM

AT TEMP., SP.GR. 1.0 VISC. $0.74 \mathrm{cp}$

N AVAILABLE $\quad 37$

P

H REQUIRED 87.5 FT.(WATER)

HYDRAULIC H.P.

\section{PUMP SPECIFICATIONS}

MANUFACTURER

SIZE \& TYPE Horizontal

R.P.M. 1770 EFFICIENCY 86\%

GHP. DESIGN 102 MAX.EHP. REQD. 118

CIRCULAR NO. DIMENSION PRINT

Diesel Engine ITUREINE/UFW/7 Two

DESIGN $1500 \quad 90 \quad$ OF
VAP.PR. GPM

CORR. MATERIAL \% OR

JOB NO. $\quad 7523$

ITEM NO. P-2002 (A-C)

NO. DATE $\underline{7-21-76}$

QUOTE NO.

REFERENCE

DISCH.PRESSURE 100 SUCT PRESSURE 0 P.S.I.G. 100 P.S.1.0. DIFF. EROSIVE MATERIAL P.P.M. $\% O R$ P.P.M.

MATERIALS OF CONSTRUCTION

CASING \& NOZZLE C C I

IMPELLER

CASING RING Bronze

IMPELLER RINGS

SHAFT Alloy

SHAFT SLEEVE

PACKING GLAND

PACKING Graphite Impreg ASB

SEAL CAGE

BASE PLATE

C - S S

\section{DRIVER DATA - MOTOR}

MAKE HP 125

TYPE TEFC R.P.M. 1770

PHASE 3 CYCLE 60 VOLTS 460

FRAME

\section{NET WEIGHT}

PUMP, BASE, CPLG.

MOTOR

Special Instructions or Features LB.

\section{CONSTRUCTION FEATURES}

CASE SPLIT HORIZONTAL SUPPORT C/L

NO. OF STAGES $\quad 1$ PERFORMANCE CURVE IMPELLER DIAM BID RECOMMENDED DRIVER HP. SECTION DWG.

FOOT
IMPELLER OPEN CLOSED

STUFF BOX WATER JACKET: $\square$ YES $\square$ NO $M E C H$. SEAL INTERNAL SINGLE_ DOUBLE_ BALANCED_UNBALANCED EXTERNAL BEARINGS WATER JACKETED: $\square$ YES $\square$ NO LUBRICATION OIL GREASE

FLEXIBLE COUPLING: MAKE TYPE COUPLING GUARD: $\square$ YES $\square$ NO

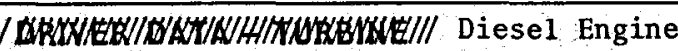

MAKE H.P. 125

TYPE R.P.M. $\quad 1770$

WATER RATE@ DESIGN LOAD

STEAM INLET

STEAM EXHAUST

P.5.1.6. LES/HR.BHP.

P.S.I.G.

\section{SHIPPING WEIGHT}

LB. PUMP, BASE, CPLG. LB. 
CENTRIFUGAL PUMP SPECIFICATION

CUSTOMER Electric Power Research Institute

Binary Process-Geothermal Demonstration PLANT

LOCATION Heber, Cali fornia

SERVICE

Firewater Jockey

OPERATING CONDITIONS

LIQUID PUMPED

CAPACITY, AT TEMP., NORMAL

AT TEMP., SP.GR. 1.0 vISC. $0.74 \mathrm{cP}$

\begin{tabular}{l} 
N AVAILABLE F T.(LIQUID) \\
P \\
S R REQUIRED \\
HYDRAULIC H.P. IWATER) \\
HYRA 1.2 \\
\hline
\end{tabular}

\section{PUMP SPECIFICATIONS}

MANUFACTURER

SIZE \& TYPE Vertical

R.P.M. 3500 EFFICIENCY $60 \%$

BHP. D DESIGN 2.0 MAX.EHP. REQD. CIRCULAR NO. DIMENSION PRINT

\section{MATERIALS OF CONSTRUCTION}

CASING \& NOZZLE C I I

IMPELLER Bronze

CASING RING "

IMPELLER RINGS "

SHAFT_A110Y

SHAFT SLEEVE

PACKING GLAND

PACKING

SEAL CAGE

BASE PLATE

\section{DRIVER DATA - MOTOR}

MAKE TYPE TEF H.P.M. $\quad 3500$

PHASE 3 C CYCLE 60 VOLTS 460

FRAME

\section{NET WEIGHT}

PUMP, BASE, CPLG.

MOTOR

Special Instructions or Features

MAKE

TYPE
JOB NO. 7523

ITEM NO. P-2003

REV. NO. DATE

QUOTE NO.

REFERENCE TURBINE DRIVE

DISCH.PRESSURE_ 100 P.S.I.G. SUCT. PRESSURE 0 P.S.I.G. DIFF. PRESSURE 100 P.S.I.

DIFF. HEAD_ 231 FT. EROSIVE MATERIAL $\%$ OR P.P.M. $\%$ OR P.P.M.

NO. OF STAGES 4 PERFORMANCE CURVE IMPELLER DIAM. BID MiN. _ MAX. RECOMMENDED DRIVER HP. SECTION DWG.

\section{CONSTRUCTION FEATURES}

CASE SPLIT HORIZONTAL SUPPORT C/L. FOOT VERTICAL IMPELLER OPEN CLOSED QRACKET STUFF. BOX WATER JACKET: $\square$ YES $\square$ NO MECH. SEAL _ $\mathrm{X}$ INTERNAL EXTERNAL SINGLE___ DOUBLE___ BALANCED _ UNBALANCED BEARINGS WATER JACKETED: $\square$ YES $\square$ NO LUBRICATION OIL _ GREASE FLEXIBLE COUPLING: MAKE _ TYPE COUPLING GUARD: $\square$ YES $\square$ NO

\section{DRIVER DATA - TURBINE} H.P. R.P.M.

WATER RATE @ DESIGN LOAD LES/HR. BHP. STEAM INLET________._. P. 
THE BEN HOLT CO.

COOLING TOWER SPECIFICATIONS

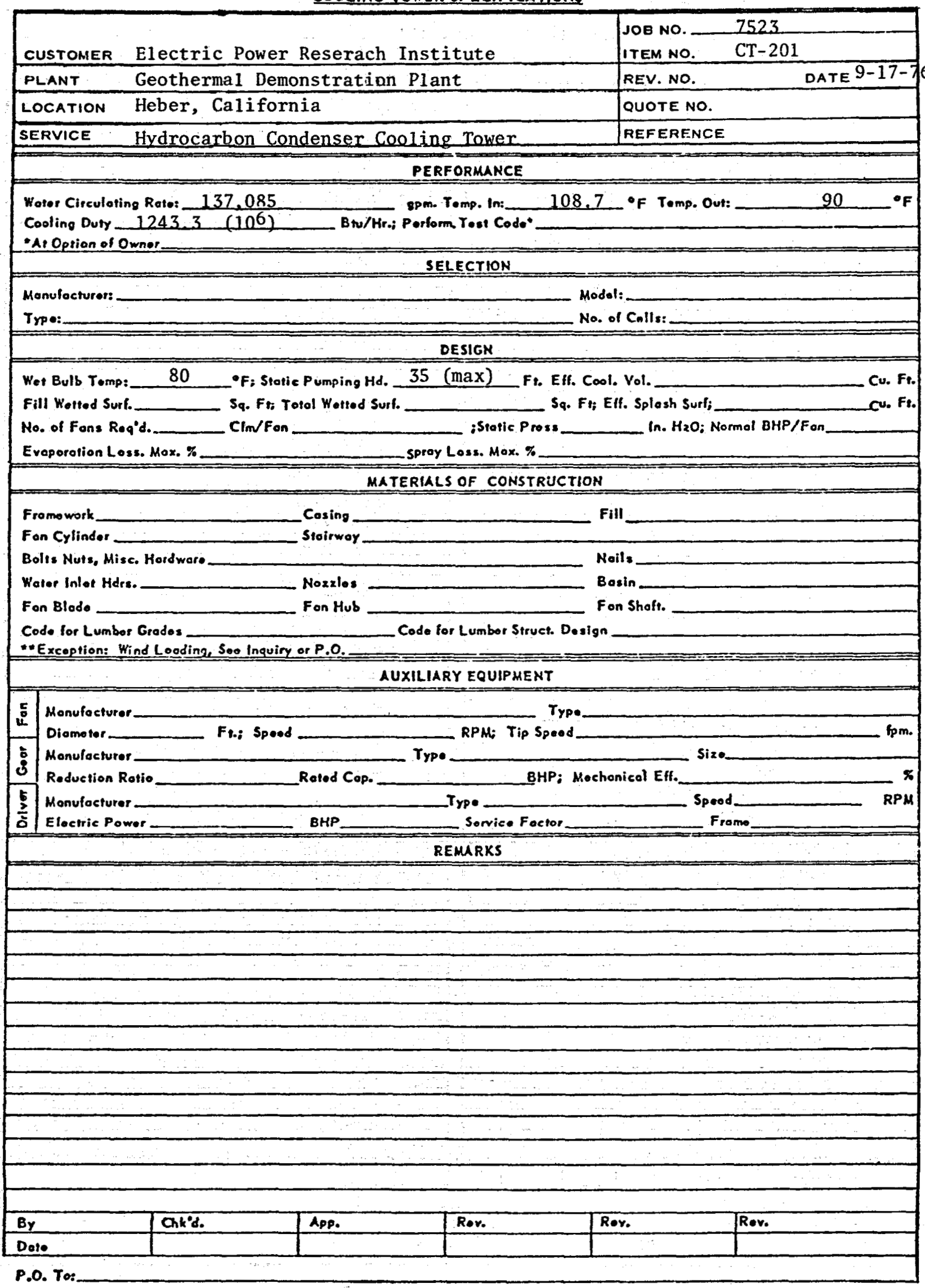


STANDARD DATA SHEET FOR RECIPROCATING COMPRESSORS

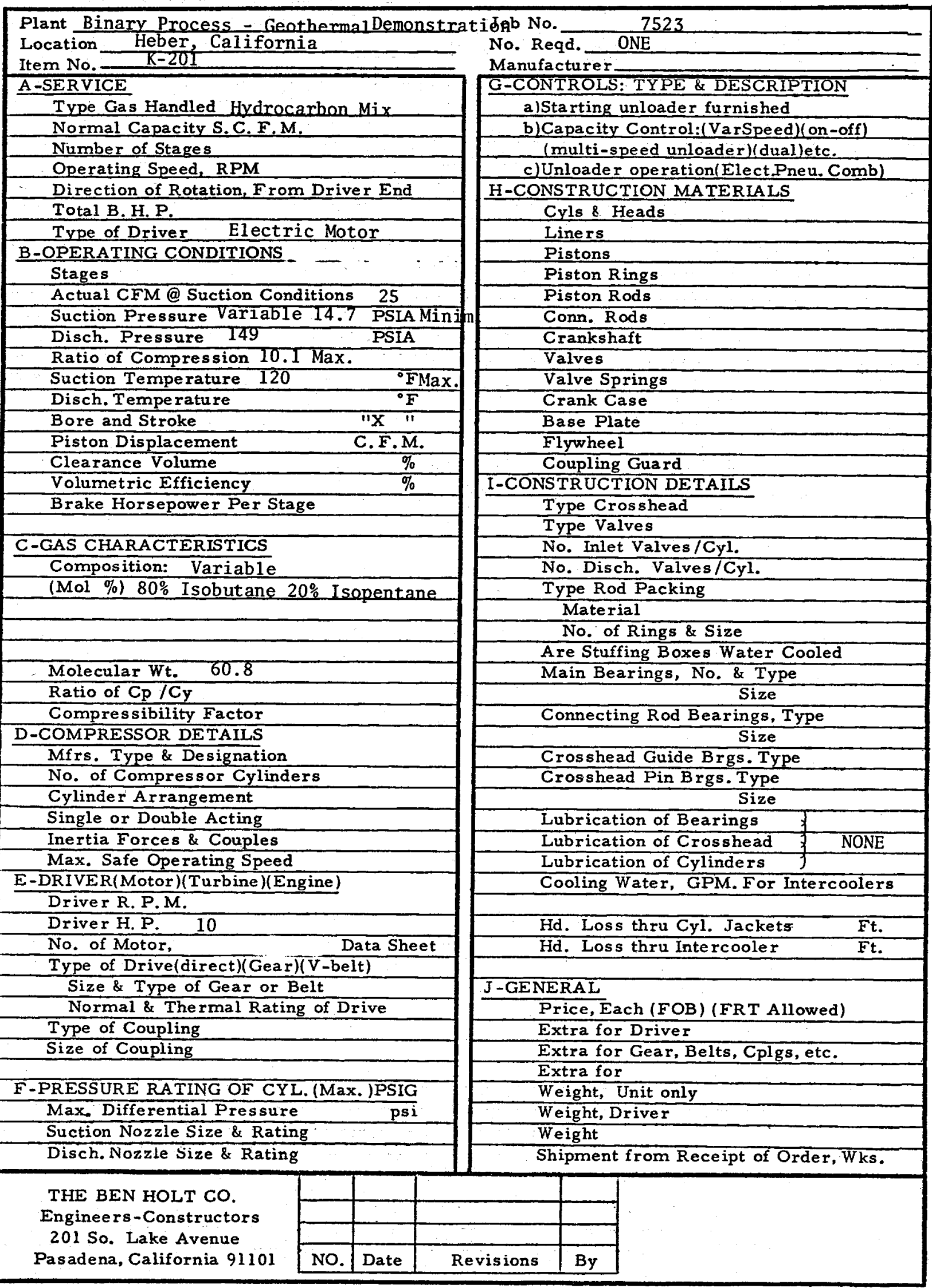


Electric Power Research Institute

Holt Job No. 7523

Palo Alto, California

March 1977

Geothermal Demonstration Plant

Page 1 of 23 Pages

\section{GENERAL REQUIREMENTS}

\section{SCOPE}

The manufacturer shall furnish one (1) hydrocarbon turbine-generator rated and equipped in accordance with these specifications. The manufacturer's proposal shall include in the quoted price freight to the rail siding nearest Heber, California. The manufacturer's proposal shall include in the quoted price the services of an engineer to provide technical direction of installation.

\section{REQUIRED EQUIPMENT}

Turbine

One hydrocarbon turbine rated as specified herein.

\section{Generator}

One totally enclosed hydrogen cooled synchronous generator rated $76.5 \mathrm{MVA}$, .85 power factor, 3 phase, 60 cycles, .58 short circuit ratio, and 13,800 volts. The generator shall be equipped with water to hydrogen type heat exchangers for cooling. Each generator shall be equipped with a nonrotating, brushless type exciter and automatic voltage regulator.

Turbine-generator shall be suitable for outdoor location.

\section{MATERIALS}

A11 of the casings and forgings used in the construction of this unit shall be of high quality. They shall have the necessary magnetic particle inspections, casting processings, radiographic testing, and sonic testing performed that are outlined in the currently applicable ASTM specifications.

\section{INSPECTION}

The Purchaser and the Purchaser's representative reserve the right to inspect fully all phases of the manufacture of the turbine and the generator to insure that the manufacturer is complying with the specifications. Any item found to be not in accordance with the specification will be rejected at no additional cost to the Purchaser. The Purchaser's inspection shall not relieve conformance to the specifications or release from warranty. 


\section{PREPARATIONS FOR SHIPMENT}

Preparation for shipment shall be in accordance with Section 8 of API Standard 617. Paragraphs 8.1.3, 8.1.4, and 8.1.5 of this standard shall not apply. The preparations for shipment of the lube and seal oil system shall conform to Section 5 of API Standard 614.

\section{LEGAL LIABILITIES}

A1l warranties, patent rights, tax liabilities, terms of payment, and other legal liabilities shall be clearly defined in the manufacturer's proposal.

\section{VARIATIONS}

Any variations from the requirements of this specification, because of manufacturer's standards, shall be clearly stated in the manufacturer's proposal. Any alternates in construction which the manufacturer may desire to offer shall be described in complete detail.

\section{TURBINE}

8. TYPE AND DESIGN REQUIREMENTS

The turbine, which sha11 be rated in accordance with the requirements of these specifications, shall be directly connected to and shall drive the generator described herein.

When in normal operation the unit and its associated equipment shall be sufficiently strong to withstand without injury, any strain that might result from sudden application or withdrawal of normal load, or from any transient speed to 120 percent of rated speed. The unit shall be designed to conform to all API mechanical specifications for equipment handling highly flammable fluids, i.e., API Standard 617.

A system torsional and lateral critical speed analysis shall be made.

The design flow requirements for the turbine at rated throttle conditions are as specified below: 
Electric Power Research Institute

Palo Alto, California

Ho1t Job No. 7523

Geothermal Demonstration Plant

March 1977

Page 3 of 23 Pages

Fluid

Flow Rate

Inlet Pressure

Design Pressure

Inlet Temperature

Design Temperature

Outlet Pressure

Efficiency

Rated Horsepower
$80 \%$ Isobutane, $20 \%$ Isopentane

$3,490,000 \mathrm{~kg} / \mathrm{hr}(7,687,000 \mathrm{lb} / \mathrm{hr})$

$3,450 \mathrm{kPa}$ (500 psia)

$4,480 \mathrm{kPa}$ (650 psia) and full vacuum

$146 \mathrm{C}(295 \mathrm{~F})$

$182 \mathrm{C}(360 \mathrm{~F})$

$498 \mathrm{kPa}(72.3 \mathrm{psia})$

$85 \%$

83,560

It will also be designed to be easily and inexpensively modified to meet the following requirements:

Fluid

Flow Rate

Inlet Pressure

Inlet Temperature

Outlet Pressure

Efficiency

Rated Horsepower
$10 \%$ Propane, 90\% Isobutane

$4,098,000 \mathrm{~kg} / \mathrm{hr}(9,027,000 \mathrm{lb} / \mathrm{hr})$

$4,067 \mathrm{kPa}$ (590 psia)

$140 \mathrm{C}(285 \mathrm{~F})$

$660 \mathrm{kPa}$ (96.1 psia)

$85 \%$

88,900

9. CONSTRUCTION AND FEATURES

\subsection{General}

All parts which are subject to temperature changes shall be designed and supported so as to permit free expansion and contraction in an effort to minimize harmful distortion or misalignment.

\subsection{Turbine Casings and Diaphragms}

Turbine casings sha11 conform to API Standard 617, Section 2.3 and Section 3. Provisions shall be made in the design of the turbine to control thermal stresses in the turbine casing. The main horizontal joint and/or the main vertical joint in the turbine she11 sha11 be metal to metal. The turbine shells and diaphragms sha11 be supported so that their movement relative to the shaft be minimized. Their design shall be made to minimize the time required for an inspection or a repair. A design which permits bearing inspection or removal without removal of the turbine shells is required. The casing shall be equipped with suitable drains. 


\subsection{Turbine Rotor}

The rotor shall be stiff-shaft type and conform to the requirements of the appropriate section of API Standard 617. The completed turbine rotor shall be balanced in the manufacturer's plant so as to run smoothly and without excessive vibration. After machining operation of the rotor, it shall be given a heat stabilization test to minimize thermal stresses. A grounding device shall be provided between the stationary and rotating parts of the turbine to prevent the flow of turbine shaft currents between the rotor and the bearings. Provision shall be made in the design of the rotor to minimize stress concentrations.

\subsection{Buckets (Axial Flow Turbines)}

The turbine buckets shall be securely and adequately anchored and shall be readily renewable. Welding of buckets to wheel disc will not be acceptable in any stage. The natural frequency of the buckets shall be such as to avoid resonant vibration at or near normal operating speed.

\subsection{Shaft Sealing}

A shaft sealing system shall be provided which will prevent the escape of hydrocarbon from the shaft ends and also prevent sealing oil from entering the turbine casing. The seals shall conform to Section 2.15 of API Standard 617. The seals may be either Labyrinth Type or Mechanical (Contact) Type as described in Paragraphs 2.15.3a and $2.15 .3 \mathrm{~b}$.

\subsection{Turbine Stop and Control Valves}

The unit sha1l be equipped with an emergency stop or throttle valve which will include provisions to actuate the main circuit breaker when the valve is closed and also provisions for testing while unit is in operation. It shall include a solenoid trip and signal switches to indicate the valve position. The valve shall be located in the proximity of the front of the unit or on the casing. Supports for the valve shall be supplied as well as piping to connect stop valve to turbine.

A removable corrosion-resistant integral strainer shall be furnished with the emergency valve with a temporary fine mesh strainer for startup. 
All of the valves, valve stems, and valve seats shall be made of corrosion and erosion-resistant materials which have been proven suitable for successful operation and durability in other existing applications.

\subsection{Turbine Governors}

An automatic speed governor shall be supplied which will regulate the flow to the turbine through a suitable governing mechanism. It shall prevent the unit from reaching the overspeed tripping point in the event of an instantaneous change in load from full to no load. The governor shall be furnished with a means of manually limiting the turbine-generator output. The governor shall be furnished with an adjustment for regulating the speed and/or load of the turbine-generator manually from a remote location.

In addition to the automatic speed governor, a separate quick acting emergency governor will be furnished that will cause flow to be shut off to the unit when it reaches approximately 10 percent overspeed, but can be reset when the speed is reduced to approximately normal, thus permitting the unit to be synchronized with other units. This governor shall be of a type which can be tested at no load.

9.8 Hydraulic, Lubrication and Seal Oil System

A complete hydraulic fluid system shall be furnished to provide hydraulic fluid to the turbine control valve gear and emergency trip system. This system may be combined with the lubricating oil and seal oil system.

A complete combined lubricating and seal oil system shall be provided to supply lubricating and seal oil to the turbine and generator. The major components of the system shall include:

Oil reservoir

Lubricating and seal oil pumps and drivers

Oil coolers

oil filters

Separate overhead seal oil tanks for the turbine and generator (for Labyrinth Type seals)

Seal oil traps

Control panel and instruments 
All system components shall be in accordance with the applicable sections of API Standard 614. Interpretation of this standard sha11 be as follows:

General - Paragraphs 2.1.2, 2.1.4, 2.1.7, and 2.1.9 of API Standard 614 sha11 not apply.

Oil Reservoirs - Paragraphs 2.2.6, 2.2.7, and 2.2.13 of API Standard 614 sha11 not apply.

Pumps and Drivers - Paragraphs 2.3.2 and 2.3.6 of API Standard 614 shall not apply. This system shall not utilize steam turbine drivers.

Coolers - Coolers shall be in accordance with Section 2.4 of API Standard 614.

Filters - Filters shall be in accordance with Section 2.5 of API Standard 614.

Overhead Tanks - Paragraph 2.7.4 of API Standard 614 shall not apply.

Seal Oil Drain Traps - Paragraph 2.9.1a of API Standard 614 shall not apply. The vent gas shall be piped to the turbine exhaust and the drain lines shall be piped to the oil reservoir.

Piping - Piping shall be in accordance with Section 2.11 of API Standard 614.

Controls and Instrumentation - Shall be in accordance with Section 3 of API Standard 614.

Drawings shall be provided in accordance with Paragraphs 6.1.2 and 6.1.5 of API Standard 614.

\subsection{Bearings}

Al1 bearings shall be designed for pressure lubrication and shall operate without injurious temperature rise or undue wear. It is preferred that all main bearings must be provided with a positive visual check point on oil flow through the bearings. Leakage of oil or oil vapors from the bearing housings must be minimized. 
Al1 radial bearings must be split to permit removal of the upper half for inspection and must be removable without removing the rotor. Radial bearings shall conform to Paragraph 2.13.1 of API Standard 617.

A thrust bearing shall be provided to maintain the correct axial relationship between the rotating and the stationary parts. The axial position of the turbine rotor must be adjustable when the unit is at rest. Thrust bearings sha11 conform to Paragraph 2.13.2 of API Standard 617.

\subsection{Vibration and Balance}

The turbine design and testing shall conform to Section 2.18 of API Standard 617.

Vibration and position detectors shall be provided in accordance with Section 2.14 of API Standard 617. Paragraphs 2.14.3 and 2.14.4 of this standard sha11 not apply.

\section{MOTORS}

10.1 All AC motors shall be in accordance with Specification No. 3600-2.

10.2 All wiring shall be in accordance with electrical components Specification No. 3600-3.

\section{ACCESSORIES}

In addition to those accessories already mentioned in these specifications, the following shall be included:

An electric type speed indicating device will be furnished consisting of a tachometer generator and an indicating instrument.

Industrail dial-type thermometers and wells shall be provided for all main bearings and thrust bearing oil drains and for the oil cooler outlet temperatures.

A thrust failure trip device shal1 be provided for both active and inactive sides of thrust bearing. 
A complete turning gear system shall be furnished with necessary interlocks to prevent the turning gear from operating until proper oil pressure has been established. Engagement of the turning gear at standstill shall be accomplished by hand.

Al1 special maintenance tools shall be furnished including sledging wrenches for bolts and nuts 1-1/2" and larger, eyebolts, casing guide pins, jacking bolts, turbine casing lifting slings, turbine rotor lifting slings, and other tools depending on special turbine construction.

Low hydraulic pressure alarm switch, piped and wired to a terminal board.

Turbine bearing low oil pressure alarm switch.

Soleplates are to be furnished.

Metal lagging for high temperature parts of the turbine and heat retention insulation for installation by the purchaser as follows:

Plastic insulation for upper and lower turbine shells and valve bodies.

A coupling for connecting the turbine and generator shafts shall be provided. The coupling shall be balanced.

Block insulation for stop valve flanges and flanges at the turbine she11.

Reusable blankets and/or block type insulation for the horizontal and vertical shell flange joints.

\section{GENERATOR}

12. TYPE AND DESIGN REQUIREMENTS

The generator shall be an alternating current synchronous generator, rated in accordance with the requirements of these specifications, and shall be directly connected to and driven by the turbine described herein. The generator shall be of the nonsalient pole revolving field type.

The telephone influence factors of the generator shall be in accordance with the latest ANSI and NEMA standards. 
The deviation factor of the open circuit terminal voltage wave of the generator shall not exceed 10 percent as defined by ANSI and NEMA standards.

The generator armature shall be capable of operating at 13 percent of rated armature current for at least one minute, starting from stabilized temperatures at rated conditions.

The generator field windings shall be capable of operating at a field voltage of 125 percent of rated load field voltage for at least one minute starting from stablized temperatures at rated conditions.

The generator will be capable of withstanding, without injury, the thermal effects of unbalanced faults at the generator terminals, including the decaying effects of field current (where protection is provided by causing field current reduction, such as with a field breaker or equivalent) and the d-c component of the stator current, for times up to 120 seconds, provided the integrated product $\left(\mathrm{I}_{2}{ }^{2} \mathrm{t}\right)$ of generator negative phase sequence current $\left(I_{2}\right)$ and time $(t)$ does not exceed 30 .

The generator shall be capable of withstanding without mechanical injury, any type of short circuit at its terminals for times not exceeding the short time thermal capabilities, when operating at rated KVA and power factor and five percent overvoltage, provided the maximum phase current is limited by external means to a value which does not exceed the mximum phase current obtained from the three-phase fault.

In the case of stator windings, the criterion for no injury is that the windings will satisfactorily withstand a normal maintenance high-potential test. There will also be no visible abnormal deformation or damage to the winding coils and connections.

The generator shall be suitable, for operation at rated KVA, power factor, and frequency at any voltage not more than 5 percent above or below rated voltage, but not necessarily in accordance with the standards of performance established for operation at normal rating.

The generator shall be capable of operating continuously at full load under unusual service conditions, (altitude $20 \mathrm{ft}$ and ambient temperature of $50^{\circ} \mathrm{C}$ as per ANSI standards). The total temperatures as determined by any of the methods given in ANSI standards shal1 not exceed $100^{\circ} \mathrm{C}$ for the stator coils and $125^{\circ} \mathrm{C}$ for the field when operating at full load or below. The stator and rotor insulation shall be Class $F$. 


\section{CONSTRUCTION AND FEATURES}

\subsection{Stator}

The stator coils shall be insulated with multiple layers of mica tape and compounded to eliminate any voids so as to form a long lasting and durable insulation of the stator coils. Insulation of stator core laminations shall be nonaging and of a type which will maintain its insulating properties at high temperatures.

Leads from both ends of all phase windings shall be brought out to an accessible location.

\subsection{Rotor}

The generator rotor shall be machined from a solid forging.

Rotor retaining rings shall be protected from damage due to single phase or unbalance loads and be free of contact with the rotor body.

\subsection{Bearings}

All bearings must be split to permit removal of the upper half for inspection. Bearings will be provided with a positive visual check point on oil flow through the bearings.

Under normal operating conditions the maximum amplitude of vibration as measured on the bearing cap, shall not exceed $1 \mathrm{mil}$. The maximum amplitude of vibration on the stator frame except for the end shields shall not exceed $1-1 / 2$ mils vibration.

Bearings shall be insulated where necessary to prevent the flow of "shaft current".

\subsection{Generator Cooling System}

The generator shall be equipped with finned tube surface gas coolers with suitable surface area to maintain the generator within the operating range. The coolers shall be of sufficient size and number so that the unit may operate at a minimum of 80 percent rated KVA with one cooler section out of service. The gas coolers shall be arranged in four sections and shall be mounted in the generator 
housing in such a manner as will permit removal from service for cleaning of any one section when required without shutting down the generator. Cooler tubing material shall be 90-10 copper nickel. Maximum cooling water temperature is $32 \mathrm{C}(90 \mathrm{~F})$.

\section{ACCESSORIES}

In addition to those accessories already mentioned in the specifications above, the following shall be included:

Steel oil piping shall be provided to the main bearings to the requirements set forth in a previous paragraph.

Industrial dial-type thermometers and wells shall be provided for main bearing oil drains.

The generator shall be equipped with six temperature detectors embedded in the stator windings, four temperature detectors in the gas cooler outlets, and four in the gas cooler inlet.

Special wrenches for all special bolts and nuts and lifting equipment for the generator rotor shall be furnished, including a rotor lifting sling and rotor skid with shims.

Sole plates are to be furnished.

\section{EXCITER}

15. TYPE

The exciter shall be of the nonrotating type and rated in accordance with the requirements of these specifications. The exciter shall supply generator field excitation by utilizing power from the armature terminals of the generator. The excitation system shall regulate and maintain the desired terminal voltage as specified herein. The excitation system shall consist of power transformers, rectifiers, and excitation controls.

16. CONSTRUCTION AND DESIGN CONSIDERATIONS

The exciter shall be wide range stablized to permit stable operation down to 25 percent of rated exciter voltage on manual control. The exciter 
ceiling voltage as defined by ANSI manual standards will be at least 120 percent of rated voltage when operating with a load resistance equal to the generator field. The exciter shall be capable of supplying ceiling excitation under load for at least one minute. The rate of response of the exciter as defined by ANSI standards will be at least 0.5 . The response ratio will be 0.5 for an error signal of 10 percent. Terminal voltage shall be held within -0.5 percent no load to full load at rated voltage.

\section{TESTS}

17. TESTS

The following listed tests shall be performed on the unit and its components to insure that the startup of the unit can be accomplished with a minimum of testing at the work site.

\subsection{Turbine}

The following tests sha1l be made:

Test of oil pumps.

Test auxiliary oil pump regulator, if applicable.

Speed governor test and adjustment.

Emergency overspeed governor test and adjustment.

Stop valve or throttle valve test.

Balance of turbine rotor and operation of turbine rotor to 110 percent of rated speed for at least three minutes.

Assembly of turbine.

Physical and chemical analysis of major rotating parts.

Heat stabilization of rotor.

U1trasonic test on rotor.

Magnafluxing of buckets and rotor.

Hydrostatic test of high pressure turbine casing. 
Electric Power Research Institute

Holt Job No. 7523

Palo Alto, California

March 1977

Geotherma1 Demonstration Plant

Page 13 of 23 Pages

17.2 Generator

Mechanical Inspection.

Mechanical balance and high speed run to 110 percent of rated speed.

Measurement of cold resistance of armature and field windings.

Di-electric tests:

Armature - The standard test voltage shall be an alternating voltage whose effective value is $1,000 \mathrm{~V}$ plus twice the rated voltage of the generator. Test shall be applied for 60 seconds duration.

Field - The standard test voltage shall be an alternating voltage whose effective value will be ten times the field rated excitation voltage but not less than $1,500 \mathrm{~V}$. The test shall be applied for 60 seconds duration.

Air leakage test of stator frame.

Resistance temperature detector tests.

Physical and chemical analysis of major rotating parts.

U1trasonic test and magnafluxing of rotor.

\subsection{Static Exciter}

Trans formers

DC resistance of a11 windings.

Voltage ratio test.

Polarity test.

Exciting current.

High potential tests on windings at 60 hertz.

Induced potential test at twice operating voltage for not less than 400 cycles. 
Electric Power Research Institute

Holt Job No. 7523

Palo Alto, California

March 1977

Geothermal Demonstration Plant

Page 14 of 23 Pages

Rectifiers

Voltage drop at reduced current.

Reverse leakage test.

General

Voltage regulator gain test.

High potential tests on all circuits to ground.

Test to insure operation of all services associated with the excitation system.

VI DATA AND INFORMATION TO BE SUBMITTED IN PROPOSALS

18. GENERAL

Each manufacturer shall furnish, in his proposal, all the complete data to fully describe the equipment proposed. The data shall include, but not be limited to, the following information and all items must be fully covered in a complete manner.

\subsection{Combined Turbine-Generator Unit}

Dimensioned outline prints of the turbine-generator unit, giving approximate weights on the foundation and showing main piping connections.

A list of all accessories shall be furnished. This shall include all accessories required by these specifications.

A list of turbine, generator, and exciter tests.

Manufacturer's comments, interpretations, and exceptions to this specification.

Manufacturer's experience or installation list of units similar to the type required by this specification. 


\subsection{Turbine}

Guaranteed hydrocarbon rates at 100 percent load point, and an estimate performance curve for 0 percent - 105 percent of full load.

Description of the type of turbine rotor construction.

Description of the type of inlet valve gear and advise approximate number of valves included in each set of gear.

Description of turbine shaft sealing system.

Description of method of fastening blades to turbine wheels or fabrication of impellers.

Description of lubrication and hydraulic oil system.

Description of the control system.

Description of the turbine stop valve.

Description of emergency trip system.

Description of emergency overspeed governor.

\subsection{Generator}

The following curves for the generator size and rating specified herein.

Typical saturation and synchronous impedance curves.

Typical reactive capability curves.

Typical excitation "Vee" curves.

Transient and subtransient reactances.

Required cooling water flow rate at $95^{\circ} \mathrm{F}$ maximum cooling water temperature.

Description of method of cooling stator and rotor. 
Electric Power Research Institute

For hydrogen cooled generators, description of hydrogen cooling system, and shaft seals.

18.4 Exciter

Description of excitation system and each major component.

Nominal excitation rating, voltage, and amperes.

List of devices which must be mounted by Purchaser.

\subsection{Fill in Data}

Manufacturers shall answer all questions as briefly as possible. These shall represent their best judgement as to what is proposed in the manufacturer's design. This is not meant to restrict the successful bidder to supplying a final design in all details as filled in on this sheet. It is meant primarily to compare bids for evaluation purposes.

Manufacturer

Overall dimensions and weights (approx.)

Length (above floor)

Width

Height above floor

Minimum distance required from floorline to CL crane hood to lift largest piece.

During erection

(Specify which piece)

After erection

(Specify which piece)

How far forward from front end of turbine below floor does oil tank extend? 
Electric Power Research Institute

Palo Alto, California

Geothermal Demonstration P1ant

Does purchaser have flexibility

in locating oil tank below floor?

If (Yes) what are approximate

limitations?

What are the pulling dimensions from CL

of generator for removing generator field?

Straight pull

Canted

Approximate box dimensions of components

0il Tank (including oil coolers)

Seal oil control unit (if applicable)

$\mathrm{H}_{2}$ cabinet (if applicable)

Excitation cubicle

Assembled weight of turbine complete without external accessories

Shipped assembled

Assembled weight of generator complete without external accessories

Stator weight

Shipped assembled

Weight of turbine rotor

Weight of generator rotor

Heaviest piece and weight to be handled during erection

Heaviest piece and weight to be handled after erection
Holt Job No. 7523

March 1977

Page 17 of 23 Pages 
18.6 Turbine-Generator Features (Approximate Data)

Type of turbine

Impulse

Reaction

Combination impulse-reaction

Number of stages

Stop or Trip Throttle Valves:

Number

Where located

Casing

Method of support

Material

Number of inner she11s

Methods employed in construction

and/or operating procedures to

reduce thermal stresses

Size of openings:

Inlet

Exhaust

Turbine rotor

Material

Built-up wheels, solid, or combination

Blading fastening method 
Electric Power Research Institute

Holt Job No. 7523

Palo Alto, California

March 1977

Geotherma1 Demonstration Plant

Page 19 of 23 Pages

Blading material

Banding of blading (yes or no)

Stationary hydrocarbon path

Blade rings or diaphragms

Nozzle material

Method of support

Type of interstage seals

Shaft Sealing System

Type of system

Sealing Fluid

Bearings

Number of journal bearings

Turbine

Generator

Type of journal bearings

Type of thrust bearing

Dummy piston required

Yes

No

If dummy piston required, is there provision to move rotor axially under load Yes

No

Are sight flows provided

Yes

No

Oil System

Capacity of oil tank (gals) 
Electric Power Research Institute

Palo Alto, California

Geotherma1 Demonstration Plant
Holt Job No. 7523

March 1977

Page 20 of 23 Pages

Number and type of pumps on oil tank

Type of main pump

What provisions for isolating oil tank from $\mathrm{H}_{2}$ shaft sealing system

Are pressurized oil feedlines guarded (yes or no)

\section{Oil Coolers}

Number

Total cooling capacty $(\%)$

Tubing diameter and thickness

Tubing material

Required cooling water flow rate at $35 \mathrm{C}(95 \mathrm{~F})$ max. temperatures

Governing

Type of system

Manufacturer

Maximum predicted speed under rejection of maximum load

Can emergency governor be tested

Yes

No 
Electric Power Research Institute

Holt Job No. 7523

Palo Alto, California

March 1977

Geotherma1 Demonstration Plant

How is generator core mounted?

Number of generator coolers

How mounted

$\%$ load with one cooler out of service

Type of $\mathrm{H}_{2}$ seal (if applicable)

Can bearings be inspected without

removal of $\mathrm{H}_{2}$ (if applicable)

Armature winding material

Armature slot material

Method of fastening end turns of armature bars

Method of balancing generator rotor

Armature slot wedge material

Rotor wedge material

Generator Reactances

Zero sequence at rated current $x_{0}$

Negative sequence at rated voltage $X_{2}$

Subtransient at rated voltage $X^{\prime \prime} d$

Transient at rated current $X^{\prime} d$

Synchronous at rated current Xd 
Electric Power Research Institute

Holt Job No. 7523

Palo Alto, California

March 1977

Geothermal Demonstration Plant

SCR at rated KVA

Total generator loss excluding bearings

$\mathrm{KW}$

Generator efficiency at rated KVA and rated power factor

$\%$

Generator regulation at rated KVA and rated power factor

$\mathrm{H}_{2}$ consumption @ $206 \mathrm{kPa}$ (30 psia),

$\mathrm{H}_{2}^{2} 98 \%$ purity

Guaranteed cu.ft./24 hours

Expected cu.ft./24 hours

$\mathrm{H}_{2}$ required to fill to $30 \mathrm{psig}$ after purging

$\mathrm{cu} . \mathrm{ft}$.

$\mathrm{CO}_{2}$ required to scavenge $\mathrm{H}_{2}$ cu.ft.

purge air cu.ft.

Generator field current at maximum excitation

18.7 Installation Data

Will turbine be shipped assembled

Yes No

Will generator be shipped assembled

Yes No

Will oil tank and coolers be shipped assembled

Yes No

Are electrical connections made up to junction boxes at the factory or in the field

What portion of oil piping is prefabricated in the factory 
Electric Power Research Institute

Holt Job No. 7523

Palo Alto, California

March 1977

Geotherma1 Demonstration P1ant

Page 23 of 23 Pages

What portion of the hydrocarbon piping is prefabricated in the factory

What portion of seal oil piping is prefabricated at the factory (if applicable)

$(\%)$ 